UFS - Mestrado em Ensino de Ciências e matemática

Disciplina: O Ensino Experimental em Ciências Naturais

Docente: Prof. Dr. Luiz Adolfo de Mello

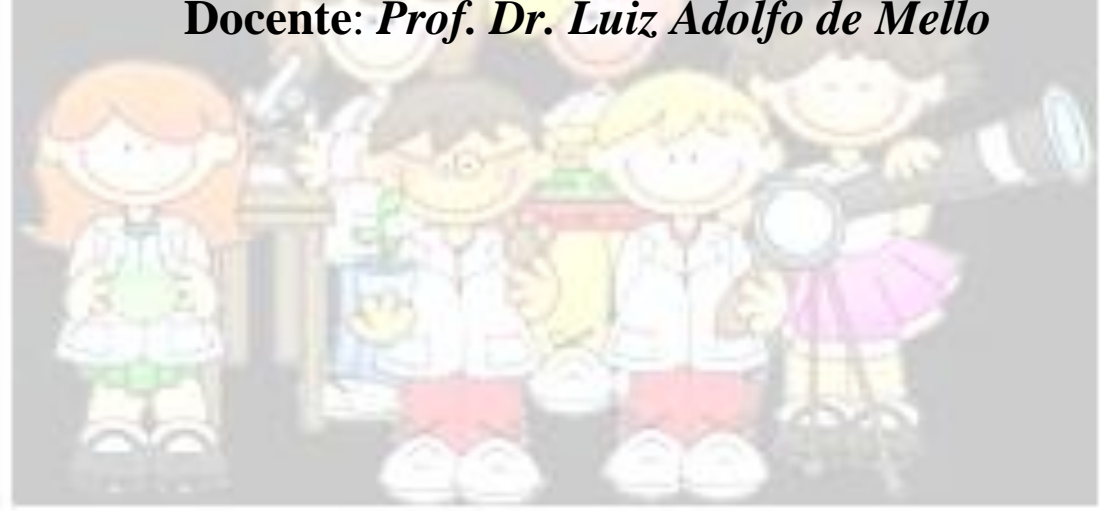

ENIERWWEWTACAC, ICGCS ESWHLLACOES

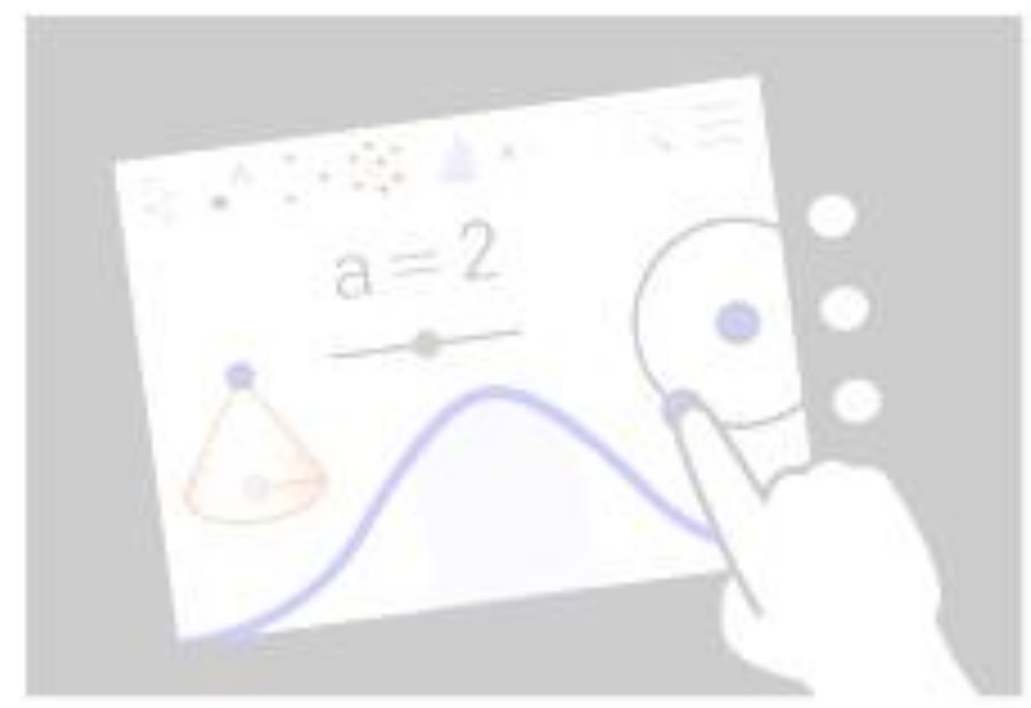




\title{
e-Ciências - O Ensino Experimental em Ciências Naturais
}

\author{
Elaboração de Conteúdo
}

Prof. Dr. Luiz Adolfo de Mello

Copyright (c) 2011, Universidade Federal de Sergipe / CESAD.

Nenhuma parte deste material poderá ser reproduzida, transmitida e gravada por qualquer meio eletrônico, mecânico, por fotocópia e outros, sem a prévia autorização por escrito da UFS.

Ficha catalográfica produzida pela Biblioteca Central Universidade Federal de Sergipe

\section{UNIVERSIDADE FEDERAL DE SERGIPE}

Cidade Universitária Prof. "José Aloísio de Campos"

Av. Marechal Rondon, $\mathrm{s} / \mathrm{n}$ - Jardim Rosa Elze

CEP 49100-000 - São Cristóvão - SE

Fone(79) 2105 - 6600 - Fax(79) 2105- 6474 


\section{INDICE - 0 ENSINO EXPERIMENTAL EM CIÊNCIAS NATURAIS}

AULA 1 - Cinética Química: Uma Abordadem Qualitativa

AULA 2 - A Existência do Oxigênio.

AULA 3 - Doluição Atmosférica-Ensino Experimental

AULA 4-Reações Ácido - Base

AULA 5-Determinacâo da Área de Ređióes Desmatadas.

AULA 6-Dolímeros em Ação

AULA 7 - Tensão Superficial

AULA 8 - Estudo De Associação De Resistores 74

AULA 9-Fermentação 


\title{
1 - Cinética Química : Uma abordagem qualitativa
}

\author{
Mestrandos : Marcos Mendonça Lemos e Robson Fágner Ramos de Araújo
}

Planejamento

- Abordar a cinética química com questionamentos do cotidiano

- Faríamos a experimentação

- Voltaríamos as perguntas do questionamento

- Breve histórico da cinética Química

- Abordagem de mais um experimento - Permanganato de potássio na glicerina

- Considerações e conclusões

\section{$1^{\text {a }}$ Etapa: CONCEPÇÕES PRÉVIAS}

Para que serve a geladeira?

E melhor tomar um comprimido ou uma solução para melhorar logo de alguma doença?

Por que quando vamos acender uma churrasqueira e melhor colocar o carvão triturado do que inteiro?

Por que quando queremos gelar os refrigerantes para uma festa e melhor colocar o gelo picado ao invés do gelo inteiro?

Para que serve o prazo de validade existentes nos alimentos? será que é verdade aquilo?

$2^{\mathrm{a}}$ Etapa: Experimentos primeira parte

Comprimidos efervescentes inteiros num copo com água quente e outro com água da torneira

Comprimidos efervescentes um inteiro e outro triturado na mesma temperatura

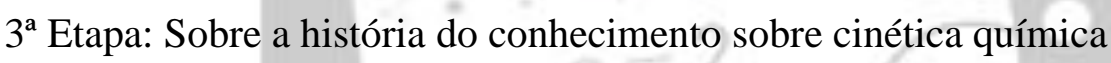

\section{$1^{\circ}$ texto: "Um breve histórico sobre Cinética Química"}

Um dos objetivos da Química é o de compreender os fatores e leis que influem na velocidade ou "rapidez" das transformações químicas, assim como os eventos microscópicos que se desenrolam durante essas transformações.

Através desse conhecimento, é possível hoje controlarmos a velocidade das transformações químicas tornando-as rápidas quando o objetivo for obter maior rendimento num processo, ou lentas quando oferecem riscos de acidentes, por exemplo.

O ramo da Química dedicado a este estudo denomina-se Cinética Química (do grego kinetiké, que significa "movimento"), o qual se desenvolveu a partir de meados do sec. XIX, graças ao trabalho árduo de vários cientistas que em meio a tantos erros e acertos, ajudaram a construir esta tão importante área da ciência.

Ludwig Wilhemy (1850) foi o primeiro cientista a investigar a rapidez de uma reação ao estudar a hidrólise da sacarose em meio ácido e acompanhando o progresso da mesma por meio de um polarímetro (figura 01). 


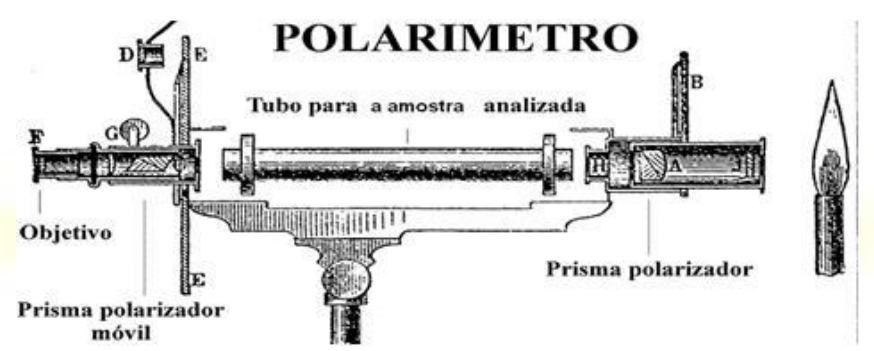

Representação do polarimetro

Figura 3. Representação do funcionamento de um polarímetro. A medição da chamada "atividade ótica" é feita em um aparelho chamado "polarímetro", usado para moléculas em solução. O aparelho é formado por uma fonte de luz (1), um filtro polarizador fixo (2), um tubo (3) contendo a amostra (4) e um filtro polarizador para análise (6), que ao ser girado registra o sentido levógiro (-) ou dextrógiro (+) e o ângulo em graus (de 0 a 180). Observe na figura o desvio do plano ao sair a luz do compartimento da amostra (5).

Nesse estudo, ele utilizou diversos ácidos em diferentes concentrações, variando as quantidades de açúcar e trabalhando em diversas temperaturas e chegou a uma expressão matemática que representa a rapidez de uma transformação química, hoje interpretada como: $\mathbf{V}$ $=\mathbf{K}$ [reagentes], em que K é uma constante. Em 1860, Williamsom veio contribuir ainda mais nesse sentido, afirmando: "Se uma transformação química se realizar em um determinado intervalo de tempo, no sentido de formação dos produtos e estes, por sua vez, interagirem reconstituindo os reagentes, haverá um momento em que as duas transformações ocorrerão com a mesma rapidez, estabelecendo entre elas um equilíbrio".

Berthelot e Péan de Saint-Gilles (1862-1863) estudando a esterificação entre um ácido e um álcool, observaram que essa transformação "parava" em um dado instante e que por esta razão nunca se completava pois aproximava-se de um "limite' que correspondia ao "equilíbrio". Em 1884, o químico holandês Jacobus Henricus van't Hoff (1852-1911) publicou o livro "Études de dynamique chimique" que foi considerado uma das mais importantes obras de química de todos os tempos. Neste livro ele aborda vários temas e os correlaciona com dados experimentais que já existiam na literatura. Devemos a van’t Hoff a introdução dos conceitos de ordem de reação, constante de velocidade, constante de equilíbrio, as duas setas opostas, natureza dinâmica do equilíbrio, efeito da temperatura e pressão no equilíbrio, e com relação ao efeito da concentração na velocidade de uma transformação química, van't Hoff estendeu e generalizou a análise matemática feita por Wilhemy. Criou também, juntamente com F.W. Ostwald (1853-1932; Prêmio Nobel de Química em 1909) e S.A. Arrhenius (1859-1927; Prêmio Nobel de Química em 1903), uma nova disciplina: a Físico-Química. Os três e seus estudantes encarregaram-se em divulgar a importância e a utilidade dessa área, que graças a eles cresceu e prosperou. 
Jacobus Henricus van't Hoff foi o primeiro cientista a receber o Prêmio Nobel de Química, em 1901. Uma merecida homenagem a um dos químicos mais influentes do seu tempo.

\section{$2^{\circ}$ texto: Um breve histórico sobre cinética química”}

$\mathrm{Na}$ aula anterior, ao estudarmos o primeiro texto e a evolução dos eventos que permitiram o desenvolvimento da cinética química, vimos que o primeiro polarímetro foi construído por Biot em 1812 e que em 1850, Wilhemy utilizou um polarímetro para investigar pela primeira vez a velocidade de uma transformação química, no caso, a hidrólise da sacarose. Este episódio consagrou a cinética como campo de estudo da química, pois até então, ela era estudada apenas em física.

Wilhemy estudou como a concentração do açúcar e a temperatura, na qual ocorria a reação, podiam interferir na sua velocidade e o enfoque da sua pesquisa, como de todas as pesquisas de sua época, era empírico-matemático (ou empírico-indutivista), ou seja, a partir da observação o cientista induzia uma comprovação experimental e a partir dos dados experimentais obtidos elaboravam-se hipóteses que depois se tornavam teorias ou leis, dependendo do número de provas por detrás da idéia. Tais teorias ou leis eram descritas matematicamente e desta forma $o$ desenvolvimento da ciência acontecia de forma contínua, acumulativa, as conclusões eram definitivas e o homem construía o próprio conhecimento.

Hoje sabemos que a ciência progride por dedução (método racionalista) e está voltada para a identificação, investigação e resolução de problemas. O progresso é caracterizado como uma "problemática progressiva" de uma tentativa teórica para outra.

A experimentação serve apenas de suporte a favor ou contra as hipóteses formuladas e nem toda investigação permite a realização de experiências devido ao custo, perigo, ética ou outras implicações.

Em 1867, Pfaunder sugere pela primeira vez uma explicação da velocidade em nível molecular, alegando que apenas as moléculas com maior energia, poderiam sofrer algum tipo de transformação.

A partir do séc. XX os estudos de cinética passaram a enfocar as transformações químicas em nível microscópico a fim de explicar o comportamento das moléculas durante essas transformações.

\section{$4^{\mathrm{a}}$ Etapa: Discutindo conceitos}

- Temperatura

- Superfície de contato

- Concentração de reagentes

- Energia de ativação

- Catalisadores

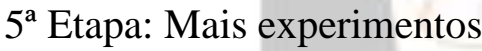

Alcool liquido num pires produzindo chama

Comprimido de permanganato de potássio com gotas de glicerina

$6^{\mathrm{a}}$ Etapa: Conclusões e considerações

$7^{\text {a }}$ Etapa: Aplicação de um questionário 
SEQUÊNCIA DIDÁTICA: o princípio das reações de combustão e conservação da matéria a partir de um enfoque histórico.

\section{Desenvolvimento da Sequência}

\section{PARTE 1}

\section{1 - Atividade Experimental: A controvérsia Histórica.}

Objetivo: Discutir algumas evidências experimentais que levaram a controvérsias históricas em torno da existência do oxigênio.

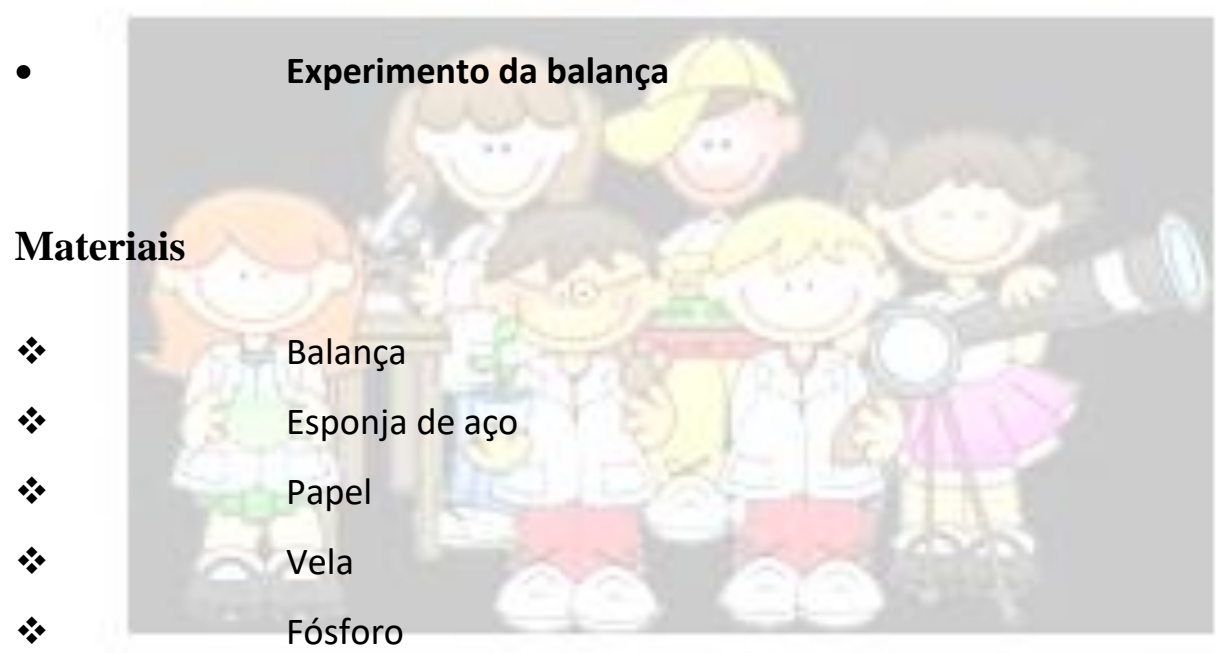

\section{Procedimento}

\section{Parte A}

$1-$

Construa uma balança, como a da figura.

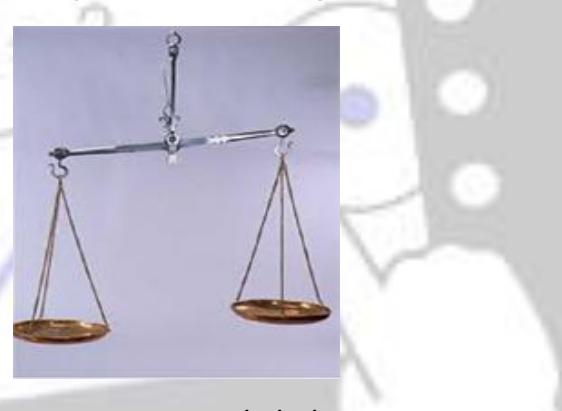

Figura 1: Esquema da balança 
sua massa.

\section{Parte B}

1- $\quad$ Coloque em cada prato um pedaço de palha de aço e estabilize a balança.

2Ponha fogo na palha de aço.

3Observe a combustão e anote o que aconteceu com a palha de aço e com sua massa.

\section{Perguntas investigativas}

$1-$

O que aconteceu com a massa do papel após a combustão? Como você

explica este acontecimento?

2-

O que aconteceu com a massa da palha de aço após a combustão? Como você explica este acontecimento?

3-

O que diferencia o experimento A com o experimento B? Explique.

4-

O que deve ter contribuído para a variação das massas do papel e da

palha de aço?

5-

Imaginando que as duas reações sejam realizadas em recipientes fechados, explique o que aconteceria com as massas dos sistemas.

\section{2-}

\section{Perguntas Problematizadoras}

$1-$

Na época que a lei de Lavoisier foi registrada, muitos químicos chegaram a duvidar de sua validade, pois havia observado que na queima de algumas substâncias, havia aumento de massa, enquanto que em outras havia diminuição. Como você explicaria este fenômeno.

2-

O corpo humano é constituído por, pelo menos, cerca de 60 produtos químicos diferentes, muitos dos quais são desconhecidos no próprio organismo. Todos nós sabemos a importância da água para a vida e $60 \%$ do peso corporal é água. O oxigênio ocupa o primeiro lugar na lista e faz-se $65 \%$ do corpo. Como poderíamos explicar a diferença entre a massa de um corpo vivo e um corpo morto?

3- No século XVIII Lavoisier e outros químicos compreendiam que durante a respiração um fluído elástico passava pelos corpos. Considerando as trocas gasosas que 
ocorrem durante a respiração, quais substâncias estariam relacionadas a este fluído? A respiração pode ser considerada uma reação de combustão?

4- Os cientistas do século XVIII desconheciam a composição do ar atmosférico, mas por meio da realização de experimentos sobre combustão, observaram que o ar sofria alterações. Para diferenciar esses tipos de ares, foi criada uma classificação: ar puro, para ar atmosférico, ar vital, para o ar absorvido na combustão e ar fixo para o ar que não participava da reação. Você conhece os gases que compõem o ar atmosférico? Quais gases estão relacionados ao ar vital e ao ar fixo?

Q - Como eles chegaram a conclusão de que o fluido possui propriedades de elasticidade?

3 - Texto: $O$ contexto histórico e as hipóteses da existência de um novo gás.

Apresentar de forma breve, algumas das discussões históricas em torno do experimento anterior.

O pensamento ocidental da antiguidade traz consigo discussões filosóficas sobre o desenvolvimento científico, que conquistou espaço ao longo dos anos. A ciência não é feita da noite pro dia, vários pensamentos surgem até que seja montada uma estrutura teórica, baseado em experiências ou não, no caso deste último a linguagem matemática. Durante o século XVIII vários personagens fizeram parte desta época tão marcante para a sociedade. Célebres acadêmicos como Georg Ernst Stahl (1660-1734), Carl Wilhelm Scheele (1742-1786), Joseph Priestley (1733-1804) e Antoine Laurent Lavoisier (1743-1794).

A descoberta do oxigênio foi um dos maiores triunfos da ciência, e todos os cientistas citados acima tiveram sua contribuição para desvendar todos os mistérios desse gás. De início ele foi chamado de flogisto, assim nomeado pelo Ernst Stahl, onde afirmava que toda substância que ardia continha um princípio combustível, que ao ser queimado liberava o gás flogisto. Scheele reforçou a ideia do surgimento do gás através de suas experiências, preparou, isolou e estudou o oxigênio. Porém foi vítima da negligência de seu editor, e seu artigo só foi publicado em 1777. 
As ideias de Priestley culminaram que o ar não é uma substância elementar, mas sim uma composição ou mistura de gases. Entre eles estava o gás incolor e altamente reativo, o qual a partir de suas experiências chamou de "gás" desflogisticado.

Para Lavoisier, explicar as reações químicas tornou-se desafiador. Seus estudos foram de extrema importância para mostrar como ocorre as reações de combustão. Realizou experiências de calcinação com metais, e concluiu que o ar que se combina com os mesmos é mais pesado que o ar da atmosfera, e então o chamou de oxigênio.

4-

Discussão do texto e do experimento: Parte Conceitual atrelado ao contexto histórico

Ao longo do desenvolvimento da ciência experimental moderna surgiu uma nova forma de buscar conhecimento, esta mudança teve várias contribuições de médicos, filósofos e alquimistas. Durante vários estudos foi possível a formulação de novas teorias, uma das mais marcantes para a história da química foi à teoria do flogístico, proposta pelo químico alemão Georg Ernst Stahl (1660-1774). Em 1731, ele propôs uma teoria explicativa para a combustão: segundo ele, os corpos combustíveis teriam como constituinte um "elemento", denominado flogístico, o qual era liberado durante a queima.

Sthal afirmou que todo material perde algo no processo de queima. E batizou esse material perdido como flogístico, também denominado na época "espirito ígneo". De acordo com essa teoria, quando um metal era queimado, liberava o flogístico, restando o que eles chamavam de "cal" do metal. O flogístico era considerado um dos elementos constitutivos da matéria, que seria liberado toda vez que o material sofresse combustão ou calcinação (aquecimento em alta temperatura). Para transformar a "cal” em metal, bastava devolver o flogístico por intermédio do carvão.

Calcinação

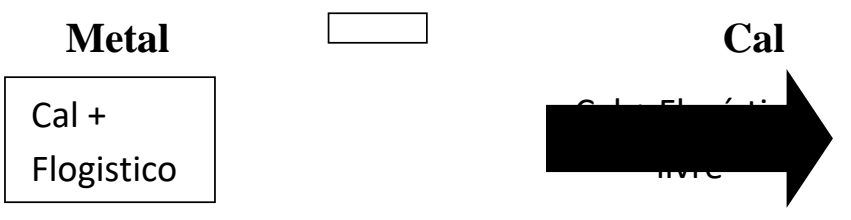




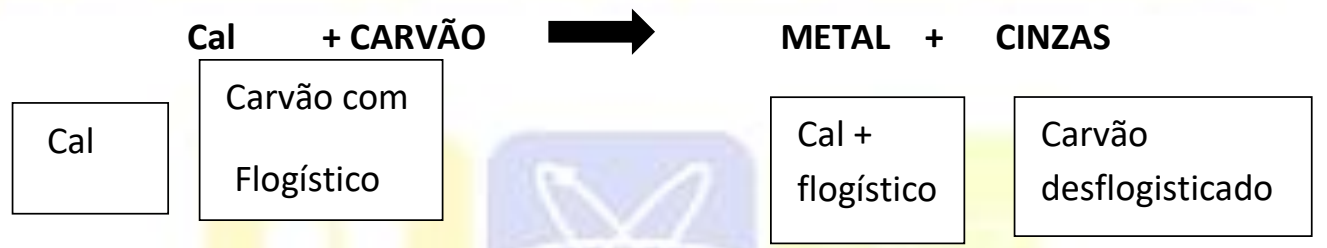

Embora as explicações baseadas na teoria do flogístico fossem razoáveis, ela apresentava incoerências em relação à variação de massa. Os alquimistas propagadores dessa teoria não realizaram experimentos quantitativos sobre combustão, mas mesmo assim foi aceita por durante algum tempo.

Todas as descobertas e especulações científicas daquela época eram transcritas através de periódicos especializados, daí a luta entre autores, assessores e editores era constante, com frequentes episódios tragicômicos. Uma das vítimas da negligência de seu editor foi o farmacêutico Carl Wilhelm Scheele (1742-1786) que não levou crédito por nenhuma de suas descobertas, inclusive a do oxigênio, tendo em vista que o mesmo preparou, isolou e estudou o oxigênio.

Em 1772, Scheele descobriu que o óxido de manganês em brasa produz um gás. Ele chamou o gás "ar de fogo" por causa das faíscas brilhantes que produziu quando ele entrou em contato com pó de carvão quente. Repetiu esta experiência com nitrato de potássio em aquecimento, óxido de mercúrio, e muitos outros materiais e produziu o mesmo gás. Daí, recolheu o gás na forma pura usando uma bolsa pequena. Ele explicou as propriedades do "ar de fogo", usando a teoria do flogisto.

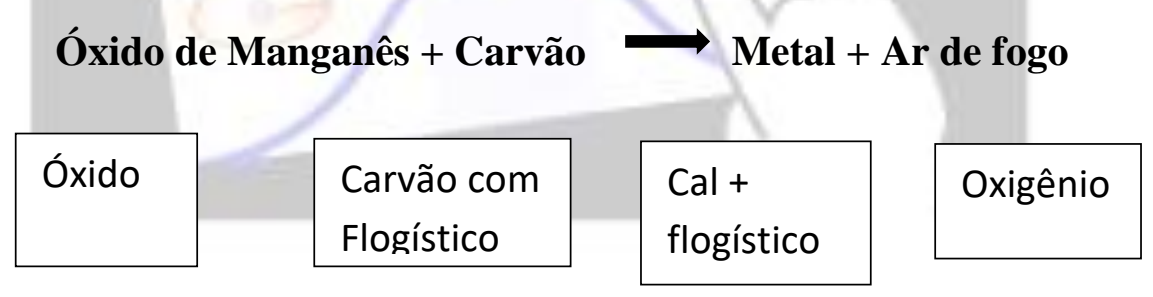


Joseph Priestley (1733-1804) começou suas investigações experimentais na química no ano de 1767. Enquanto bibliotecário, Priestley procurou direcionar seus estudos na calcinação do mercúrio obtido a partir de seu aquecimento no ar. Durante este experimento, observeou que uma parte do ar se desprendia, e em contato com a chama da vela notou que a mesma queimava melhor descrevendo sua chama como brilhante na presença deste ar. Priestley que não tinha conhecimento das condutas de segurança, resolveu inalar um pouco desse ar e o descrevou desta forma: "Sinto meu peito leve e confortável durante algum tempo depois. Quem sabe, no futuro, esse ar puro se torne um artigo de luxo em voga? Até então, dois camundongos e eu tivéramos o privilégio deste ar."

Em sua série de experimentos, no qual foi realizado o experimento da vela em um recipiente fechado, Priestley concluiu que havia encontrado um ar totalmente desprovido de flogístico o que fazia com que a vela queimasse por mais tempo, ele chamou de "ar deflogisticado", tornando o ar uma substância não elementar, mas uma composição", ou mistura, de gases.

Lavoisier também esteve envolvido com a descoberta do oxigênio, aprofundando os estudos de Priestley, mas suas análises e conclusões deram fim a teoria do flogístico. A partir de experiências bem controladas, medindo a variação de massa quando da combustão de várias substâncias simples com quantidade exatamente determinadas do oxigênio recém descoberto, Lavoisier demonstrou que a queima é uma reação com o oxigênio.

Aquilo que os alquimistas chamavam de cal do metal na verdade é um novo composto, o óxido metálico. A regeneração da cal ao metal pode ser feita aquecendo-a com o carvão porque, sendo este constituído pelo elemento químico carbono, formará gás carbônico (Dióxido de Carbono) por combinação com o oxigênio do óxido, deixando o metal livre.

Portanto, a queima do metal e a redução de seu óxido novamente ao metal não são processos de troca de flogístico, mas reações do metal com o oxigênio do ar (queima) ou do carvão com o óxido metálico (redução ao metal). [1]

Com base nas explicações acima surgiram os impactos sobre as reais concepções do oxigênio, pois naquela época se imaginava que este seria formado pelo "espirito do elemento" mais flogístico. Desta forma, foi possível comprovar que a teoria do flogístico não era consistente para explicar fatos como combustão, reações químicas e isolamento de um elemento puro. Quando se refere às reações químicas, diz: 
"Podemos estabelecer, como um axioma incontestável, que em todas as operações da arte e da natureza nada é criado: existe uma quantidade igual de matéria antes e depois do experimento; a qualidade e a quantidade dos elementos permanecem precisamente a mesma e nada acontece além de mudanças e modificações nas combinações desses elementos".

\section{Lei da Conservação das Massas}

A partir do experimento da palha de aço podemos obter resultados equivocados sobre a variação de massa nas reações de combustão. Se aquelas reações fossem manuseadas em recipientes fechados, constataríamos que não há variação de massa durante a combustão. Essa observação pode ser obtida em vários tipos de reações químicas. O enunciado que se aplica a todas as reações químicas ficou conhecido até hoje como Lei da Conservação das Massas ou Lei de Lavoisier, no qual pode ser resumida na seguinte frase: Na natureza nada se cria, nada se perde, tudo se transforma.

Algumas concepções em relação à combustão são errôneas, como por exemplo, o desaparecimento da matéria nas reações de combustão. O que acontece de fato é que como em toda reação química, na combustão a massa dos produtos é igual a massa dos reagentes.

Quando Lavoisier publicou sua lei, muitos químicos e alquimistas duvidaram de sua validade, eles observaram que na queima de algumas substâncias havia uma variação na massa, enquanto umas aumentavam, outras diminuíam. Porém, Lavoisier ganhou mérito por ter descoberto que essas diferenças de massa ocorriam devido a absorção ou liberação de gases durante as reações.

Podemos observar que na combustão do papel, sua massa diminui porque nesse processo são formados gases que são liberados para a atmosfera. Em contrapartida na queima da palha de aço, há o consumo do oxigênio do ar, produzindo uma substância composta de ferro e oxigênio. Sendo assim, a massa da substância formada é maior que a massa da palha de aço. É possível esquematizar essa lei através da reação abaixo:

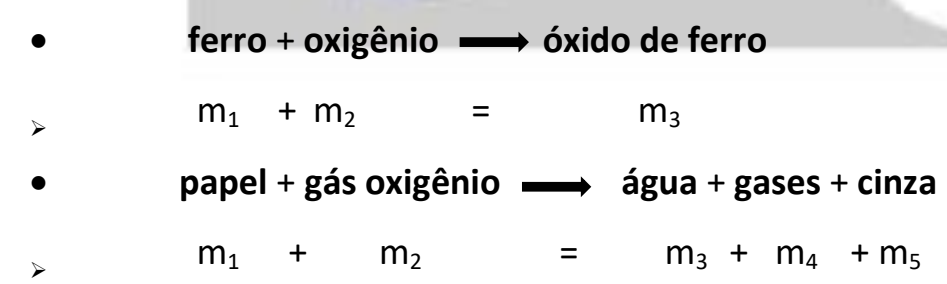


Segundo os dados acima, nas reações, a soma dos reagentes é igual à soma dos produtos. Matematicamente a Lei de Lavoisier pode ser descrita acima, sendo possível definir algumas regras de suma importância para a prática de cálculos em análises quantitativas.

\section{PARTE 2}

\section{1 - Atividade Experimental: Experiências com Vela}

Objetivo: Problematizar o processo de combustão da vela e sua relação com o consumo de oxigênio
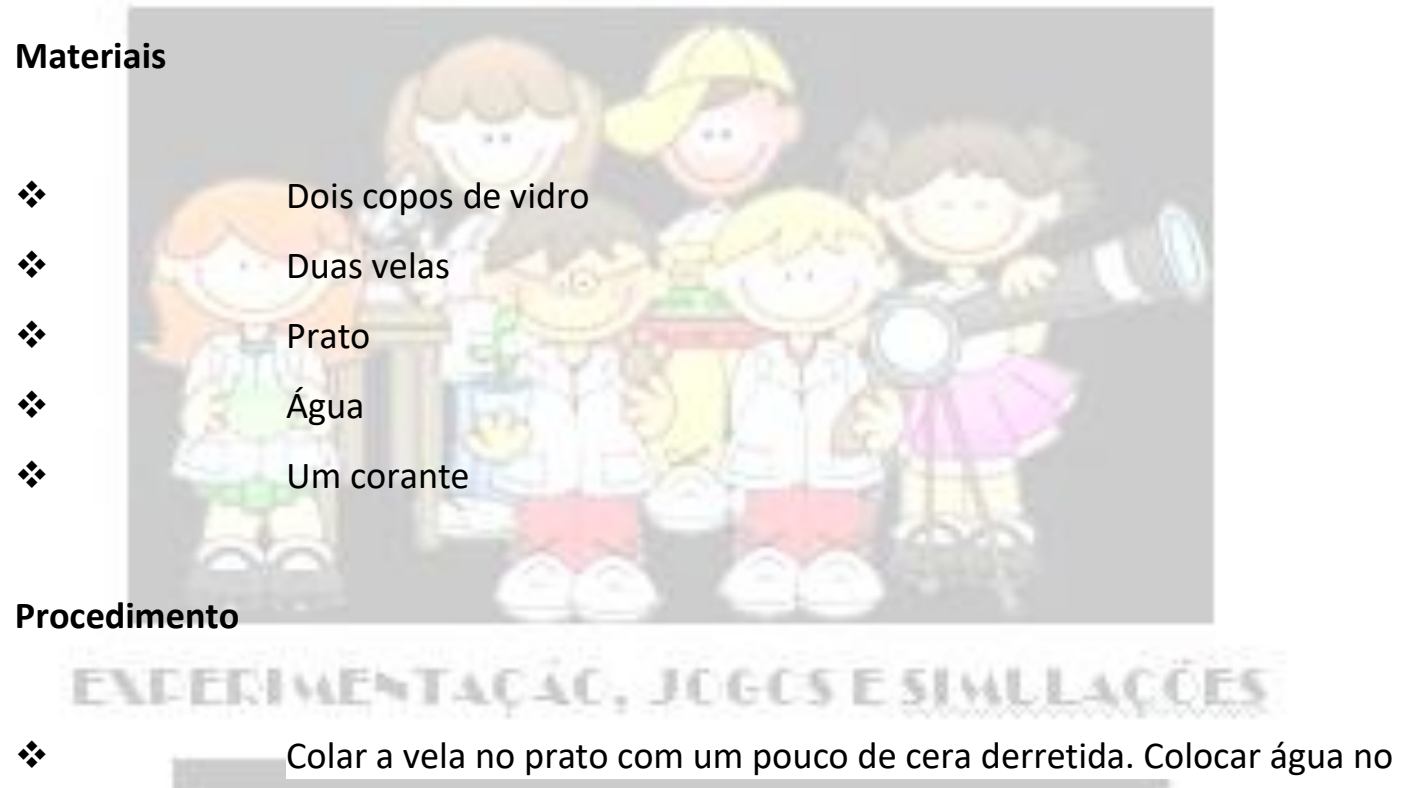
prato, acender a vela e cobrir com o copo de vidro como mostra a figura. Em seguida utilizar duas velas, uma menor e outra maior e realizar o mesmo procedimento. Observar o ocorrido.

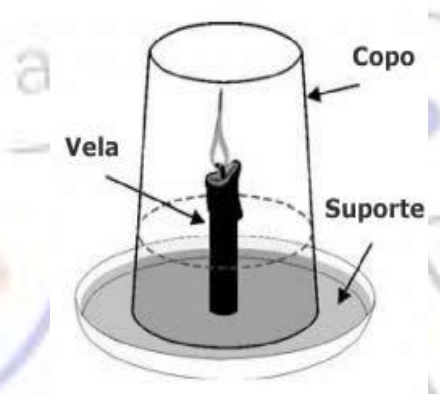

Figura 2. Esquema do experimento. 


\section{Perguntas investigativas}
$1-$
O que faz com que a água entre no copo?
$2-$
Como você explicaria a vela maior cessar primeiro?
$3-$
$O$ oxigênio é totalmente consumido quando a vela se apaga?
$4-$
De que é feito a chama da vela? O que faz a vela ficar acessa?

\section{3 - Explicação}

De fato, a explicação para a elevação da água é provida da lei de Charles (comportamento dos gases). Segundo Charles, o ar como qualquer gás, se expande quando aquecido e contrai quando resfriado. A vela aquece o ar à sua volta, de modo a esquentar o ar contido no frasco, sendo que este é mais quente no início do experimento do que no final. Como o ar contido no frasco esfria, ele se contrai, e grande parte do seu resfriamento ocorre enquanto a vela ainda queima. Os saberes da físico-química relatam que as temperaturas mais baixas, significam menores pressões. Portanto, pode-se dizer que o ar no frasco exerce menor pressão sobre a água quando a temperatura diminui, de modo que o nível da água sobe.

A perda de oxigênio é parcialmente compensada pelo ganho de $\mathrm{CO}_{2} \mathrm{e}$ vapor de água, mas o volume de água que subiu não é o suficiente para substituir o ar perdido, pois seu volume não é igual à quantidade de oxigênio que foi consumido. Mesmo se todo $\mathrm{O}_{2}$ fosse consumido (cerca de $21 \%$ ), não seria possível uma redução de $21 \%$ na quantidade total do gás no recipiente. Assim, o volume de água que subiu não é igual a quantidade de oxigênio consumido pela chama.

Os produtos da combustão são bastante quentes, tornando-os menos denso que o ar atmosférico que em parte é composto por oxigênio. Assim, eles "flutuam" para cima (parte superior do frasco), forçando os outros gases para baixo. Desta forma, o $\mathrm{CO}_{2}$ acumulado atinge primeiro a vela maior, já que a mesma se encontra mais próxima da parte superior do frasco. Já com a vela mais curta o comportamento é oposto, o vapor da água é condensado e o $\mathrm{CO}_{2}$ se dissolve parcialmente em água, reduzindo a quantidade de gás no frasco. Desta forma, a parte superior do frasco fica um pouco desprovida de gás, fazendo com que a vela demore mais para apagar. 
Nas reações de combustão são necessários o contato entre o combustível e o comburente formando uma fonte de calor e geralmente também é necessário uma energia de ignição para iniciar a reação como, por exemplo, o fósforo. Na reação de combustão da vela, o combustível é a parafina, é o que está sendo queimado, já o oxigênio é o comburente, pois é necessário está presente para que ocorra a queima. $\mathrm{O}$ pavio exerce a função de ser queimado para produzir fogo, portanto é a fonte de calor.

\section{PARTE 3}

1Reações Químicas: Consumo de Oxigênio.

Objetivo: problematizar o consumo de oxigênio em uma reação de oxi-redução.

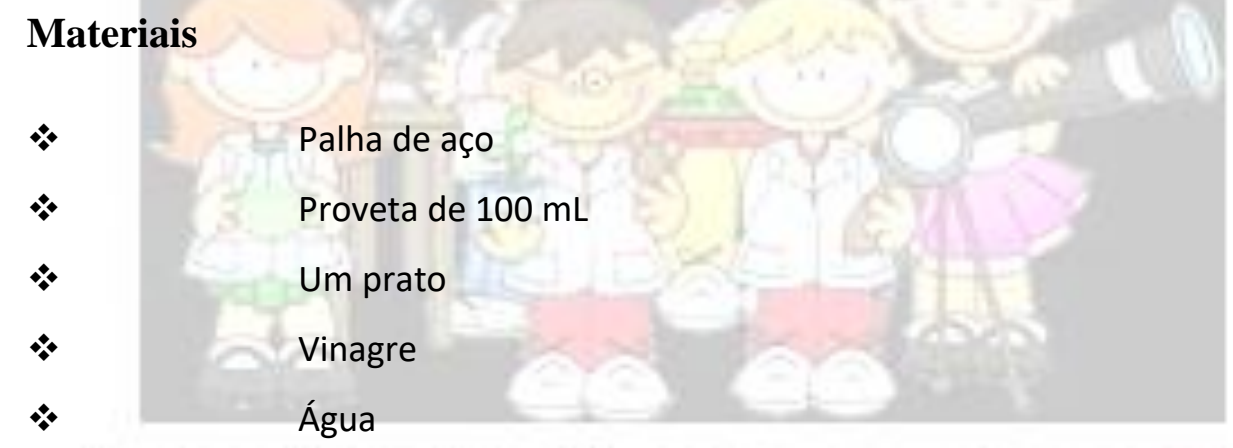

\section{Procedimento}

Molhar um pedaço de palha de aço em vinagre por um minuto, depois dar uma sacudida para eliminar o excesso de vinagre. Colocar a palha de aço no fundo da proveta e emborcar no prato com água. Aguardar por aproximadamente 20 minutos.

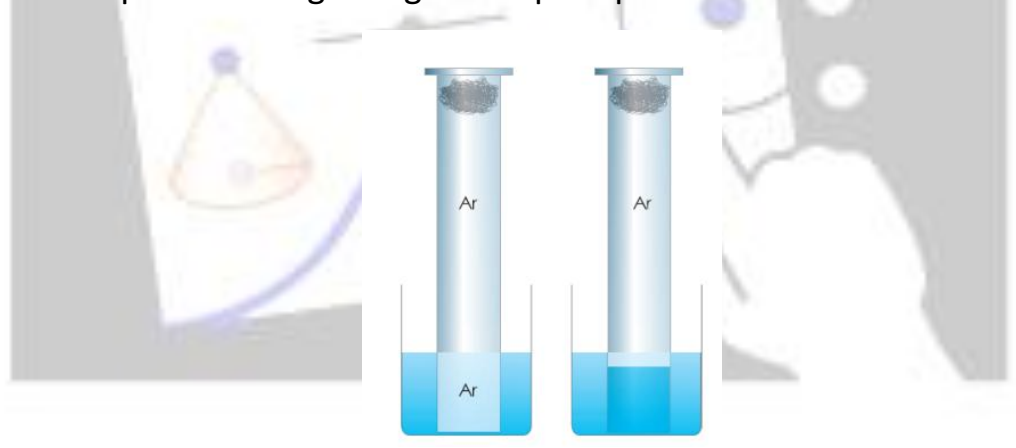

Figura 3: Esquema do experimento da palha de aço 


\section{Perguntas investigativas}

$1-$ Com o que você relacionaria o aumento da água no recipiente?

2$\mathrm{O}$ que aconteceu com a palha de aço? Explique.

3Qual o papel do vinagre no decorrer da reação?

2-

\section{Discussão do experimento.}

A porcentagem de oxigênio no ar foi determinada pela primeira vez com exatidão por Lavoisier, que aqueceu, em recipiente fechado, uma quantidade conhecida de ar, em contato com mercúrio. Passados doze dias, o mercúrio absorverá um quinto do ar existente e apresentava-se coberto de placas vermelhas. Mediante novo aquecimento, Lavoisier fez o mercúrio liberar uma quantidade equivalente de oxigênio. No nosso diaa-dia podemos perceber esse fenômeno ocorrendo com muita facilidade. A ferrugem é um exemplo bastante clássico e é um caso particular de oxidação, quando temos a deposição de oxigênio na superfície de objetos à base de ferro. Esse processo provoca a corrosão desses metais.

Primeiramente, foi possível observar que ao retirar o excesso de vinagre da palha de aço e coloca-la na proveta, a mesma obteve uma coloração amarela sobre sua superfície. Vale lembrar, que a palha de aço é uma liga metálica formada essencialmente por ferro e carbono, sendo que o ferro apresenta-se em maior quantidade. $\mathrm{O}$ ferro, em contato com o ar ou água, sofre oxidação, enquanto que o oxigênio sofre redução (agente oxidante). Segue a reação abaixo:

$$
\mathrm{Fe}(\mathrm{s})+\mathrm{O}_{2}(\mathrm{~g}) \rightarrow \mathrm{FeO}_{2}(\mathrm{~s})
$$

Analisou-se que o vinagre (ácido acético) tem a finalidade de limpar a superfície da palha, eliminando os óxidos presente na mesma. Entretanto, apenas "limpar" a superfície da palha de aço, não é o suficiente. Sabe-se que a remoção completa do ácido acético é prejudicial à velocidade do experimento, o que sugere que o vinagre desempenhe um possível papel catalisador (acelera a reação). Sem o auxílio do vinagre, o experimento levaria dias para ser concluído, pois os outros ácidos liberam íons $\mathrm{H}^{+}$(aq). Os íons acetatos desempenham um papel na aceleração no processo de oxidação da palha de aço. 
Logo após observar o experimento durante 40 minutos, o nível da água permanece inalterado. Isto evidencia que a reação de oxidação do ferro é limitada por falta de oxigênio. A reação vai ocorrendo e o oxigênio dentro do tubo vai sendo consumido. Isso gera uma diferença de pressão entre a parte interna e externa. A pressão dentro do recipiente fica menor e com isso a pressão atmosférica "empurra" a água para dentro do cilindro. Assim, foi possível observar a mudança no nível de água no interior do recipiente.

\section{REFERÊNCIAS BIBLIOGRÁFICAS}

\section{Academia}

Britânica,

disponível

em:

< http://www.britannica.com/EBchecked/topic/475975/Joseph-Priestley/218488/The-

chemistry-of-gases?anchor=ref100769>. Acesso em 15/06/2015.

FARIAS, R. F. Para gostar de ler a história da química. Campinas, SP: Ed: Átomo, 2004.

Historia y Filosofía de la Ciencia. Biografia. Disponível em: <http://pioneros.puj.edu.co/biografias/edad moderna/1640 1710/george ernest stahl.html $\geq$.

LAVOISIER. Uma revolução na Química: uma proposta de ensino a partir da história e filosofia da ciência. 2011. Disponível em < http://www.pibid.ufpr.br/pibid new/uploads/quimica2009/arquivo/308/PD HFC Caroline e Luciana.pdf>. Acesso em 15/06/2015.

VANIN, J. A. Alquimistas e Químicos: o passado, o presente e o futuro. São Paulo: Moderna, 2005.

VIDAL, P. H. O.; CHELONI, F. Ol.; PORTO, P. A. O Lavoisier que não está presente nos livros didáticos. QNEsc, n.6, 2007. 


\section{UFS - Mestrado em Ensino de Ciências e matemática}

Disciplina: O Ensino Experimental em Ciências Naturais

Autores: Maria Elane Mendonça Santos \& Nirly Araujo dos Reis

Docente: Luiz Adolfo de Mello

\section{Sequência Didática: a Existência do Oxigênio.}

\section{Apresentação e Justificativa}

O oxigênio é uma substância essencial para os seres vivos. Está presente no planeta terra desde o menor organismo vivo até no ar, nos oceanos. Constitui $65 \%$ do corpo humano e participa de muitas reações químicas, destacando as reações de combustão. Porém, até que a sociedade soubesse o quão importante era este elemento, ocorreram controvérsias a respeito da existência deste gás. Nessa perspectiva, esta sequência irá discutir experimentos que problematizam o surgimento do oxigênio, considerando o contexto histórico atrelado as reações de combustão a ele relacionada.

\section{Objetivo}

Discutir o princípio das reações de combustão e conservação da matéria a partir de um enfoque histórico. 


\section{Desenvolvimento da Sequência}

\section{PARTE 1}

\section{1 - Atividade Experimental: A controvérsia Histórica.}

Objetivo: Discutir algumas evidências experimentais que levaram a controvérsias históricas em torno da existência do oxigênio.

\section{- Experimento da balança}

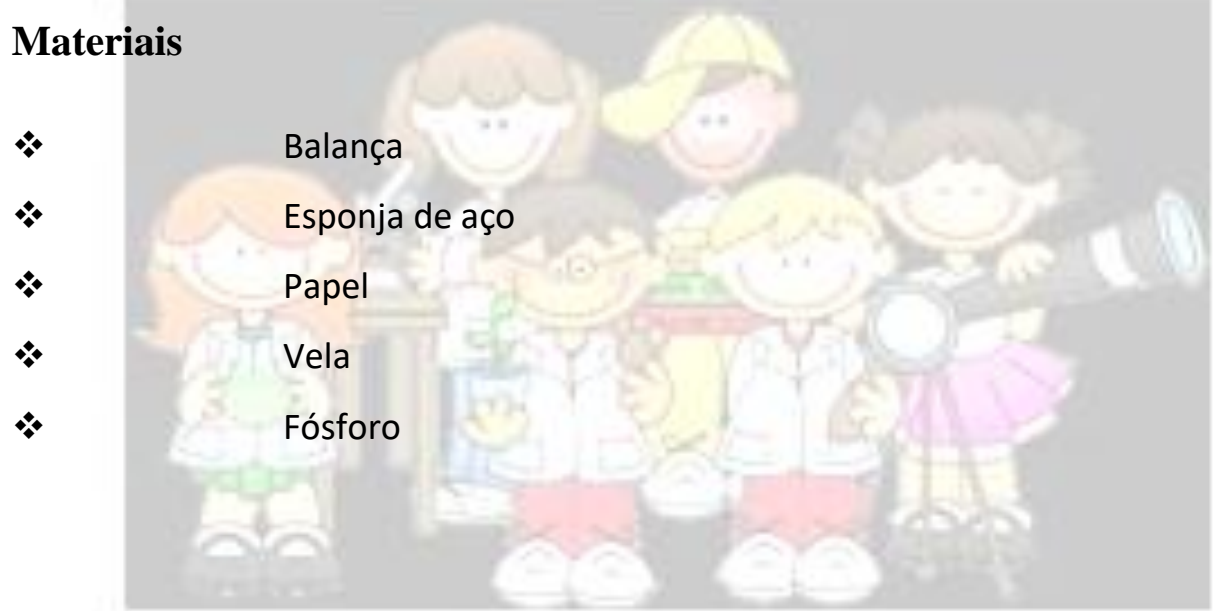

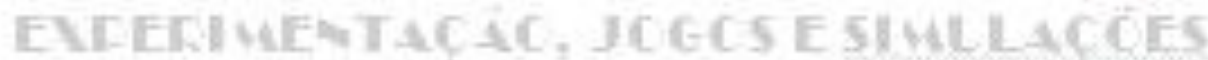

\section{Procedimento}

\section{Parte A}

$5-$

Construa uma balança, como a da figura.

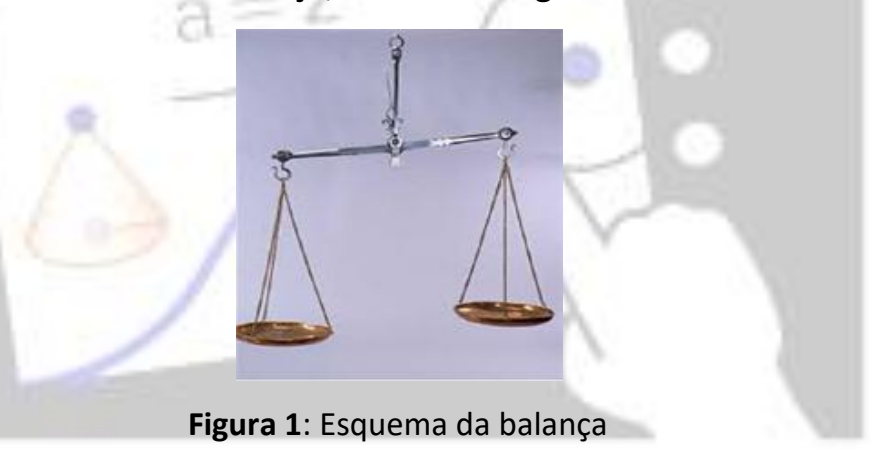

$6-$

Coloque em cada prato uma folha de papel e estabilize a balança.

7Ponha fogo em um dos papeis. 
sua massa.

\section{Parte B}

5- $\quad$ Coloque em cada prato um pedaço de palha de aço e estabilize a balança.

6- $\quad$ Ponha fogo na palha de aço.

7- $\quad$ Observe a combustão e anote o que aconteceu com a palha de aço e com sua massa.

\section{Perguntas investigativas}

6-

O que aconteceu com a massa do papel após a combustão? Como você

explica este acontecimento?

7-

O que aconteceu com a massa da palha de aço após a combustão?

Como você explica este acontecimento?

$8-$

$\mathrm{O}$ que diferencia o experimento $\mathrm{A}$ com o experimento B? Explique.

9-

O que deve ter contribuído para a variação das massas do papel e da

palha de aço?

$10-$

Imaginando que as duas reações sejam realizadas em recipientes fechados, explique o que aconteceria com as massas dos sistemas.

\section{3-}

\section{Perguntas Problematizadoras}

$5-$

Na época que a lei de Lavoisier foi registrada, muitos químicos chegaram a duvidar de sua validade, pois havia observado que na queima de algumas substâncias, havia aumento de massa, enquanto que em outras havia diminuição. Como você explicaria este fenômeno.

6-

O corpo humano é constituído por, pelo menos, cerca de 60 produtos químicos diferentes, muitos dos quais são desconhecidos no próprio organismo. Todos nós sabemos a importância da água para a vida e $60 \%$ do peso corporal é água. 0 oxigênio ocupa o primeiro lugar na lista e faz-se $65 \%$ do corpo. Como poderíamos explicar a diferença entre a massa de um corpo vivo e um corpo morto?

7- $\quad$ No século XVIII Lavoisier e outros químicos compreendiam que durante a respiração um fluído elástico passava pelos corpos. Considerando as trocas gasosas que 
ocorrem durante a respiração, quais substâncias estariam relacionadas a este fluído? A respiração pode ser considerada uma reação de combustão?

$8-$

Os cientistas do século XVIII desconheciam a composição do ar atmosférico, mas por meio da realização de experimentos sobre combustão, observaram que o ar sofria alterações. Para diferenciar esses tipos de ares, foi criada uma classificação: ar puro, para ar atmosférico, ar vital, para o ar absorvido na combustão e ar fixo para o ar que não participava da reação. Você conhece os gases que compõem o ar atmosférico? Quais gases estão relacionados ao ar vital e ao ar fixo?

Q - Como eles chegaram a conclusão de que o fluido possui propriedades de elasticidade?

3 - Texto: $O$ contexto histórico e as hipóteses da existência de um novo gás.

Apresentar de forma breve, algumas das discussões históricas em torno do experimento anterior.

O pensamento ocidental da antiguidade traz consigo discussões filosóficas sobre o desenvolvimento científico, que conquistou espaço ao longo dos anos. A ciência não é feita da noite pro dia, vários pensamentos surgem até que seja montada uma estrutura teórica, baseado em experiências ou não, no caso deste último a linguagem matemática. Durante o século XVIII vários personagens fizeram parte desta época tão marcante para a sociedade. Célebres acadêmicos como Georg Ernst Stahl (1660-1734), Carl Wilhelm Scheele (1742-1786), Joseph Priestley (1733-1804) e Antoine Laurent Lavoisier (1743-1794).

A descoberta do oxigênio foi um dos maiores triunfos da ciência, e todos os cientistas citados acima tiveram sua contribuição para desvendar todos os mistérios desse gás. De início ele foi chamado de flogisto, assim nomeado pelo Ernst Stahl, onde afirmava que toda substância que ardia continha um princípio combustível, que ao ser queimado liberava o gás flogisto. Scheele reforçou a ideia do surgimento do gás através de suas experiências, preparou, isolou e estudou o oxigênio. Porém foi vítima da negligência de seu editor, e seu artigo só foi publicado em 1777. 
As ideias de Priestley culminaram que o ar não é uma substância elementar, mas sim uma composição ou mistura de gases. Entre eles estava o gás incolor e altamente reativo, o qual a partir de suas experiências chamou de "gás" desflogisticado.

Para Lavoisier, explicar as reações químicas tornou-se desafiador. Seus estudos foram de extrema importância para mostrar como ocorre as reações de combustão. Realizou experiências de calcinação com metais, e concluiu que o ar que se combina com os mesmos é mais pesado que o ar da atmosfera, e então o chamou de oxigênio.

8-

Discussão do texto e do experimento: Parte Conceitual atrelado ao contexto histórico

Ao longo do desenvolvimento da ciência experimental moderna surgiu uma nova forma de buscar conhecimento, esta mudança teve várias contribuições de médicos, filósofos e alquimistas. Durante vários estudos foi possível a formulação de novas teorias, uma das mais marcantes para a história da química foi à teoria do flogístico, proposta pelo químico alemão Georg Ernst Stahl (1660-1774). Em 1731, ele propôs uma teoria explicativa para a combustão: segundo ele, os corpos combustíveis teriam como constituinte um "elemento", denominado flogístico, o qual era liberado durante a queima.

Sthal afirmou que todo material perde algo no processo de queima. E batizou esse material perdido como flogístico, também denominado na época "espirito ígneo". De acordo com essa teoria, quando um metal era queimado, liberava o flogístico, restando o que eles chamavam de "cal" do metal. O flogístico era considerado um dos elementos constitutivos da matéria, que seria liberado toda vez que o material sofresse combustão ou calcinação (aquecimento em alta temperatura). Para transformar a "cal” em metal, bastava devolver o flogístico por intermédio do carvão.

Calcinação

\begin{tabular}{|l|}
\multicolumn{1}{|c|}{ Metal } \\
\hline Cal + \\
Flogistico \\
\hline
\end{tabular}

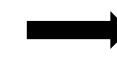

Cal

Cal + Flogístico livre 


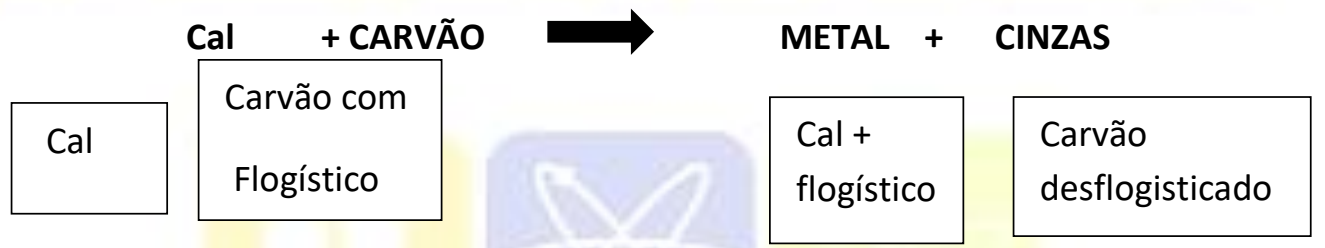

Embora as explicações baseadas na teoria do flogístico fossem razoáveis, ela apresentava incoerências em relação à variação de massa. Os alquimistas propagadores dessa teoria não realizaram experimentos quantitativos sobre combustão, mas mesmo assim foi aceita por durante algum tempo.

Todas as descobertas e especulações científicas daquela época eram transcritas através de periódicos especializados, daí a luta entre autores, assessores e editores era constante, com frequentes episódios tragicômicos. Uma das vítimas da negligência de seu editor foi o farmacêutico Carl Wilhelm Scheele (1742-1786) que não levou crédito por nenhuma de suas descobertas, inclusive a do oxigênio, tendo em vista que o mesmo preparou, isolou e estudou o oxigênio.

Em 1772, Scheele descobriu que o óxido de manganês em brasa produz um gás. Ele chamou o gás "ar de fogo" por causa das faíscas brilhantes que produziu quando ele entrou em contato com pó de carvão quente. Repetiu esta experiência com nitrato de potássio em aquecimento, óxido de mercúrio, e muitos outros materiais e produziu o mesmo gás. Daí, recolheu o gás na forma pura usando uma bolsa pequena. Ele explicou as propriedades do "ar de fogo", usando a teoria do flogisto.

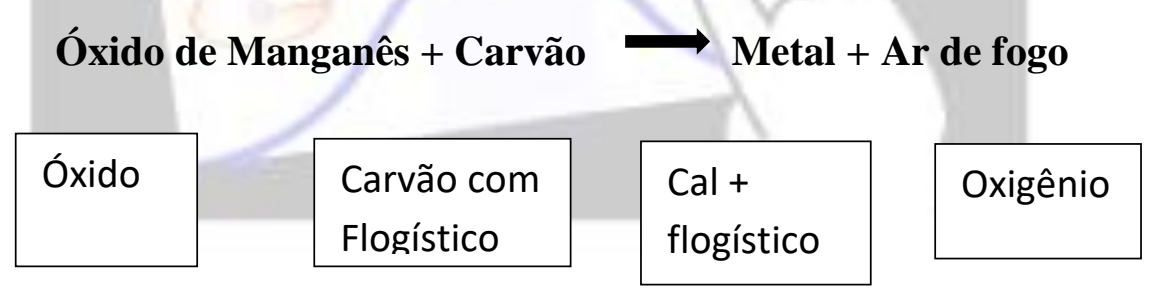


Joseph Priestley (1733-1804) começou suas investigações experimentais na química no ano de 1767. Enquanto bibliotecário, Priestley procurou direcionar seus estudos na calcinação do mercúrio obtido a partir de seu aquecimento no ar. Durante este experimento, observeou que uma parte do ar se desprendia, e em contato com a chama da vela notou que a mesma queimava melhor descrevendo sua chama como brilhante na presença deste ar. Priestley que não tinha conhecimento das condutas de segurança, resolveu inalar um pouco desse ar e o descrevou desta forma: "Sinto meu peito leve e confortável durante algum tempo depois. Quem sabe, no futuro, esse ar puro se torne um artigo de luxo em voga? Até então, dois camundongos e eu tivéramos o privilégio deste ar."

Em sua série de experimentos, no qual foi realizado o experimento da vela em um recipiente fechado, Priestley concluiu que havia encontrado um ar totalmente desprovido de flogístico o que fazia com que a vela queimasse por mais tempo, ele chamou de "ar deflogisticado", tornando o ar uma substância não elementar, mas uma composição", ou mistura, de gases.

Lavoisier também esteve envolvido com a descoberta do oxigênio, aprofundando os estudos de Priestley, mas suas análises e conclusões deram fim a teoria do flogístico. A partir de experiências bem controladas, medindo a variação de massa quando da combustão de várias substâncias simples com quantidade exatamente determinadas do oxigênio recém descoberto, Lavoisier demonstrou que a queima é uma reação com o oxigênio.

Aquilo que os alquimistas chamavam de cal do metal na verdade é um novo composto, o óxido metálico. A regeneração da cal ao metal pode ser feita aquecendo-a com o carvão porque, sendo este constituído pelo elemento químico carbono, formará gás carbônico (Dióxido de Carbono) por combinação com o oxigênio do óxido, deixando o metal livre.

Portanto, a queima do metal e a redução de seu óxido novamente ao metal não são processos de troca de flogístico, mas reações do metal com o oxigênio do ar (queima) ou do carvão com o óxido metálico (redução ao metal). [1]

Com base nas explicações acima surgiram os impactos sobre as reais concepções do oxigênio, pois naquela época se imaginava que este seria formado pelo "espirito do elemento" mais flogístico. Desta forma, foi possível comprovar que a teoria do flogístico não era consistente para explicar fatos como combustão, reações químicas e isolamento de um elemento puro. Quando se refere às reações químicas, diz: 
"Podemos estabelecer, como um axioma incontestável, que em todas as operações da arte e da natureza nada é criado: existe uma quantidade igual de matéria antes e depois do experimento; a qualidade e a quantidade dos elementos permanecem precisamente a mesma e nada acontece além de mudanças e modificações nas combinações desses elementos".

\section{Lei da Conservação das Massas}

A partir do experimento da palha de aço podemos obter resultados equivocados sobre a variação de massa nas reações de combustão. Se aquelas reações fossem manuseadas em recipientes fechados, constataríamos que não há variação de massa durante a combustão. Essa observação pode ser obtida em vários tipos de reações químicas. O enunciado que se aplica a todas as reações químicas ficou conhecido até hoje como Lei da Conservação das Massas ou Lei de Lavoisier, no qual pode ser resumida na seguinte frase: Na natureza nada se cria, nada se perde, tudo se transforma.

Algumas concepções em relação à combustão são errôneas, como por exemplo, o desaparecimento da matéria nas reações de combustão. O que acontece de fato é que como em toda reação química, na combustão a massa dos produtos é igual a massa dos reagentes.

Quando Lavoisier publicou sua lei, muitos químicos e alquimistas duvidaram de sua validade, eles observaram que na queima de algumas substâncias havia uma variação na massa, enquanto umas aumentavam, outras diminuíam. Porém, Lavoisier ganhou mérito por ter descoberto que essas diferenças de massa ocorriam devido a absorção ou liberação de gases durante as reações.

Podemos observar que na combustão do papel, sua massa diminui porque nesse processo são formados gases que são liberados para a atmosfera. Em contrapartida na queima da palha de aço, há o consumo do oxigênio do ar, produzindo uma substância composta de ferro e oxigênio. Sendo assim, a massa da substância formada é maior que a massa da palha de aço. É possível esquematizar essa lei através da reação abaixo:

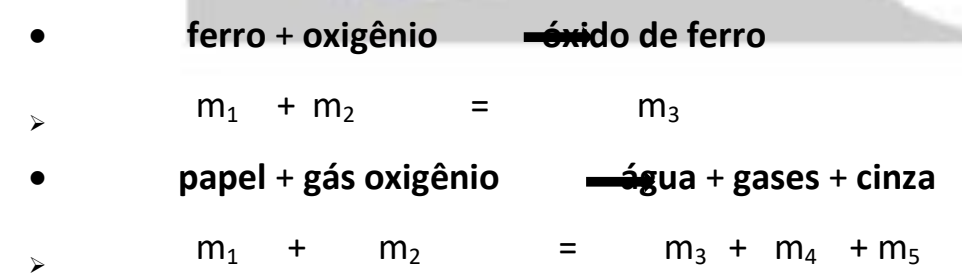


Segundo os dados acima, nas reações, a soma dos reagentes é igual à soma dos produtos. Matematicamente a Lei de Lavoisier pode ser descrita acima, sendo possível definir algumas regras de suma importância para a prática de cálculos em análises quantitativas.

\section{PARTE 2}

\section{1 - Atividade Experimental: Experiências com Vela}

Objetivo: Problematizar o processo de combustão da vela e sua relação com o consumo de oxigênio
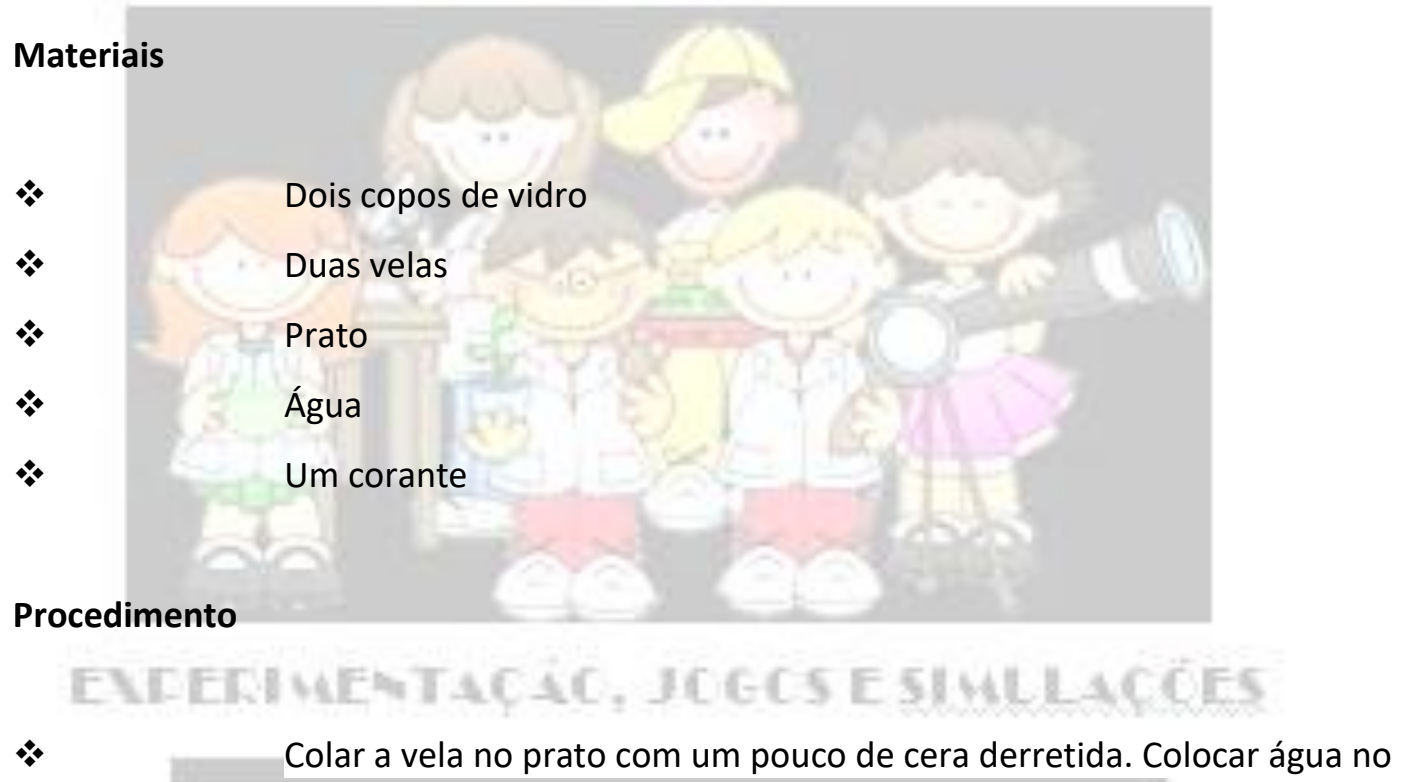
prato, acender a vela e cobrir com o copo de vidro como mostra a figura. Em seguida utilizar duas velas, uma menor e outra maior e realizar o mesmo procedimento. Observar o ocorrido.

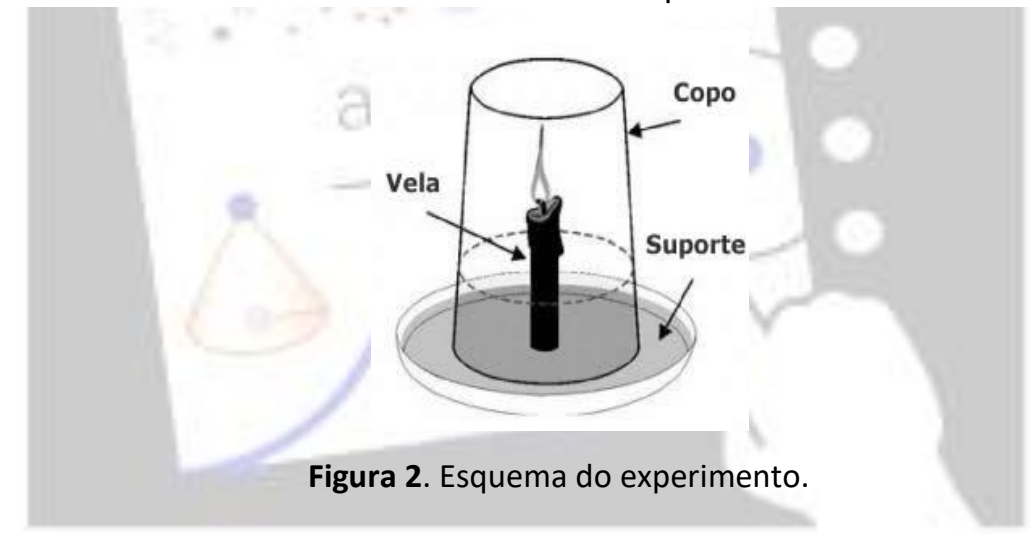


$5-$

6-

7-

$8-$
O que faz com que a água entre no copo?

Como você explicaria a vela maior cessar primeiro?

O oxigênio é totalmente consumido quando a vela se apaga?

De que é feito a chama da vela? O que faz a vela ficar acessa?

4

\section{- Explicação}

De fato, a explicação para a elevação da água é provida da lei de Charles (comportamento dos gases). Segundo Charles, o ar como qualquer gás, se expande quando aquecido e contrai quando resfriado. A vela aquece o ar à sua volta, de modo a esquentar o ar contido no frasco, sendo que este é mais quente no início do experimento do que no final. Como o ar contido no frasco esfria, ele se contrai, e grande parte do seu resfriamento ocorre enquanto a vela ainda queima. Os saberes da físico-química relatam que as temperaturas mais baixas, significam menores pressões. Portanto, pode-se dizer que o ar no frasco exerce menor pressão sobre a água quando a temperatura diminui, de modo que o nível da água sobe.

A perda de oxigênio é parcialmente compensada pelo ganho de $\mathrm{CO}_{2} \mathrm{e}$ vapor de água, mas o volume de água que subiu não é o suficiente para substituir o ar perdido, pois seu volume não é igual à quantidade de oxigênio que foi consumido. Mesmo se todo $\mathrm{O}_{2}$ fosse consumido (cerca de $21 \%$ ), não seria possível uma redução de $21 \%$ na quantidade total do gás no recipiente. Assim, o volume de água que subiu não é igual a quantidade de oxigênio consumido pela chama.

Os produtos da combustão são bastante quentes, tornando-os menos denso que o ar atmosférico que em parte é composto por oxigênio. Assim, eles "flutuam" para cima (parte superior do frasco), forçando os outros gases para baixo. Desta forma, o $\mathrm{CO}_{2}$ acumulado atinge primeiro a vela maior, já que a mesma se encontra mais próxima da parte superior do frasco. Já com a vela mais curta o comportamento é oposto, o vapor da água é condensado e o $\mathrm{CO}_{2}$ se dissolve parcialmente em água, reduzindo a quantidade de gás no frasco. Desta forma, a parte superior do frasco fica um pouco desprovida de gás, fazendo com que a vela demore mais para apagar.

Nas reações de combustão são necessários o contato entre o combustível e o comburente formando uma fonte de calor e geralmente também é necessário uma 
energia de ignição para iniciar a reação como, por exemplo, o fósforo. Na reação de combustão da vela, o combustível é a parafina, é o que está sendo queimado, já o oxigênio é o comburente, pois é necessário está presente para que ocorra a queima. $\mathrm{O}$ pavio exerce a função de ser queimado para produzir fogo, portanto é a fonte de calor.

\section{PARTE 3}

3-

Reações Químicas: Consumo de Oxigênio.

Objetivo: problematizar o consumo de oxigênio em uma reação de oxi-redução.

\section{Materiais}

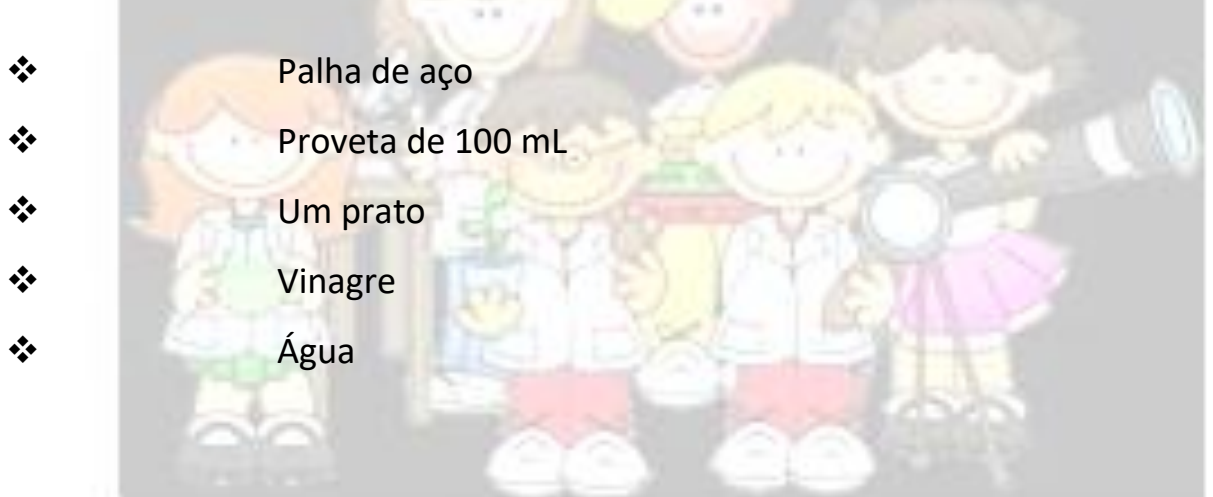

\section{Procedimento}

$*$

Molhar um pedaço de palha de aço em vinagre por um minuto, depois dar uma sacudida para eliminar o excesso de vinagre. Colocar a palha de aço no fundo da proveta e emborcar no prato com água. Aguardar por aproximadamente 20 minutos.
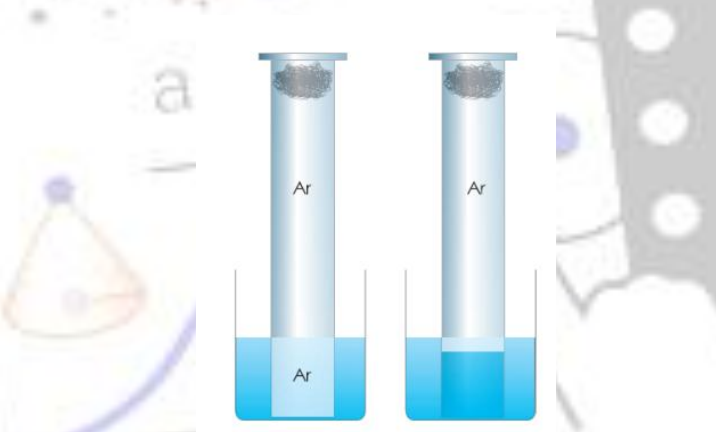

Figura 3: Esquema do experimento da palha de aço

\section{Perguntas investigativas}


4-

$5-$

6-

A porcentagem de oxigênio no ar foi determinada pela primeira vez com exatidão por Lavoisier, que aqueceu, em recipiente fechado, uma quantidade conhecida de ar, em contato com mercúrio. Passados doze dias, o mercúrio absorverá um quinto do ar existente e apresentava-se coberto de placas vermelhas. Mediante novo aquecimento, Lavoisier fez o mercúrio liberar uma quantidade equivalente de oxigênio. No nosso diaa-dia podemos perceber esse fenômeno ocorrendo com muita facilidade. A ferrugem é um exemplo bastante clássico e é um caso particular de oxidação, quando temos a deposição de oxigênio na superfície de objetos à base de ferro. Esse processo provoca a corrosão desses metais.

Primeiramente, foi possível observar que ao retirar o excesso de vinagre da palha de aço e coloca-la na proveta, a mesma obteve uma coloração amarela sobre sua superfície. Vale lembrar, que a palha de aço é uma liga metálica formada essencialmente por ferro e carbono, sendo que o ferro apresenta-se em maior quantidade. O ferro, em contato com o ar ou água, sofre oxidação, enquanto que o oxigênio sofre redução (agente oxidante). Segue a reação abaixo:

$$
\mathrm{Fe}(\mathrm{s})+\mathrm{O}_{2}(\mathrm{~g}) \rightarrow \mathrm{FeO}_{2}(\mathrm{~s})
$$

Analisou-se que o vinagre (ácido acético) tem a finalidade de limpar a superfície da palha, eliminando os óxidos presente na mesma. Entretanto, apenas "limpar" a superfície da palha de aço, não é o suficiente. Sabe-se que a remoção completa do ácido acético é prejudicial à velocidade do experimento, o que sugere que o vinagre desempenhe um possível papel catalisador (acelera a reação). Sem o auxílio do vinagre, o experimento levaria dias para ser concluído, pois os outros ácidos liberam íons $\mathrm{H}^{+}{ }_{\text {(aq) }}$. Os íons acetatos desempenham um papel na aceleração no processo de oxidação da palha de aço.

Logo após observar o experimento durante 40 minutos, o nível da água permanece inalterado. Isto evidencia que a reação de oxidação do ferro é limitada por falta de oxigênio. A reação vai ocorrendo e o oxigênio dentro do tubo vai sendo consumido. 
Isso gera uma diferença de pressão entre a parte interna e externa. A pressão dentro do recipiente fica menor e com isso a pressão atmosférica "empurra" a água para dentro do cilindro. Assim, foi possível observar a mudança no nível de água no interior do recipiente.

\section{REFERÊNCIAS BIBLIOGRÁFICAS}

Academia Britânica, disponível em: <http://www.britannica.com/EBchecked/topic/475975/Joseph-Priestley/218488/Thechemistry-of-gases?anchor=ref100769>. Acesso em 15/06/2015.

FARIAS, R. F. Para gostar de ler a história da química. Campinas, SP: Ed: Átomo, 2004.

Historia y Filosofía de la Ciencia. Biografia. Disponível em: $<$ http://pioneros.puj.edu.co/biografias/edad_moderna/1640_1710/george_ernest_stahl.ht $\underline{\mathrm{ml}>}$.

LAVOISIER. Uma revolução na Química: uma proposta de ensino a partir da história e filosofia da ciência. 2011. Disponível em < http://www.pibid.ufpr.br/pibid_new/uploads/quimica2009/arquivo/308/PD_HFC_Caroli ne_e_Luciana.pdf $>$. Acesso em 15/06/2015.

VANIN, J. A. Alquimistas e Químicos: o passado, o presente e o futuro. São Paulo: Moderna, 2005.

VIDAL, P. H. O.; CHELONI, F. Ol;; PORTO, P. A. O Lavoisier que não está presente nos livros didáticos. QNEsc, n.6, 2007. 


\title{
UFS - Mestrado em Ensino de Ciências e matemática
}

\author{
Disciplina: O Ensino Experimental em Ciências Naturais
}

Autores: Thisciane Ismerim Silva Santos e Leiliane

Docente: Luiz Adolfo de Mello

\section{Sequência Didática: Poluição Atmosférica}

\section{IDENTIFICANDO AS CONCEPÇÕES PRÉVIAS DOS ALUNOS}

Para melhor desenvolvimento do trabalho, inicialmente a turma será dividida em grupos contendo entre 4-6 participantes no máximo. Logo após, identificar-se-á as concepções prévias dos discentes (grupos formados) referentes a alguns conceitos que serão trabalhados em sala de aula durante a aplicação do projeto conforme está ilustrado na tabela 1, onde os discentes serão questionados a responderem o que eles entendem por esses termos.

Tabela 1 - Identificação das concepções prévias dos discentes

\begin{tabular}{|c|c|c|}
\hline TERMO & CONCEITO CIENTÍFICO & $\begin{array}{c}\text { CONCEPÇÕES } \\
\text { DOS ALUNOS }\end{array}$ \\
\hline Poluição atmosférica & $\begin{array}{l}\text { Refere-se a mudanças da atmosfera } \\
\text { susceptíveis de causar impacto a } \\
\text { nível ambiental ou de saúde } \\
\text { humana, através da contaminação } \\
\text { por gases, partículas sólidas, etc. }\end{array}$ & \\
\hline Chuva ácida & $\begin{array}{l}\text { Chuva com elevado teor de acidez } \\
\text { provocada pela forte concentração } \\
\text { de óxidos de enxofre e nitrogênio, } \\
\text { principalmente. }\end{array}$ & \\
\hline Óxidos & $\begin{array}{l}\text { São compostos formados por dois } \\
\text { elementos, no qual o Oxigênio é o } \\
\text { mais eletronegativa. }\end{array}$ & \\
\hline
\end{tabular}




\section{ESTRATÉGIAS DE ENSINO}

\subsection{Leitura interativa do texto didático feita pelo professor - Poluição}

Atmosférica

Com o interesse de despertar a curiosidade dos alunos a respeito da temática proposta, inicialmente haverá uma leitura interativa do texto (Poluição Atmosférica) abaixo por parte do professor.

\section{POLUIÇÃO ATMOSFÉRICA}

A poluição atmosférica é consequência, em maior parte, da ação humana, no sentido de introduzir produtos químicos e/ou tóxicos no ambiente. A queima de combustíveis fósseis -e não só ela - propicia a liberação de monóxido e dióxido de carbono, que corresponde a aproximadamente $45 \%$ dos poluentes liberados em grandes metrópoles. Inodoro e incolor, o CO tem capacidade de se ligar à hemoglobina sanguínea, podendo provocar asfixia.

Dióxido de nitrogênio, dióxido de enxofre lançados na atmosfera em grandes concentrações quando entra em contato com a humidade do ar pode produzir ácido nítrico e ácido sulfúrico, respectivamente. Além desses, hidrocarbonetos e outras substâncias contribuem para poluição atmosférica, levando a irritação de mucosas e vias respiratórias, alteração da água são exemplos de consequências geradas pela alta emissão de poluentes.

Apesar de várias iniciativas governamentais e não governamentais, impactos ambientais de diversas magnitudes vêm ocorrendo e podem se agravar em razão desse problema. $O$ velho paradigma de que não há desenvolvimento sem que haja agressões bruscas ao meio ambiente é o principal responsável por esta questão.

Há menos de cinco décadas, o discurso dos ambientalistas era tido como exagero ou ponto de vista radical e infundado. Entretanto, é fato que, por exemplo, os teores de gás carbônico na atmosférica aumentam anualmente em torno de $0,5 \%$, a temperatura média da superfície de nosso planeta aumentou cerca de 5 으 C desde a época da Revolução Industrial e camadas inteiras e gigantescas de gelo das regiões polares são derretidas em velocidade assustadora como consequência da poluição do ar.

Extraído e adaptado do link: http://www.brasilescola.com/biologia/poluicao-atmosferica.htm

\subsection{Análise dos parágrafos contidos no texto}

1 e 2ㅇ Parágrafos 
10 § - A poluição atmosférica é consequência, em maior parte, da ação humana, no sentido de introduzir produtos químicos e/ou tóxicos no ambiente. A queima de combustíveis fósseis -e não só ela - propicia a liberação de monóxido e dióxido de carbono, que corresponde a aproximadamente $45 \%$ dos poluentes liberados em grandes metrópoles. Inodoro e incolor, o CO tem capacidade de se ligar à hemoglobina sanguínea, podendo provocar asfixia.

2ㅇ § - Dióxido de nitrogênio, dióxido de enxofre lançados na atmosfera em grandes concentrações quando entra em contato com a humidade do ar pode produzir ácido nítrico e ácido sulfúrico, respectivamente. Além desses, hidrocarbonetos e outras substâncias contribuem para poluição atmosférica, levando a irritação de mucosas e vias respiratórias, alteração da água, inversão térmica, efeito de estufa são exemplos de consequências geradas pela alta emissão de poluentes.

\subsubsection{Construindo os conceitos envolvidos sobre óxidos}

Identificando os tipos de substâncias que aparecem com frequência no texto:

$$
\mathrm{CO}, \mathrm{CO}_{2}, \mathrm{NO}_{2}, \mathrm{SO}_{2}
$$

Os alunos deverão observar que todas as substâncias apresentadas possuem em comum o elemento química oxigênio. Assim, Apresentadas as substâncias que aparecem com frequência, será abordado o conceito de óxido, segundo descrito abaixo.

Conceito incompleto de óxidos $\rightarrow$ são compostos formados por dois elementos no qual um deles tem que ser o oxigênio (composto binário).

Toda substância binária pode ser considerada um óxido? Será abordado como exemplo a substância $\mathrm{OF}_{2}$ e $\circ \mathrm{O}_{2} \mathrm{~F}_{2}$. Logo, o $\mathrm{OF}_{2}$ e o $\mathrm{O}_{2} \mathrm{~F}_{2}$ não são óxidos. Compostos desse tipo são denominados como fluoretos de oxigênio.

Conceito completo de óxido $\rightarrow$ são compostos formados por dois elementos (composto binário), no qual o oxigênio deve ser o mais eletronegativo.

Nomeação de Óxidos

10 composto: $\mathrm{CO} \rightarrow$ Monóxido de carbono;

2ㅇ composto: $\mathrm{CO}_{2} \rightarrow$ Dióxido de carbono;

3 composto: $\mathrm{NO}_{2} \rightarrow$ Dióxido de nitrogênio;

4ํ composto: $\mathrm{SO}_{2} \rightarrow$ Dióxido de enxofre;

5o composto: $\mathrm{N}_{2} \mathrm{O}_{5} \rightarrow$ Pentóxido de dinitrogênio.

Observa-se que em todas as nomeações aparecem o nome óxido. Os prefixos, mono, di,..., são para indicar a quantidade de oxigênio presente e do elemento ligado a ele. Então, quando se tem um oxigênio, nomeia-se como monóxido; dois oxigênios, dióxido; três oxigênios, trióxido, 
e assim sucessivamente. Logo após, é só acrescentar a palavra "de" e o nome do elemento presente na fórmula, conforme ilustrado acima.

NOTA: o uso do prefixo mono é facultativo na nomeação.

Caso o elemento, metal, ligado ao oxigênio forme dois cátions diferentes, a distinção é feita com a indicação da carga que o elemento químico apresentar:

FeO: óxido de ferro II ou óxido ferroso

$\mathrm{Fe}_{2} \mathrm{O}_{3}$ : óxido de ferro III ou oxido férrico

A frase retirada do texto "A queima de combustíveis fósseis - e não só ela - propicia a liberação de monóxido e dióxido de carbono".

Esse tipo de poluição causada pela queima de combustíveis fósseis é denominada como poluição antropogênica. Define-se como poluição antropogênica: efeitos, processos, objetos derivados de atividades humanas, em oposição a aqueles que ocorrem em ambientes naturais sem influência humana.

Os óxidos citados acima podem ser classificados como poluentes primários, ou seja, são os poluentes diretamente introduzidos no meio ambiente. No entanto, quando esses poluentes são emitidos em grandes quantidades na atmosfera podem gerar outros produtos considerados como poluente secundário, por exemplo, o ácido sulfúrico e nítrico. Define-se poluente secundário as substâncias resultantes de transformações físicas e químicas na atmosfera, por parte de poluentes primários, por exemplo, o ácido sulfúrico e nítrico decorrente dos óxidos $\mathrm{NO}_{2}$ e $\mathrm{SO}_{3}$.

Conceituando Poluição Atmosférica:

$O$ trecho do texto $\rightarrow$ hidrocarbonetos e outras substâncias contribuem para poluição atmosférica, levando a irritação de mucosas e vias respiratórias, alteração da água são exemplos de consequências geradas pela alta emissão de poluentes.

Portanto, define-se "Poluição Atmosférica" $\rightarrow$ como as mudanças da atmosfera susceptíveis de causar impacto a nível ambiental ou de saúde humana, através da contaminação por gases, partículas sólidas, etc.

\subsection{Trabalhando com o jogo didático (Palavra Cruzadas) - Identificando a} evolução conceitual dos alunos

No jogo didático "Palavras Cruzadas" servirá para avaliar os conceitos de: Poluição Atmosférica, Poluição Antropogênica, Nomenclatura de Óxidos, Chuva ácida, Poluente Primário, Poluente Secundário, Óxidos. Será distribuído para cada grupo uma folha de papel ofício com as palavras cruzadas. Os grupos deverão preencher as lacunas verticais e horizontais de acordo com as dicas numéricas apresentadas, de acordo com o jogo abaixo. 
(1) Primário $\rightarrow$ Como é considerado um poluente diretamente introduzido no meio ambiente.

(2) Antropogênica $\rightarrow$ Poluição causada pelo homem.

(3) Trióxido de Enxofre $\rightarrow$ Nome do composto $\mathrm{SO}_{3}$

\section{VERTICAIS}

(4) Poluição atmosférica $\rightarrow$ refere-se a mudanças da atmosfera susceptíveis de causar impacto a nível ambiental ou de saúde humana, através da contaminação por gases, partículas sólidas, etc.

(5) Óxido de Zinco $\rightarrow$ Nome do composto $\mathrm{ZnO}$

(6) Óxido $\rightarrow$ São compostos formados por dois elementos, no qual o Oxigênio é o mais eletronegativo.

(7) Secundário $\rightarrow$ Como é considerado um poluente formado pela reação química de outras espécies no meio ambiente.

(8) Ácida $\rightarrow$ Chuva com elevado teor de acidez provocada pela forte concentração de óxidos de enxofre e nitrogênio, principalmente.

(9) Monóxido de Carbono $\rightarrow$ Nome do composto CO.

Figura 1 - Jogo das "Palavras Cruzadas" para Óxidos

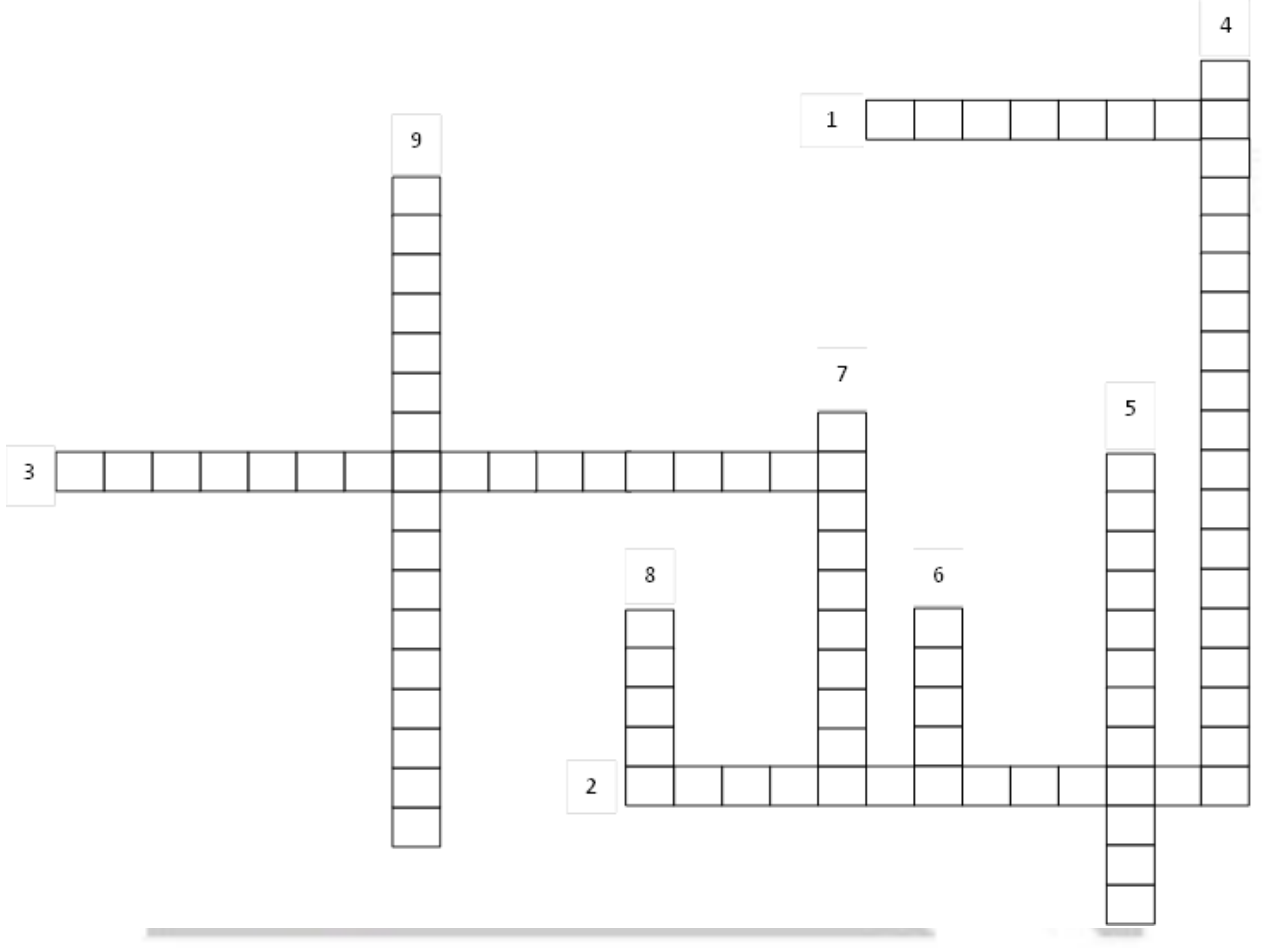




\subsection{Aplicação do Experimento Intitulado "Produção de Chuva Ácida"}

\section{Retomando o texto:}

Dióxido de nitrogênio, dióxido de enxofre lançados na atmosfera em grandes concentrações quando entra em contato com a humidade do ar pode produzir ácido nítrico e ácido sulfúrico, respectivamente.

Da leitura do texto: Altas emissões de poluentes na atmosfera poderá levar a formação de chuva ácida?

\subsubsection{Realizando os Experimentos Didáticos}

SIMULANDO A PRODUÇÃO DE CHUVA ÁCIDA

PROBLEMA: Será que podemos produzir chuva ácida a partir de materiais alternativos?

HIPÓTESE: O enxofre ao entrar em combustão ele reage com o oxigênio presente na atmosfera para formar um óxido que posteriormente reage com a água formando um ácido.

MATERIAIS:

- Tampas de garrafa pet;

- 1 Béquer;

- 2 Copos de plástico;

- Solução de hidróxido de sódio $\mathrm{NaOH}$;

- Enxofre em pó;

- Pétalas de flores;

- Palito de fósforo;

- Solução aquosa de repolho roxo;

- Fenolftaleína;

- Conta-gotas.

\section{TESTANDO A HIPÓTESE:}

- Coloque um pouco de enxofre dentro da tampa da garrafa pet;

- Coloque $10 \mathrm{ml}$ da solução de hidróxido de sódio em um pequeno copo e adicione 3 gotas de fenolftaleína com o conta-gotas e, em outro copo coloque $10 \mathrm{ml}$ da solução de repolho roxo;

- Coloque os dois copos, as pétalas e a tampa contendo o enxofre um ao lado do outro;

- Com o fósforo aqueça o enxofre até que se inicie a combustão, que é visível pelo aparecimento de uma chama violeta. Tampe imediatamente o sistema com o béquer e 
verifique se o enxofre realmente está queimando. Aguarde a queima ser completada por cerca de 5 minutos. Observe e faça as anotações necessárias;

- Em seguida verifique o que aconteceu com a pétala, com a solução de repolho roxo e com a solução de hidróxido de sódio. Anote os resultados.

\section{ENTENDENDO O EXPERIMENTO}

No processo da formação da chuva ácida, existem três principais gases que são normalmente rotulados como mais importantes, o $\mathrm{CO}_{2}, \mathrm{NO}_{2}$ e $\mathrm{SO}_{2}$. Todos são óxidos ácidos encontrados na natureza, mas o aumento de suas concentrações se dá principalmente devido à presença do homem na natureza. Pretende se mostrar com este experimento que a presença do $\mathrm{SO}_{2} \mathrm{com}$ a água produz uma solução ácida.. Para formação do $\mathrm{SO}_{2}$ ocorre conforme ilustra a equação química abaixo

$$
\mathrm{S}+\mathrm{O}_{2} \rightarrow \mathrm{SO}_{2}
$$

O óxido produzido $\left(\mathrm{SO}_{2}\right)$ em contato com a água forma uma solução ácida segundo a equação química.

$$
\begin{aligned}
& \mathrm{SO}_{2}+\frac{1}{2} \mathrm{O}_{2} \rightarrow \mathrm{SO}_{3} \\
& \mathrm{SO}_{3}+\mathrm{H}_{2} \mathrm{O} \rightarrow \mathrm{H}_{2} \mathrm{SO}_{4}
\end{aligned}
$$

Portanto, o $\mathrm{SO}_{2}$ produzido pode ser considerado como um óxido ácido, desta forma, conceitua-se um óxido ácido $\rightarrow$ como sendo aqueles que reagem com água para formar um ácido. Os óxidos de elementos dos não metais geralmente são óxidos ácidos.

O ácido produzido reage com base, formando sal e água, conforme a equação química abaixo.

$$
\mathrm{H}_{2} \mathrm{SO}_{4(\mathrm{aq})}+2 \mathrm{NaOH}_{(\mathrm{aq})} \rightarrow \mathrm{Na}_{2} \mathrm{SO}_{4(\mathrm{aq})}+2 \mathrm{H}_{2} \mathrm{O}_{(\mathrm{l})}
$$

Definindo ácido de Arrhenius partindo do ácido produzido no experimento.

Define-se ácido de ARRHENIUS como toda substância que dissolvida em água libera exclusivamente íons $\mathrm{H}^{+}$, de acordo com a equação química abaixo.

$$
\mathrm{H}_{2} \mathrm{SO}_{4 \text { (conc.) }} \rightarrow 2 \mathrm{H}_{(\mathrm{aq})}^{+}+\mathrm{SO}_{4(\mathrm{aq})}^{2-}
$$

Discussão do que é Chuva ácida:

Chuva com elevado teor de acidez provocada pela forte concentração de óxidos de enxofre e nitrogênio, principalmente.

Problemas ambientais causados pela chuva ácida: 


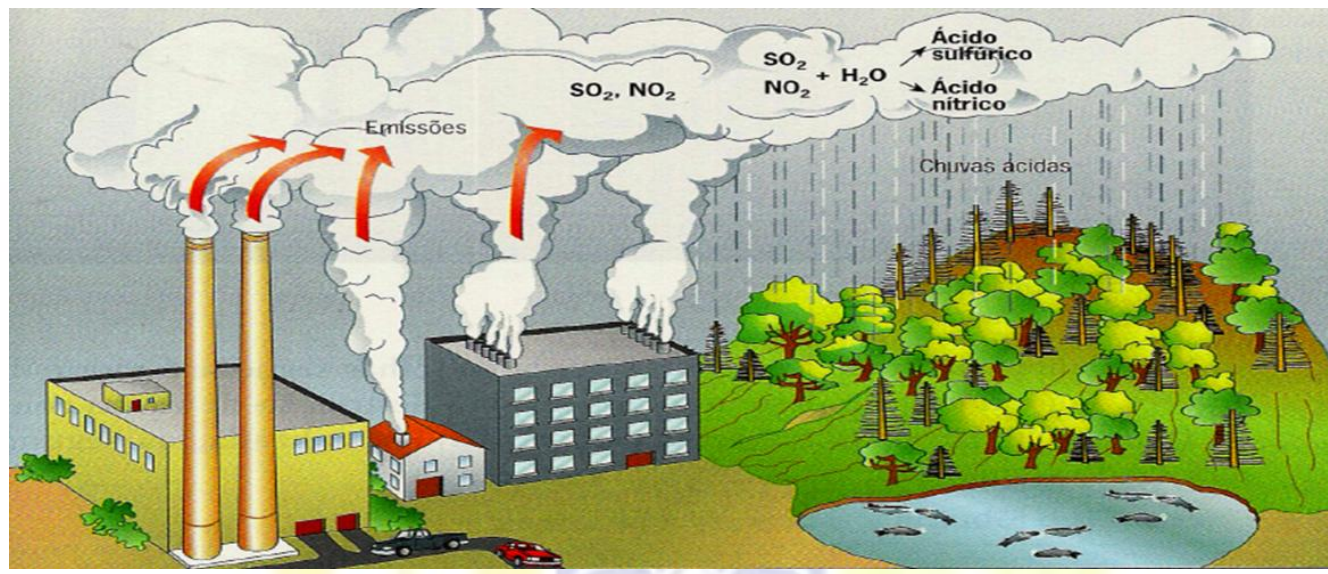

Os óxidos também podem apresentar caráter básico e neutro, desta forma, conceitua-se um óxido básico $\rightarrow$ como sendo aqueles que reagem com água para formar uma base. E os óxidos NO e CO não reagem com água, bases ou ácidos, portanto, chamados óxidos neutros.

\subsection{Trabalhando com o Jogo Didático/TRILHA QUÍMICA - Identificando} a Evolução Conceitual dos Alunos

Decorrido todo o experimento e analisado os dois primeiros parágrafos do texto didático, aplicar-se-á um jogo didático "Trilha Química" que contem conceitos químicos referentes a Óxido como critério de avalição.

\section{TRILHA QUÍMICA}

A trilha química é um jogo de perguntas e respostas. Pode ser utilizado para revisar conteúdos já trabalhados com os alunos. $O$ jogo segue uma trilha através de um tablado composto por sete casas. Cada cor representa uma pergunta que deve ser respondida pelo chefe da equipe. O jogo é composto por 20 cartas com perguntas distribuídas aleatoriamente. Vence a equipe que conseguir chegar primeiro no topo do tablado.

Objetivo

Revisar conteúdos já desenvolvidos em sala de aula.

Conteúdos

Funções Inorgânicas, com ênfase em Óxidos e Ácidos.

Número de jogadores

Cinco equipes divididas entre os alunos presentes em sala de aula, sendo um deles o chefe da equipe. 


\section{Regras}

Será ilustrado com a projeção de Datashow um tablado com todas as equipes presentes. Cada equipe terá a oportunidade de escolher uma das 17 perguntas contidas no jogo para que todas as equipes respondam, no final da escolha da última equipe, voltará à vez para a primeira equipe, seguindo-se assim até que o jogo termine. Será concedido um tempo de cinco minutos para que os grupos respondam a pergunta selecionada pela equipe em pedaços de papel ofício, logo após haverá a análise por parte do professor para verificar se a questão está certa ou errada. Avança uma casa a equipe que acertar a pergunta. Vencerá o jogo aquela que chegar primeiro na última casa.

\section{PERGUNTAS DO JOGO TRILHA QUÍMICA}

1. Todo composto binário que contém oxigênio é considerado um óxido? Justifique sua resposta.

2. A emissão de altas concentrações de óxidos emitido na atmosfera pode gerar que tipo de produto?

3. Cite dois impactos ambientais causados pela poluição atmosférica?

4. Cite duas propriedades químicas que um óxido pode apresentar?

5. O que é chuva ácida?

6. Exemplifique a formação da chuva ácida com uma equação química?

7. Defina óxido neutro?

8. Exemplifique uma reação de um óxido básico na presença de água através de uma equação química?

9. Exemplifique uma reação de um óxido ácido na presença de água através de uma equação química?

10. Quais as principais fontes emissoras de óxidos?

11. Por que a chuva ácida pode levar a morte dos peixes?

12. Qual a fórmula molécula do dióxido de carbono?

13. O composto $\mathrm{OF}_{2}$ pode ser considerado como um óxido? Justifique.

14. Justifique uma atitude que o grupo praticaria para minimizar os impactos ambientais causados pela poluição atmosférica?

15. Qual o nome do composto FeO?

16. Qual o nome do composto $\mathrm{Fe}_{2} \mathrm{O}_{3}$ ?

17. Qual o nome do composto $\mathrm{Na}_{2} \mathrm{O}$ ?

18. Qual a fórmula molécula do trióxido de enxofre? 
Figura 2 - Tablato para o Jogo Trilha Química

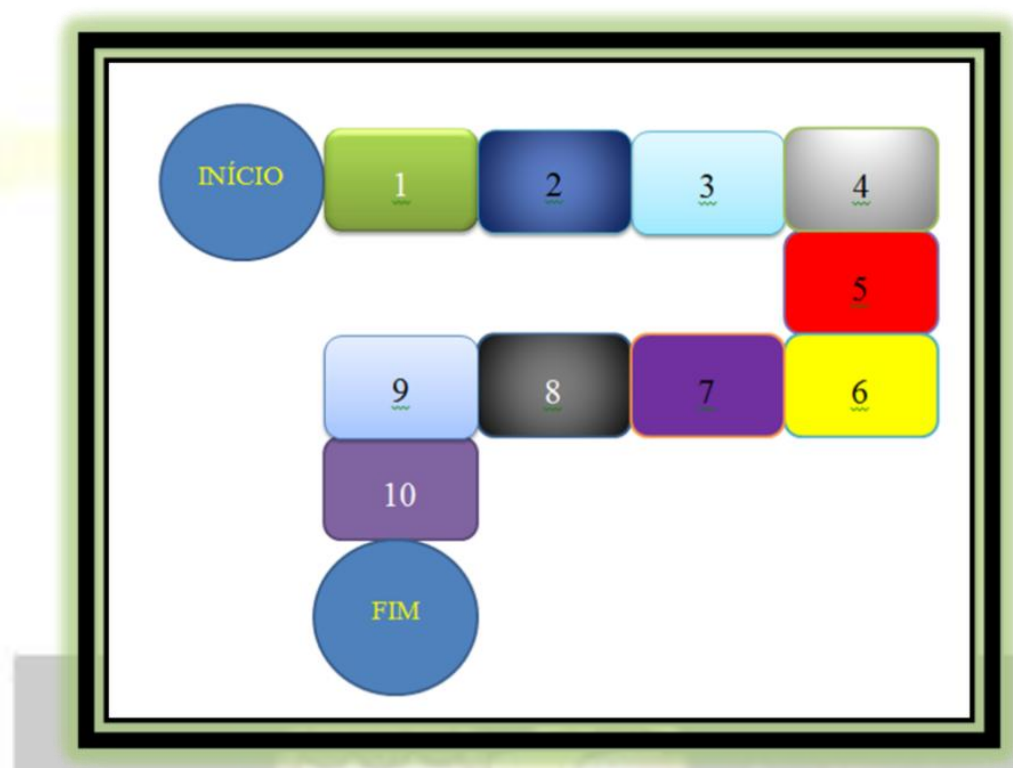

\subsection{Utilização de Vídeo Didático para Discussão de Questões Sociais Envolvendo o Terceiro e Quarto Parágrafo do Texto Didático}

3o e 4ㅇ Parágrafos

3 § - Apesar de várias iniciativas governamentais e não governamentais, impactos ambientais de diversas magnitudes vêm ocorrendo e podem se agravar em razão desse problema. $O$ velho paradigma de que não há desenvolvimento sem que haja agressões bruscas ao meio ambiente é o principal responsável por esta questão.

4ㅇ § - Há menos de cinco décadas, o discurso dos ambientalistas era tido como exagero ou ponto de vista radical e infundado. Entretanto, é fato que, por exemplo, os teores de gás carbônico na atmosférica aumentam anualmente em torno de $0,5 \%$, a temperatura média da

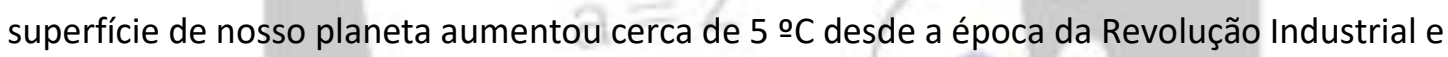
camadas inteiras e gigantescas de gelo das regiões polares são derretidas em velocidade assustadora como consequência da poluição do ar.

Neste momento haverá a exposição de um vídeo didático onde ocorrerá a discussão de questões sociais.

Poluição Atmosférica - 4 minutos e 30 segundos.

Extraído do link $\rightarrow$ http://www.youtube.com/watch?v=4EsVghlVabw

Ponto extraído do texto: "Às alterações climáticas, à diminuição da qualidade do ar pode ser nociva à saúde humana. Assim sendo, a poluição atmosférica afeta o sistema respiratório podendo agravar ou mesmo provocar diversas doenças crônicas tais como a asma, infecções 
nos pulmões, dentre outras". Além desses problemas já comprovados na saúde, estudos recentes mostram que o aumento da poluição atmosférica pode diminuir a quantidade real de proteínas em alimentos segundo matéria divulgada, em periódico da "Nature Climate Change", por pesquisadores da Universidade da Califórnia, nos Estados Unidos. Parte da matéria publicada segue abaixo na íntegra.

"Um estudo feito em campos de trigo mostrou pela primeira vez que as mudanças climáticas podem comprometer a qualidade nutricional dos alimentos. Isso ocorre porque níveis elevados de dióxido de carbono na atmosfera prejudicam a absorção pelas plantas de nitrato, utilizado para a síntese de proteínas essenciais para o ser humano. Segundo os especialistas, nas próximas décadas pode ocorrer uma queda de até $3 \%$ na quantidade de proteínas disponíveis para consumo. Realizado por pesquisadores da Universidade da Califórnia, nos Estados Unidos, o estudo foi publicado no periódico Nature Climate Change neste domingo."

Extraído do link $\rightarrow$ http://veja.abril.com.br/noticia/ciencia/poluicao-atmosferica-pode-reduzirquantidade-de-proteinas-nos-alimentos

Partindo desse ponto os alunos deverão responder as seguintes perguntas:

$1^{\circ}$ ) Quais as principais ações realizadas para tentar minimizar o elevado grau de poluição causado pelo mundo inteiro?

$2^{\circ}$ ) Existe algum projeto que proíba os países a não poluírem o meio ambiente descontroladamente?

$3^{\circ}$ ) Quais os principais impactos causados a humanidade e ao meio ambiente devido ao aumento da temperatura do planeta terra?

NOTA: a depender do desenvolvimento e a discussão gerada pelo vídeo didático, se necessário for, os conceitos anteriormente trabalhados poderão ser revisados a depender das perguntas dos discentes.

Neste momento, será introduzida a importância de simples hábitos que um cidadão pode ter para minimizar os impactos ambientais e um debate sobre o Protocolo de Kyoto, com ênfase na importância da "Cota de Carbono". Como surgiu o Protocolo de Kyoto, quais os resultados esperados, os países que fizeram parte e como funciona o esquema do Protocolo.

Decorrido toda a discussão, utilizar-se-á um mapa conceitual sobre óxido como critério de avalição na qual os alunos deverão completá-lo, visto que o mesmo estará incompleto quando for entregue para equipes formadas. A depender do resultado obtido da avaliação com o mapa conceitual, verificar-se-á se o material didático é potencialmente significativo. 


\title{
UFS - Mestrado em Ensino de Ciências e matemática
}

\author{
Disciplina: O Ensino Experimental em Ciências Naturais
}

Autores: Uilde de Santana Menezes \& Maísa Pereira de Jesus

Docente: Luiz Adolfo de Mello

\section{Sequência Didática: REAÇÕES ÁCIDO-BASE}

\section{AULAS PROPOSTAS}

Propomos uma sequência de quatro aulas com um procedimento experimental, que não precisa de laboratório para ser executado, utilizando material de baixo custo, fácil de encontrar, ou seja, um experimento, que pode ser feito com pouca estrutura, tendo em vista a realidade educacional das escolas publicas. Nesta sequência será abordado conteúdo "reações ácido-base", atrelado ao tema social "Incêndio: utilização do extintor".

\section{PLANEJAMENTO}

- Questões problematizadoras relacionadas a tema social;

- Realização da experimentação;

- Extintores de incêndio

- Relação do experimento com conteúdos de química;

- Volta aos questionamentos;

- Discussão de conceitos;

- Considerações e conclusões.

$1^{a}$ AULA: 


\section{1-Questões problematizadoras/concepções prévias}

1- Para que serve um extintor de incêndio?

2- O que devemos fazer em caso de incêndio?

3-Porque existe a utilização de um determinado extintor de incêndio depende do material que está queimando?

\section{2-CONSTRUINDO UM EXTINTOR DE INCÊNDIO}

\section{1- Objetivo}

O experimento tem por objetivo a construção de um extintor de incêndio caseiro, que visa mostrar aos estudantes a importância da Química em sua vida prática.

Além disso, o experimento permite apresentar aos alunos conceitos sobre reações químicas entre ácidos e bases, empregando reagentes de seu cotidiano, como o vinagre e o bicarbonato de sódio.

\section{2-Material utilizado}

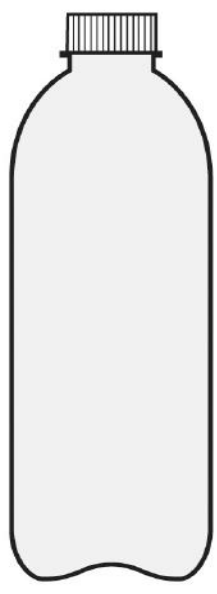

a

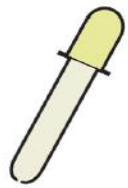

b

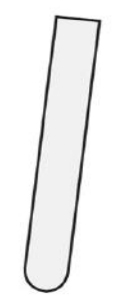

C

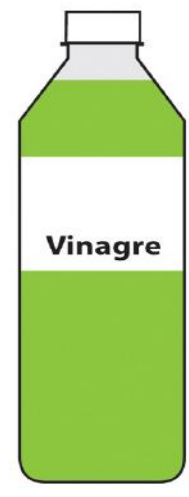

d

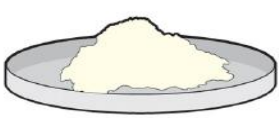

e

a- 1 frasco de refrigerante de $600 \mathrm{~mL}$ 
b- 1 tubo de conta-gotas

c- 1 tubo de ensaio de $35 \mathrm{~mL}$

d- $450 \mathrm{~mL}$ de vinagre

e- bicarbonato de sódio ( $\mathrm{NaHCO} 3)$

\section{3-Procedimento}

1. Com o auxílio de um estilete, fure a tampa do frasco de refrigerante de $600 \mathrm{~mL}$, no mesmo diâmetro do tubo do conta-gotas que será utilizado. A seguir, introduza o tubo do conta-gotas no orifício criado na tampa do frasco de refrigerante, como ostra a figura 1. O furo feito na tampa deve permitir que o tubo do conta-gotas passe o mais justo possível, visando evitar vazamentos que podem prejudicar o experimento, devido à perda de reagentes. $\mathrm{O}$ tubo do conta-gotas pode ser mais bem fixado com o uso de uma fita de teflon ao seu redor, antes de inseri-lo na tampa.
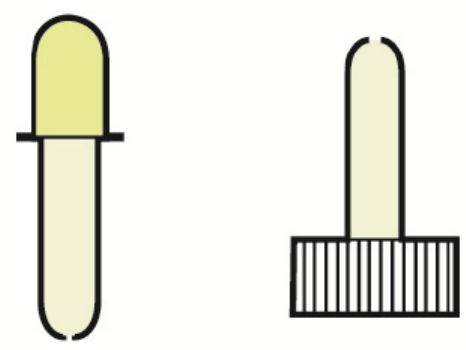

Figura 1- Tampa do frasco com conta-gotas adaptado.

2. No frasco de refrigerante, coloque $450 \mathrm{~mL}$ de vinagre comum e, no tubo de ensaio, adicione o bicarbonato de sódio de modo que o vinagre fique $2 \mathrm{~cm}$ abaixo da borda do tubo, como mostra a figura 2. 


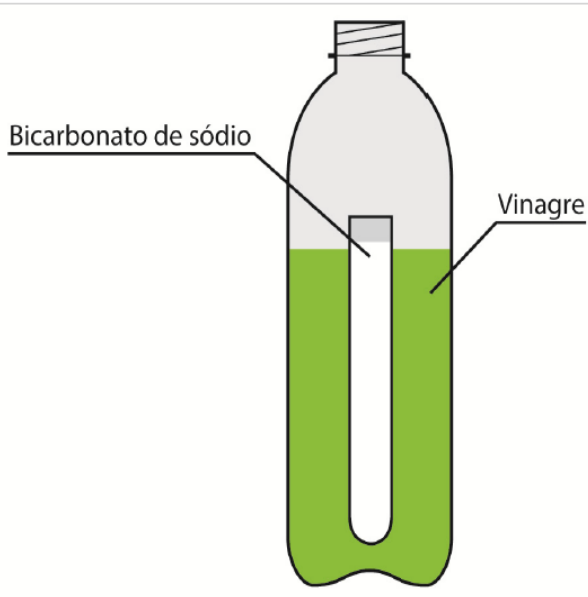

Figura 2- Frasco de refrigerante com vinagre e tubo de ensaio com bicarbonato de sódio.

Tenha cuidado para que o bicarbonato de sódio não entre em contato com o vinagre, pois isso dará início imediato à reação química. Em seguida, feche o frasco de refrigerante com a tampa, apertando-a bem.

3. Para o extintor entrar em funcionamento, tampe o furo de saída do contagotas com o dedo indicador e sacuda vigorosamente o extintor, no intuito de provocar a reação química entre o vinagre e o bicarbonato de sódio.

4. Em seguida, incline o extintor para baixo, dirigindo-o para a região que você deseja atingir e tire o dedo da tampa, liberando assim a saída do líquido.

A mistura de água e etanoato (acetato) de sódio será "expulsa" do extintor devido à pressão provocada pela formação do dióxido de carbono (CO2). Para as quantidades de vinagre e bicarbonato de sódio utilizadas, o jato inicial do líquido emitido pelo extintor terá um alcance aproximado de três metros de distância. Mantendo-se o extintor inclinado para baixo, como mostra a figura 3,o líquido continuará a ser expelido durante aproximadamente 30 segundos. 


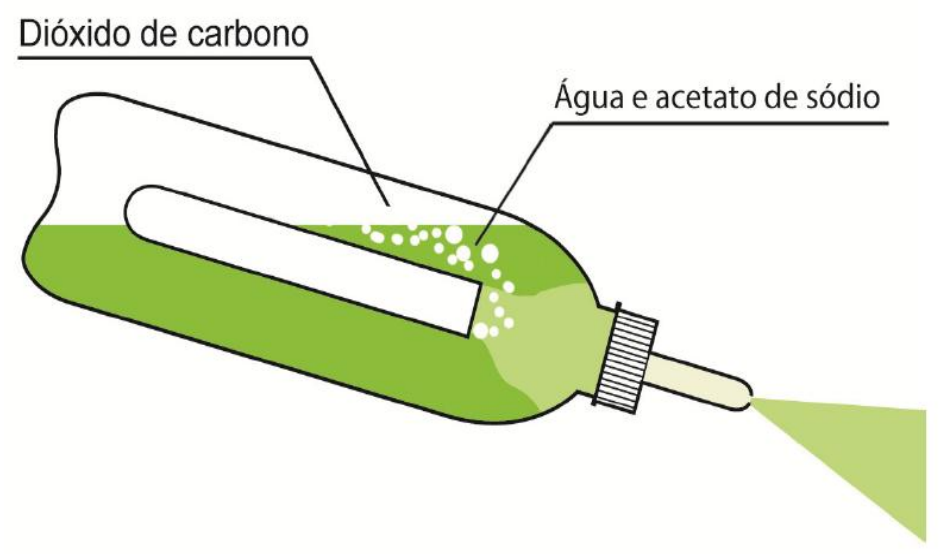

Figura 3- Utilização do extintor de incêndio.

\section{2a AULA:}

\section{1-Texto: Extintores de incêndio}

Incêndios podem ser definidos como a presença de fogo em local não desejado. São capazes de provocar, além de prejuízos materiais, quedas, queimaduras e intoxicações por fumaça.

O fogo, por sua vez, é resultante de uma reação química em cadeia, e para que esta reação ocorra são necessários:

- Material oxidável (combustível);

- Material oxidante (comburente);

- Fonte de ignição (energia) e

- Reação em cadeia.

$\checkmark$ Combustível é o material oxidável (sólido, líquido ou gasoso) capaz de reagir com o comburente numa reação de combustão; 
$\checkmark$ Comburente é o material gasoso (em geral o oxigênio) que pode reagir com um combustível, produzindo assim a combustão;

$\checkmark$ Ignição é o agente que dá o início do processo de combustão, é a energia mínima inicial necessária introduzida na mistura combustível/comburente;

$\checkmark$ Reação em cadeia é o processo de sustentabilidade da combustão, pela presença de radicais livres que são formados durante o processo de queima do combustível.

É de extrema importância conhecer e identificar bem o incêndio que se vai combater, antes de escolher o agente extintor (equipamento de combate ao fogo). Um erro na escolha de um extintor pode tornar inútil o esforço de combater as chamas, podendo até piorar a situação: aumentar ou espalhar ainda mais as chamas, ou criar novas causas de fogo (curtos-circuitos).

Os principais tipos de extintores são os seguintes:

1. Extintor H2O: água na forma líquida (jato ou neblina);

2. Extintor à base de Espuma: espuma mecânica;

3. Extintor de Gases e vapores inertes: gás carbônico (CO2), Nitrogênio, Vapor d'água;

4. Extintor Pó químico: bicarbonato de sódio.

Classes de incêndio:

A - Materiais sólidos fibrosos, tais como: madeira, papel, tecido, etc. que se caracterizam por deixar, após a queima, resíduos como carvão e cinza. Essa classe de incêndios deve ser combatida com extintores de $\mathrm{H} 2 \mathrm{O}$ ou de Espuma;

B - Líquidos e gases inflamáveis, ou em sólidos que se liquefazem para entrar em combustão: gasolina, GLP, parafina, etc. Neste caso NÃO se pode usar extintores à base de água;

C - Equipamentos elétricos energizados: motores, geradores, cabos, etc. Extintores de pó químico e de Gases são os permitidos para esse tipo de incêndio. 


\section{1-Relação do experimento com conteúdos de química}

Reações ácido-base fazem parte do nosso cotidiano. Entre vários exemplos, podemos citar: os aspectos relacionados à higiene, como a eliminação dos resíduos ácidos, deixados pelos alimentos em nossa boca, pelas pastas de dentes que possuem caráter básico; na ação dos antiácidos, tais como os hidróxidos que são usados contra a acidez estomacal e na correção da acidez do solo, para fins agrícolas.

A equação química responsável pelo jato observado produz etanoato de sódio (acetato de sódio) e ácido carbônico, o qual se decompõe em água e dióxido de carbono (gás carbônico, $\mathrm{CO} 2$ ):

\section{$\mathrm{H3CCOOH}(\mathrm{aq})+\mathrm{NaHCO}_{3}(\mathrm{~s})$-----------> $\mathrm{H}_{3} \mathrm{CCOO}-\mathrm{Na}+(\mathrm{s})+\mathrm{CO}_{2}(\mathrm{~g})+\mathrm{H}_{2} \mathrm{O}(\mathrm{l})$ \\ O gás produzido na reação aumenta a pressão interna do extintor e, sendo esta} maior do que a pressão externa, a água e o sal formados na reação são expelidos para fora do extintor. O extintor só pode ser empregado quando o fogo estiver em um nível inferior ao do frasco com a mistura reacional, pois é necessário que o gás carbônico "empurre" a água e o sal formados na reação para fora do extintor.

Visando mostrar a importância do experimento, podemos comentar sobre as classes de incêndio: A (materiais que queimam em profundidade e superfície, como madeira, papel, etc.); B (líquidos que queimam na superfície, como gasolina, álcool, etc.); C (aparelhos elétricos e eletrônicos energizados, como computadores, etc.) e D (materiais que requerem extintores específicos, como sódio, magnésio, etc.). Este extintor é exclusivo para a classe $\mathrm{A}$, mas pode ser empregado na classe $\mathrm{C}$ desde que os aparelhos incendiados não estejam ligados à rede elétrica.

Pode-se também orientar os estudantes quanto à importância da prevenção de incêndios, como a criação de brigadas de incêndios, colocação de sensores de fogo em ambientes e recomendações quanto aos cuidados sobre a evacuação de locais fechados em casos de incêndios.

\section{$4^{\text {a }}$ AULA:}

\section{1-Volta as questões problematizadoras}




\section{2-Discutindo conceitos:}

- Ácido

- Base

- Reação química

- Reações ácido-base

\section{3-Conclusões e considerações}

4-Aplicação de um questionário

\section{REFERÊNCIAS}

FERREIRA, L. H., Hartwig, D. H., Rocha-Filho, R. C. Algumas experiências simples envolvendo o princípio de Le Chatelier. v. 5, Química Nova na Escola: 1997.

QUÍMICA, Sociedade Brasileira. A Química perto de você: experimentos de baixo custo para sala de aula do ensino fundamental e médio. São Paulo: Sociedade Brasileira de Química, 2010.

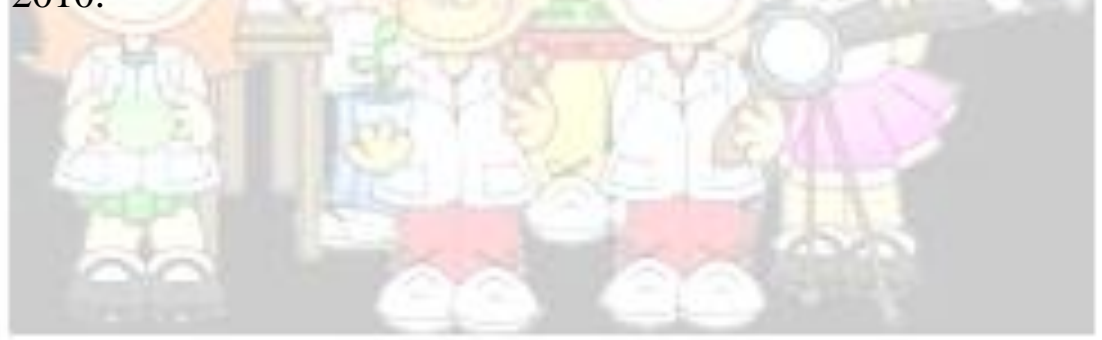

ENIERWEWTACAC, ICGCSESHWLLACCES

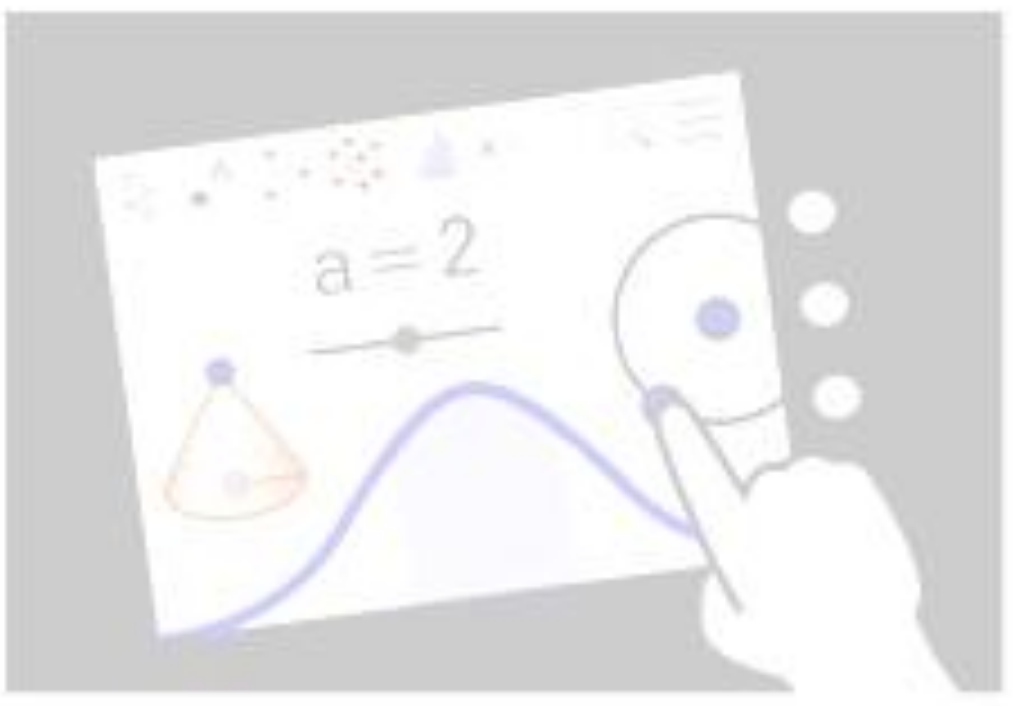




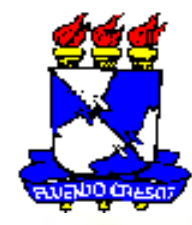

UNIVERSIDADE FEDERAL DE SERGIPE

PRÓ-REITORIA DE PÓS-GRADUAÇÃO E PESQUISA

PROGRAMA DE PÓS-GRADUAÇÃO EM ENSINO

DE CIÊNCIASE MATEMÁTICA - NPGECIMA

O ENSINO EXPERIMENTAL DE CIÊNCIAS NATURAIS

Autores: Alan Marcos da Silva Rezende \& Jefferson dos Santos Ferreira

Prof. : : Luiz Adolfo de Melo

\section{Sequência Didática: Determinação da Área de Regiões Desmatadas.}

Título: Determinação da área de regiões desmatadas.

Conteúdo a ser explorado: Cálculo de área de polígonos.

Duração: 1 hora e 40 minutos.

Abrangência: $6^{\circ}$ ano

Recursos: Imagem da região desmatada, régua e software Geogebra.

Objetivo: Calcular área de polígonos.

\section{Procedimentos:}

$1^{0}$ Momento: Inicialmente a turma será dividida em grupos com uma média de 4 alunos em cada. Em seguida, cada grupo receberá uma imagem de uma região desmatada e será feito o seguinte questionamento: "Qual a melhor maneira para calcular o total desmatado?" Eles terão 10 minutos para discutirem com suas respectivas duplas a 
respeito da melhor estratégia, provavelmente eles encontrarão a área total por meio da área de polígonos regulares.

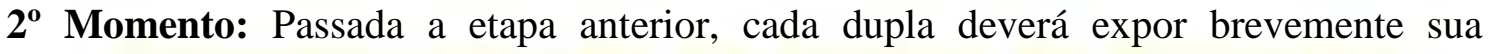
estratégia. Feito isso, eles terão mais 25 minutos para calcularem a área desmatada a partir da estratégia encontrada por eles.

$3^{\text {o }}$ Momento: Neste momento eles terão mais 10 minutos para mostrarem as soluções encontradas para a turma. Espera-se que, a depender da estratégia utilizada, os alunos obtenham resultados distintos. Eles serão questionados sobre o motivo da divergência dos resultados, caso ocorra.

$4^{\text {o }}$ Momento: Aqui, será explicado em 15 minutos algumas das ferramentas do software Geogebra que serão utilizadas no momento seguinte para a continuidade desta atividade.

$1^{\text {a } \text { ferramenta: }}$ Polígono - essa ferramenta possibilita a construção de polígonos, basta marcar no mínimo três pontos clicando com o botão esquerdo do mouse e, por fim, retornar a clicar no primeiro ponto marcado para terminar a forma geométrica desejada.

$$
\mathrm{cm}^{2}
$$

2a ferramenta: Dérea - essa ferramenta possibilita o cálculo da área da forma geométrica desejada. Para selecionar essa opção, basta expandir a referente à

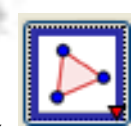
Ângulos e em seguida selecionar a opção desejada.

$5^{\circ}$ Momento: Será solicitado que os alunos utilizem as ferramentas explicadas anteriormente para calcular a área desmatada da mesma imagem do primeiro momento. Entretanto, devem repetir as formas geométricas da primeira estratégia, e para tanto eles terão 30 minutos.

$6^{\circ}$ Momento: Por fim, os alunos deverão comparar as áreas encontradas manualmente e com o auxílio do Geogebra. Se houver distinção entre elas, levantar possíveis justificativas e mostrar para o resto da turma. Para esta etapa serão destinados 10 minutos. 
Avaliação: Será de acordo com o desenvolvimento da turma durante as atividades propostas.

\section{Referência Bibliográfica}

GIOVANNI JR., José Ruy; CASTRUCCI, Benedicto. A conquista da matemática. edição renovada. $6^{\circ}$ ano. São Paulo: FTD, 2007.

TONIOLO, C. T. B. O teorema de Pick e o Geogebra: possibilidades para uma aprendizagem com significado de conceitos de geometria plana. Trabalho de Conclusão de Curso (Graduação em Matemática Licenciatura), Centro Universitário Franciscano. Santa Maria, 2010.

www.laparola.com.br, acesso em 09/07/2015.

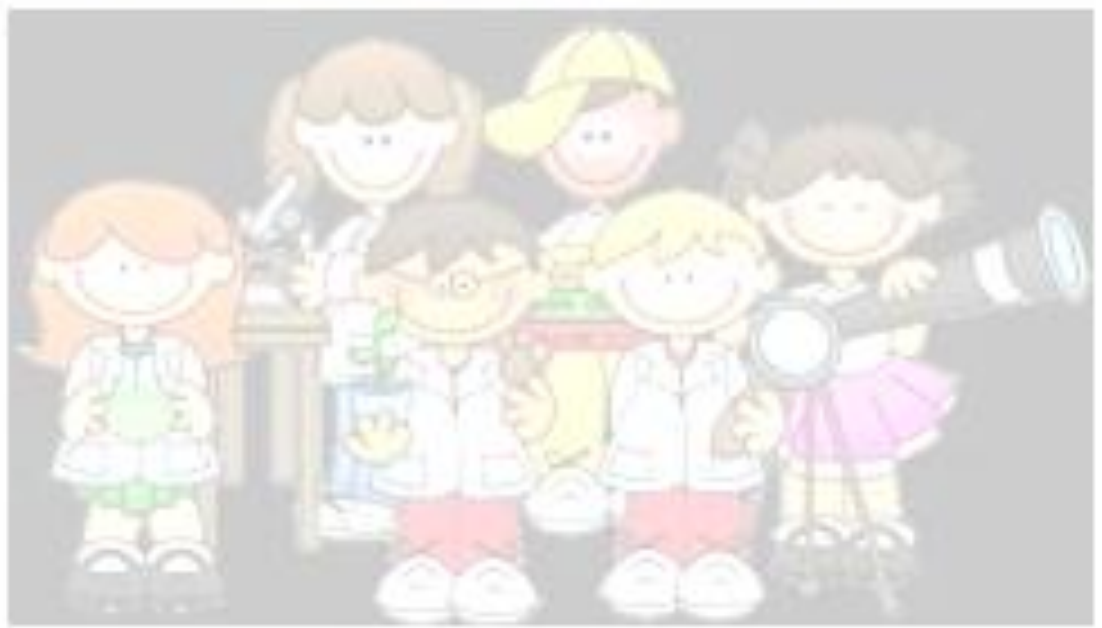

ENIERWEWTACAC, ICGCSESHWLLACCES

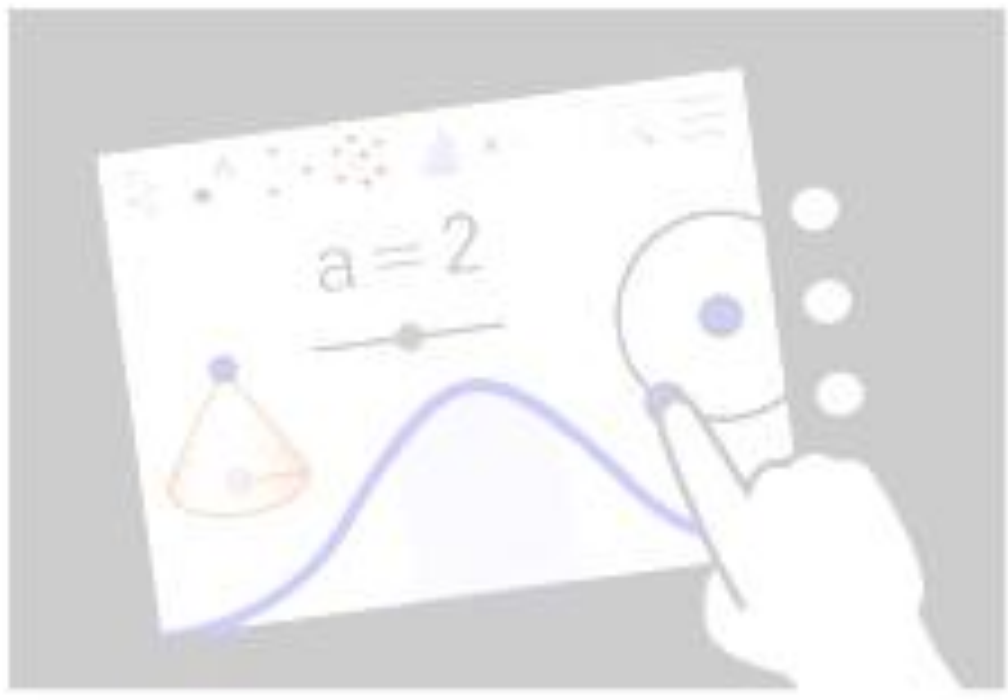


Anexo: Imagem utilizada na atividade.

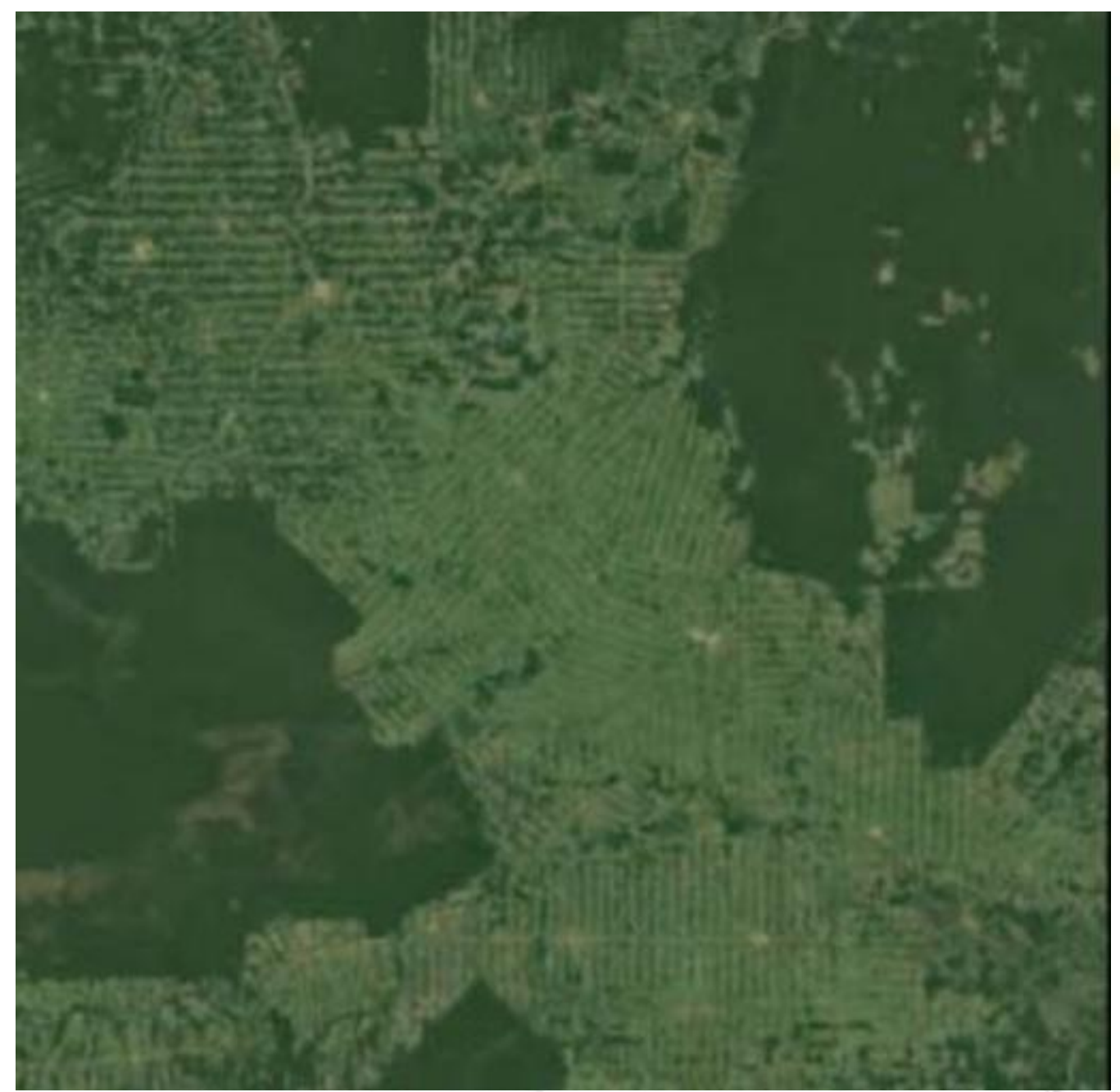

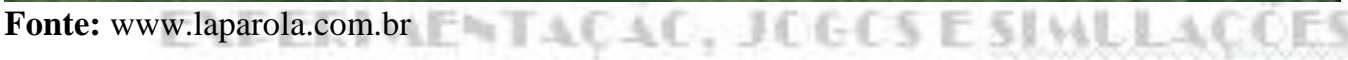

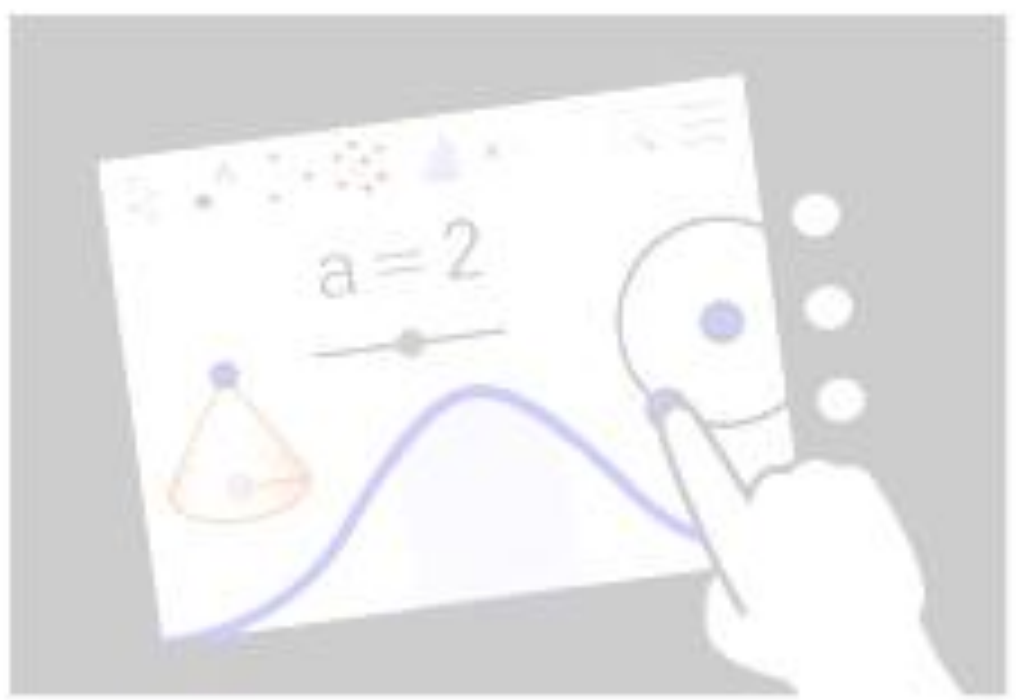




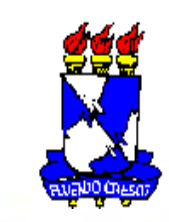

\section{Universidade Federal de Sergipe}

Núcleo de Pós Graduação em Ensino de Ciências e Matemática NPGECIMA

Mestrandas: Aline Nunes Santos e Maria Camila de Lima Brito

Docente: Luiz Adolfo

\section{Sequência Didática: Polímeros em ação}

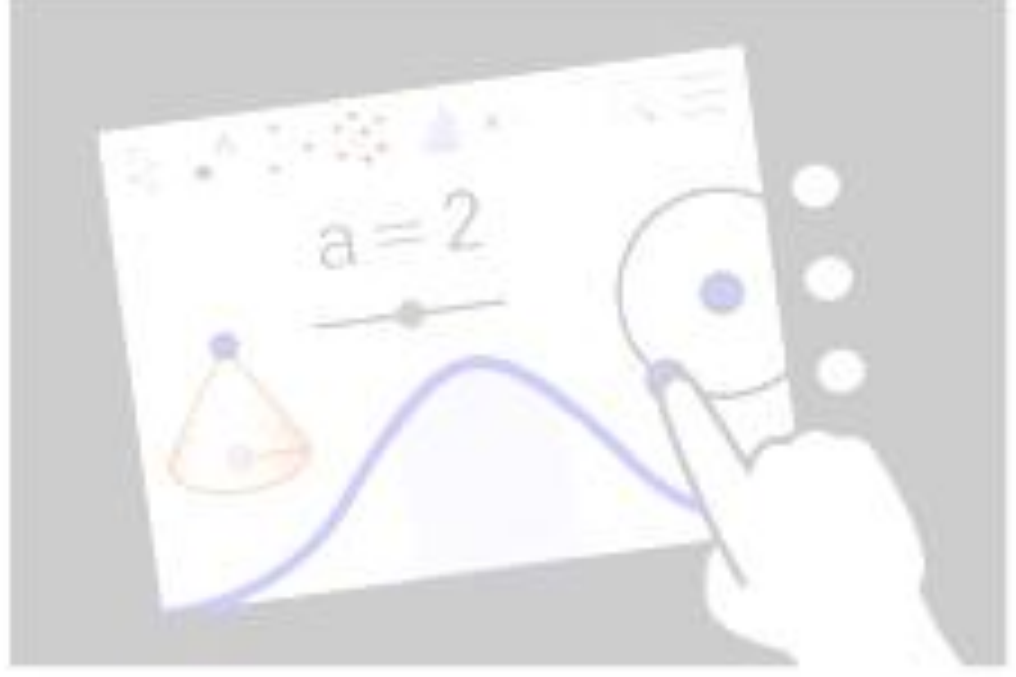

São Cristóvão - SE 
Maio/2015

\section{Planejamento de Ensino}

\section{IDENTIFICAÇÃO}

Tema Estruturador: Polímeros em ação: materiais do nosso dia-a-dia

Unidade Temática: Polímeros e suas propriedades

Disciplina: Química

Série: $3^{\circ}$ ano do Ensino Médio

\section{JUSTIFICATIVA}

Trabalhar Polímeros, envolvendo o ser humano e materiais do cotidiano no Ensino Médio, traz para os alunos, possibilidades de entendimento de como a Química está presente no nosso cotidiano e, portanto, tornar necessária a compreensão de conteúdos como meio facilitador da aprendizagem dos alunos, auxiliando-os na construção dos conceitos e do conhecimento Químico. Com isso, é importante relatar a aquisição de conceitos científicos abordando de forma acessível e significativa associando, desta forma, conteúdos científicos ao cotidiano, deixando evidente que os polímeros naturais e sintéticos pode torna-se um tema contextualizador no ensino de ciências.

\section{OBJETIVOS}

- Objetivo geral:

$\checkmark$ Compreender conceitos sobre polímeros e relacionar tais conceitos ao cotidiano.

- Objetivo Específico:

$\checkmark$ Conceituar polímeros;

$\checkmark$ Identificar as principais características dos polímeros;

$\checkmark$ Conceituar monômeros; 
$\checkmark$ Identificar as principais aplicações dos polímeros;

\section{Planejamento}

\section{Introdução}

Os polímeros estão presentes na vida de qualquer pessoa por serem de grande utilidade (doméstica ou industrial). O plástico é um dos materiais que pertence à família dos polímeros, e provavelmente o mais popular. Isto levanta uma série de perguntas.

Nesse sentido serão apresentadas algumas perguntas a fim de problematizar o tema e consequentemente gerar uma discussão sobre o assunto que será abordado.

Vamos discutir...

- De onde vem o plástico?

- Onde encontramos plástico em nosso dia a dia?

- Qual a importância do plástico para nossa sociedade?

- Por que este tipo de material é tão dominante na nossa era?

- Por exemplo, por que há baldes em plástico e não de chapa metálica ou madeira, como antigamente?

- Para que carregar um pesado balde metálico se o plástico torna o balde leve e estável o suficiente para transportar água?

\section{Resposta: Baixo peso}

- Por que os fios elétricos são revestidos de plástico e não mais de porcelana ou tecido isolante, como antigamente? 
Resposta: O revestimento plástico é mais flexível que a porcelana. Também é bem mais robusto e resistente às intempéries do que os tecidos. E tudo isso sem prejudicar o isolamento elétrico que é absolutamente vital neste caso.

- Por que as geladeiras são revestidas internamente com plástico?

Resposta: O plástico é robusto o suficiente e é um ótimo isolante térmico, exigindo menor esforço do compressor para manter os alimentos congelados.

- Por que o CD é feito de plástico?

Resposta: O plástico utilizado neste caso - policarbonato (ou, abreviadamente, $\boldsymbol{P C}$ ) - é tão transparente quanto o vidro, ao mesmo tempo que é mais leve e é bem menos frágil.

A partir desse momento de discussão com os alunos, será apresentado um vídeo da Kika "De onde vem o plástico" com o intuito de despertar a curiosidade dos mesmos. Consequentemente, será discutido sobre a descoberta dos polímeros, até a utilização do mesmo no nosso dia-a-dia, focando de início - os plásticos.

Posteriormente será realizado um experimento como eixo problematizador, a fim de estimular a curiosidade dos alunos sobre o assunto, o qual está sendo trabalhado durante a aula. Pois a realização de experimentos ajuda a aproximar a química vista na sala de aula do cotidiano dos alunos, tornando assim as aulas mais dinâmicas. Lembrando que os resultados do experimento serão discutidos durante a oficina.

\section{Materiais}

\section{Experimento I: O balão e a agulha}

$\checkmark \quad 2$ Balões de borracha (Bexiga)

$\checkmark$ Agulhas e palitos de churrasco

$\checkmark$ Rolha de cortiça

$\checkmark$ Óleo de cozinha

\section{Procedimento}


Encha os balões de borracha e solte um pouco do ar, de modo que eles não fiquem no seu tamanha máximo. Amarre-os com um nó ou com um barbante. Observe bem o balão. Existem áreas diferentes nele? Lubrifique a agulha passando um pouco de óleo de cozinha. Segure o primeiro balão e espete com a agulha na sua lateral. O que acontece? Segure o segundo balão e agora espete na região mais escura, diretamente oposta à boca do balão. O que aconteceu? Experimente fazer o mesmo na região próxima à boca do balão. Se você conseguir uma agulha fina e bem comprida você pode fazer com que ela entre próxima à boca do balão e que saia do lado oposto, sem estourar o balão.

\section{O que acontece}

A borracha é um tipo de polímero especial. Uma das propriedades mais importantes da borracha é o fato de ela ser elástica, ou seja, de tender a voltar a sua forma original quando aplicamos uma força sobre ela. Para entendermos isto, precisamos olhar como a borracha está organizada. Ou melhor, como está desorganizada!

As cadeias tendem a se alinhar em uma certa direção. Ao soltarmos a borracha, ela irá retornar à sua forma original, a não serque a força aplicada seja suficiente para romper as cadeias, e aí o polímero se rompe. Podemos tornar a borracha mais resistente ligando as diversas cadeias poliméricas. $\mathrm{O}$ processo que liga as diferentes cadeias de borracha é conhecido como vulcanização e foi descoberto por acidente por Charles Goodyear em 1839. Goodyear, um inventor americano, após experimentar com diversas combinações, estava trabalhando com misturas de borracha natural e enxofre quando, acidentalmente, derrubou a mistura em um fogão muito quente. Ao invés de jogar tudo fora e começar de novo, ele resolveu olhar as propriedades deste novo material, que agora não se tornava mais quebradiço no frio ou amolecia no calor. $\mathrm{O}$ enxofre havia formado pontes entre as cadeias poliméricas da borracha, ligando grande parte delas entre si, como uma gigantesca molécula. Agora estamos começando a poder entender por que a borracha é elástica. As cadeias poliméricas da borracha não tendem a manter as suas posições originais, e retornam ao estado anterior quando retiramos a força. Ao vulcanizarmos a borracha, estaremos fazendo com que, ao movermos as cadeias, elas tendem a retornar à posição que ocupavam, já que agora estão grudadas umas as outras.

Quando inserimos a agulha na parte mais esticada do balão ele estoura, pois as cadeias não estão relaxadas e não há espaço para que ela penetre entre as cadeias. Na 
região próxima à boca do balão e na região oposta a esta que a borracha está relaxada e pode acomodar facilmente a agulha, selando o ar no interior do balão. A borracha assume preferencialmente esta forma mais relaxada, na qual as cadeias estão completamente desorganizadas.

Um dos mais populares de borrachas, também chamadas de "elastômeros", é na preparação de gomas de mascar. As primeiras gomas de marcar foram preparadas a partir de seivas de árvore como o sapotizeiro, árvore originária da América Central, cuja goma era chamada de "chicle". Esta seiva é recolhida da árvore da mesma maneira que os seringueiros recolhem o látex, a partir de cortes no caule e colocando-se um recipiente para recolher o líquido que escorre. Os chicletes modernos têm várias composições, mas no geral se usa uma goma, normalmente sintética, como base (20\%), açúcar (63\%), xarope de milho (16\%) e 1\% de óleos que dão o sabor, como hortelã, menta ou canela. Você pode determinar qual a percentagem e polímero no seu chiclete favorito. Para isto basta você pesar o chiclete antes e depois de mascar. O polímero é o material insolúvel que resta quando todo o açúcar, xarope de milho e outros aditivos se dissolvem na boca.

Extraído do livro: Química na cabeça (p. 89-90)

\section{Experimento I: Encolhendo isopor}

\section{Materiais}

$\checkmark$ Isopor

$\checkmark$ Acetona

$\checkmark$ Frasco de vidro de boca larga ou um copo de vidro

Mãos à obra

Coloque alguns mililitros de acetona no frasco. A acetona é vendida em farmácias como removedor de esmalte, normalmente misturada com outros solventes (álcool e água). Verifique no rótulo do produto se ele contém acetona. Se você conseguir encontrar um pouco de acetona pura, poderá ver que ela funciona muito melhor. A acetona é inflamável, portanto verifique se não existem chamas nas proximidades da sua área de trabalho. Coloque um pedaço de isopor no frasco e observe. Coloque outros pedaços de isopor na acetona. $\mathrm{O}$ que acontece? O que sobrou no fundo do frasco? 
Para problematizar

O que aconteceu com o isopor?

A sua densidade é a mesma antes e depois do tratamento com a acetona?

O que é que sai na forma de bolhas?

O que acontece

O isopor é formado por um polímero conhecido como poliestireno, aquele de código de reciclagem número 6. Quer dizer que dá pra reciclar o poliesterona? Sem dúvida. Se o isopor aparece entre os plásticos de vida útil curta, pois após ser usado para embalagens ele é normalmente descartado, ele vem mudando esta imagem e já é reciclado em muitos lugares, se transformando em produtos como caixas de fitas cassetes e vasos de plantas.

Ao se fabricar o isopor, o polímero é formado na presença de um solvente com um baixo ponto de ebulição que, ao evaporar, expande o plástico, deixando o ar entrar na sua estrutura. O isopor contém cerca de $95 \%$ de ar em sua composição. É este ar no interior do isopor que o torna um excelente isolante térmico. O solvente usado inicialmente para expandir o isopor eram os clorofluorcarbonos (CFCs). Se você já ouviu falar nos problemas causados pelos CFCs em relação à camada de ozônio na estratosfera, você pode imaginar que o isopor estava na mira dos ecologistas. Atualmente os CFCs foram substituídos por solventes que não agridem o meio ambiente, como o pentano. Veja alguns exemplos dos CFCs:

E o que acontece quando colocamos a acetona? Embora alguns solventes consigam dissolver materiais poliméricos, este não é o caso com a acetona e o isopor. A acetona enfraquece as interações entre as cadeias de poliestireno, amolecendo o isopor e permitindo que o ar preso escape. Estas são as bolhas que podem ser observadas quando colocamos o isopor na acetona. Podemos recuperar o poliestireno como uma massa pegajosa no copo. Ao secar essa massa irá se tornar rígida e quebradiça. Você pode colocar este material em um molde, como por exemplo, um tubo plástico de filme fotográfico, antes de ele secar e observar o material após a acetona evaporar.

Extraído do livro: Química na cabeça (p. 84-85) 
Partindo dessa problematização e contextualização, contando com o auxílio de slides, iniciaremos a explicação tentando reaproveitar os conhecimentos abordados por eles durante a discussão das perguntas e experimento. Nessa perspectiva, discutiremos cientificamente sobre a definição de polímeros, classificação e suas propriedades.

Por fim, será realizado um Jogo Lúdico (Tabuleiro Químico) com a intenção de estimular a participação e investigar os conhecimentos dos alunos adquiridos no decorrer da aula relacionada ao conteúdo abordado, dentre outras que serão incluídas para ocasionar descontração durante a dinâmica.

\section{Jogo Lúdico: Tabuleiro Químico}

Regras do jogo

1- Formem dois grupos sendo que cada grupo apresente um capitão (representante para jogar)

2- Antes que iniciar, identifique o nome do grupo.

\begin{tabular}{|c|c|}
\hline Acertou & Errou \\
\hline $\begin{array}{l}\text { Cor da casa Vermelho- Difícil- ande } 3 \\
\text { casas. }\end{array}$ & Ande 1 casa. \\
\hline EXIERW MENTACAC, - & GCSESHWLLACOES \\
\hline Cor da casa Azul- Média- ande 2 casas. & Ande 2 casas. \\
\hline Cor da casa Verde- Fácil- ande 1 casa. & Ande 3 casas. \\
\hline
\end{tabular}

3- Cada um tem direito que jogar uma vez.

4- O vencedor ganhará um prêmio.

5- As perguntas serão distribuídas da seguinte maneira: 12 perguntas para cada grupo, sendo que das 12

> 6 são perguntas sobre o conteúdo distribuída igualmente em: fácil, média e difícil;

> 2 são informações;

> 3 descontração. 


\section{As perguntas são:}

1. O que você entende por polímeros?

2. Qual a matéria-prima para a obtenção dos plásticos?

3. O avanço no desenvolvimento de polímeros levou ao surgimento de uma subárea da Química, denominada Química dos Materiais. Nesse sentido, os polímeros podem ser classificados em três grandes grupos. Cite-os.

4. Por que os polímeros adquiriram tanta importância na sociedade atual?

5. Qual a necessidade, em termos ambientais, de conhecermos as propriedades dos polímeros?

6. Os polímeros podem receber diferentes tipos de classificações. Quanto a sua ocorrência, cite os dois tipos e diferencie.

7. Dos materiais que você usa diariamente, quantos são feitos de plásticos? Cite alguns.

8. Ao longo das últimas décadas, o material feito de plástico entrou com peso em diversos ramos industriais (construção civil, eletrônica, embalagens, móveis, etc.), substituindo o metal, vidro, cerâmica, madeira e papel. Cite algumas vantagens, as quais levaram a esse fato acontecer.

9. Baseado no experimento $\mathrm{I}$ - O balão e a agulha - Cite uma das propriedades mais importantes da borracha?

10. Sabemos que nem todos os plásticos são iguais. Desse modo, eles são classificados em dois tipos. Cite-os e diferencie um do outro?

11. Onde encontramos plástico em nosso dia a dia?

12. Qual a importância do plástico para nossa sociedade?

13. Os primeiros materiais utilizados como elementos estruturais, de proteção e na fabricação de instrumentos foram encontrados "prontos" na natureza, como pedras, madeiras, folhas de árvores etc. Foi através da observação de processos naturais que os seres humanos se inspiraram e, com algumas modificações, transformaram os materiais existentes, dando origem a materiais artificiais como cerâmica, vidro, papel, borracha, concreto etc.

14. Mas os plásticos não trazem apenas benefícios à humanidade. Em função de seu uso tão difundido, grande parte do lixo que produzimos diariamente é composta deste material. Eles se decompõem muito lentamente (alguns tipos necessitam de séculos para se degradar) e vêm acarretando sérios problemas ambientais. 
15. A palavra plástico vem do grego plásticos. Ela é empregada em várias áreas do conhecimento humano, apresentando um espectro de significados, mas em geral se refere a algo moldável. Assim, quando falamos de cirurgião plástico ou artista plástico estamos nos referindo a profissionais que tentam dar novas formas, moldar, reconstituir, modelar.

16. Durante sua longa caminhada, o ser humano vem modificando o meio em que vive. Com seu cérebro singular, pensa, observa, planeja, cria, elabora, modifica suas ideias, explica, ensina a seus descendentes, registra, e, felizmente, reflete sobre suas realizações.

17. Escolha um colega e peça para que ele(a) diga uma qualidade e um defeito seu/sua.

18. Qual disciplina você tem mais habilidade?

19. Defina a escola em três palavras?

20. Qual a importância da Química em sua vida?

21. Qual o (a) menino (a) mais gatinho (a) da sala?

\section{Referências}

PIATTI, Tânia Maria. Plásticos: características, usos, produção e impactos ambientais / Tânia Maria Piatti, Reinaldo Augusto Ferreira Rodrigues. - Maceió: EDUFAL, 2005. 51p.: il. - (Conversando sobre ciências em Alagoas) p. 10 à 16

SANTOS, Wildson Luiz Pereira dos; MÓL, Gerson de Souza (coord). Química e Sociedade: volume único, ensino médio. São Paulo: Nova Geração, 2005.

LISBOA, Julio Cezar Foschini. Química: ensino médio, volume único. $1^{\mathrm{a}}$ edição, São Paulo: Edições SM, 2010.

MATEUS, Alfredo Luis. Química na cabeça. Belo Horizonte: Editora UFMG, 2001. VÍDEO LINK KIKA

GORNI, A. A. Introdução aos plásticos. Disponível em: <http://www.gorni.eng.br/intropol.html> Acessado em 24/05/15 às 10h32min 


\section{Sequência Didática - Forças Intermoleculares a partir da Tensão Superficial}

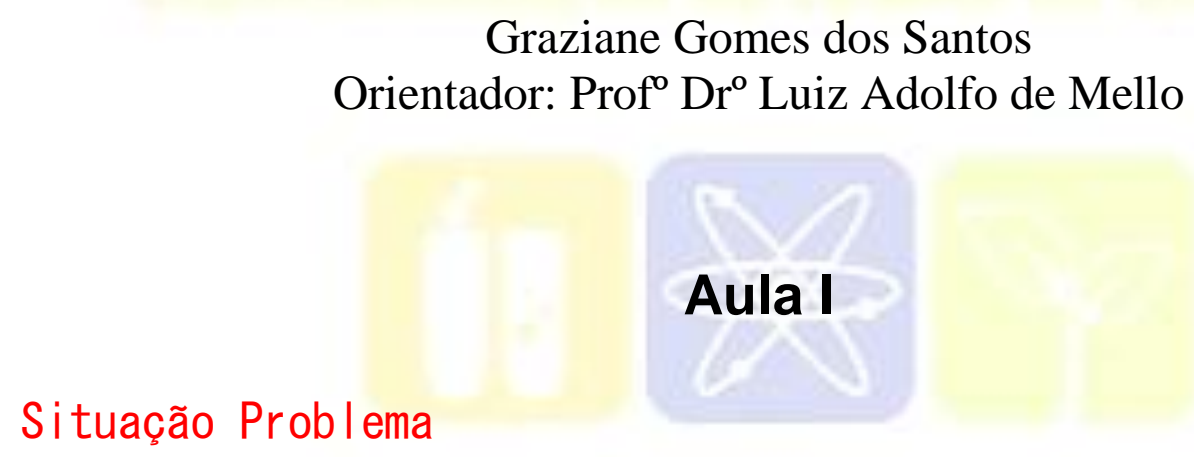

De vez em quando é preciso fazer milagres!

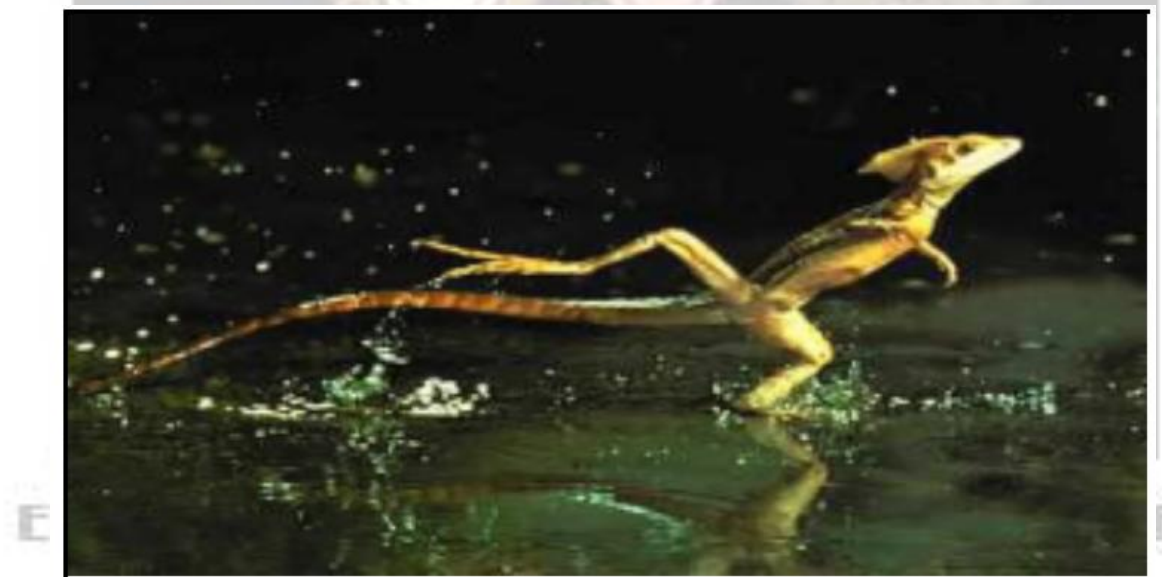

Figura 1: Lagarto Basilisco. Fonte: jornaldosbichos.blogspot.com.br. Acessado em: 20/07/2015.

Esse pequeno lagarto da foto é o Basilisco ( Basiliscus basiliscus), uma espécie encontrada comumente próximo a rios e lagos nas selvas das Américas Central e Sul. A característica que torna essa espécie muito especial dentre todas as outras espécies de lagartos e sua curiosa habilidades de correr sobre a água sem afundar, habilidade essa que lhe rendeu, inclusive o apelido em inglês de Jesus Christ Lizard ( lagarto Jesus Cristo). Só que não há nenhum milagre envolvido nessa habilidade, apenas uma combinação ótima de física dos fluídos e características fisiológicas do pequeno réptil.

De um lado temos a famosa Tensão Superficial da água, algo que leva a superfície do líquido a se comportar como se fosse uma membrana elástica. De outro temos a descoberta de que o pequeno réptil possui uma fileira de escamas ao redor de cada dedo que aumenta a área da pata, que lhe permite tirar vantagem da tensão superficial da água para correr sobre o líquido em afundar. 
Com o objetivo de propor uma maior discussão sobre o texto e os conceitos propostos acima seguem as seguintes questões.

1- Além dos aspectos contidos no texto, procure explicitar alguns fatores que julgue importante para justificar o fato do lagarto Basilisco ter essa habilidade de flutuar sobre a água sem afundar.

2- Você verificou no texto que um dos fatores que leva o lagarto Basilisco a flutuar é a tensão superficial. Você sabe o que venha ser essa tensão superficial? Em caso afirmativo, apresente sua definição.

3- No texto são apresentados características do lagarto, cite-as.

4- O que são ligações intermoleculares? Já ouvi falar?

\section{Aula II \\ Organização do Conhecimento}

Discussão das Questões

Para levantar uma discussão das questões apresentadas, vamos realizar um experimento para a análise dessa propriedade. Assim poderemos realizar um estudo dessa característica e relacioná-lo com as condições apresentadas.

\section{Experimento I: Agulha e Clipe flutuante}

Materiais

- Água;

- Agulha;

- Clipes;

- Copo transparente;

- Pinça.

Procedimento experimental

Com a ajuda da pinça coloca-se a agulha no copo cheio com água, observa-se que a mesma irá boiar no recipiente. Adicione uma gota de sabão (detergente) na água, logo, a agulha irá afundar.

Como o detergente é tensoativo, este irá fazer com que as moléculas de sabão quebrem as moléculas de água, fazendo com que a agulha afunde.

Repete-se o mesmo processo experimental com o clipe.

Sugestão: Para melhor visualização aconselha-se a utilização de corantes, afim de melhorar o entendimento.

\section{Experimento II: Barco movido a sabão}

Materiais

- Água;

- Bacia ou forma;

- Detergente;

- Folha de papel;

- Tesoura.

Procedimento experimental 
Recortá-se a folha de papel para formar um "barquinho" que vai navegar na bacia. Encha a

bacia com água e adicione pequenas gotas de detergente bem próximo ao barquinho, afim de ele saia do lugar e explore todo o oceano do recipiente.

Sugestão: Caso queira deixar mais divertido, é só adicionar corante na água.

\section{Questões-Problemas}

As questões a seguir fazem referência aos experimentos I e II.

1 - Por que o navio flutua?

2- Por que a água da chuva tem a forma esférica?

3- Por que ao adicionar o detergente a agulha/clipe afunda?

4- O que leva o barquinho a movimentar-se quando estão em contanto com o detergente?

5- Logo, qual a função do detergente?

6- Que tipos de ligações possui a água para evitar que o barquinho afunde?

7- Existe algum meio de aumentar a tensão superficial?

8- Como o agente tensoativo diminui a tensão superficial da água?

\section{Aula III e IV}

\section{Conhecimentos e Conceitos envolvidos}

\section{Estrutura e propriedades dos materiais: Forças Intermoleculares.}

A água cobre mais de $70 \%$ da superfície terrestre e é vital para toda a vida no planeta. É a substância mais abundante da natureza, ocorrendo nos rios, lagos, oceanos, mares e $\mathrm{n}$ as calotas polares. Dentre os diversos reservatórios, mais de $99 \%$ correspondem aos oceanos, às geleiras e à umidade dos solos e do ar.

O total de água doce no nosso planeta, corresponde a 40 x 1015 de litros, ou seja $3 \%$ de toda água da Terra, (os 97\% restantes são de água salgada), onde $2 \%$ fazem parte da calota glacial, esta não disponível na forma líquida. Portanto, verdadeiramente apenas $1 \%$ do total de água do planeta é de água doce na forma líquida, incluindo-se as águas dos rios, dos lagos e as subterrâneas. Estima-se que apenas 0,02 \% deste total corresponda à disponibilidade efetiva de água doce com a qual pode a humanidade contar, em termos médios e globais, para sustentar-se e atender às necessidades ambientais das outras formas de vida, das quais não pode prescindir. Dos $1 \%$ da água doce líquida disponível no planeta, $10 \%$ esta localizada em território brasileiro.

A água é considerada a mais abundante das substâncias encontradas na crosta terrestre. Nosso planeta possui um suprimento abundante de água calculado em cerca de 1392 milhões de quilômetros cúbicos de água líquida. Calcula-se que cerca de $71 \%$ da superfície da Terra encontra-se coberta de água e, deste total, 97\% são águas oceânicas.

A água é tão importante, que os gregos antigos consideravam-na como sendo um dos elementos fundamentais da matéria. Aristóteles considerava a água como um dos quatro elementos fundamentais. Por mais de 2000 anos ainda pensou-se que a água era um elemento; somente no século XVIII experimentos evidenciaram que a água era um composto, formado por hidrogênio e oxigênio. 
A água tem uma estrutura molecular simples. Ela é composta de um átomo de oxigênio e dois átomos de hidrogênio. Cada átomo de hidrogênio liga-se covalentemente ao átomo de oxigênio, compartilhando com ele um par de elétrons. $\mathrm{O}$ oxigênio também tem um par de elétrons não compartilhados. Assim, há 4 pares de elétrons em torno do átomo de oxigênio, dois deles envolvidos nas ligações covalentes com o hidrogênio e dois pares não-compartilhados no outro lado do átomo de oxigênio. Estado físico das substâncias e as forças intermoleculares

No estado gasoso, as moléculas encontram-se muito separadas uma das outras, praticamente não existem forças atrativas entre elas; por isso, os gases tendem a ocupar totalmente o recipiente que os contém. Já nos estados líquido e sólido, o que impede que as moléculas se difundam por todo o recipiente são forças atrativas entre elas Essas forças são denominadas forças intermoleculares, forças de Van der Waals ou interações de Van der Waals.

As forças podem ser intensas o suficiente para manter, por exemplo, muitas substâncias moleculares em estado sólido ou líquido, porém as forças intermoleculares são mais fracas do que as forças intramoleculares (ligações químicas), mas fortes o suficiente para governar certas propriedades das substâncias, tais como: mudança de estado físico (fusão, ebulição, sublimação etc.), tensão superficial, viscosidade, capilaridade entre outras.

\section{Interações dipolo - dipolo}

Sabe-se que as moléculas polares não apresentam distribuição uniforme de carga ao longo de sua superfície. Quando uma molécula é polar, como, por exemplo, $\mathrm{HCl}$, ela apresenta uma extremidade mais eletropositiva e outra mais eletronegativa:

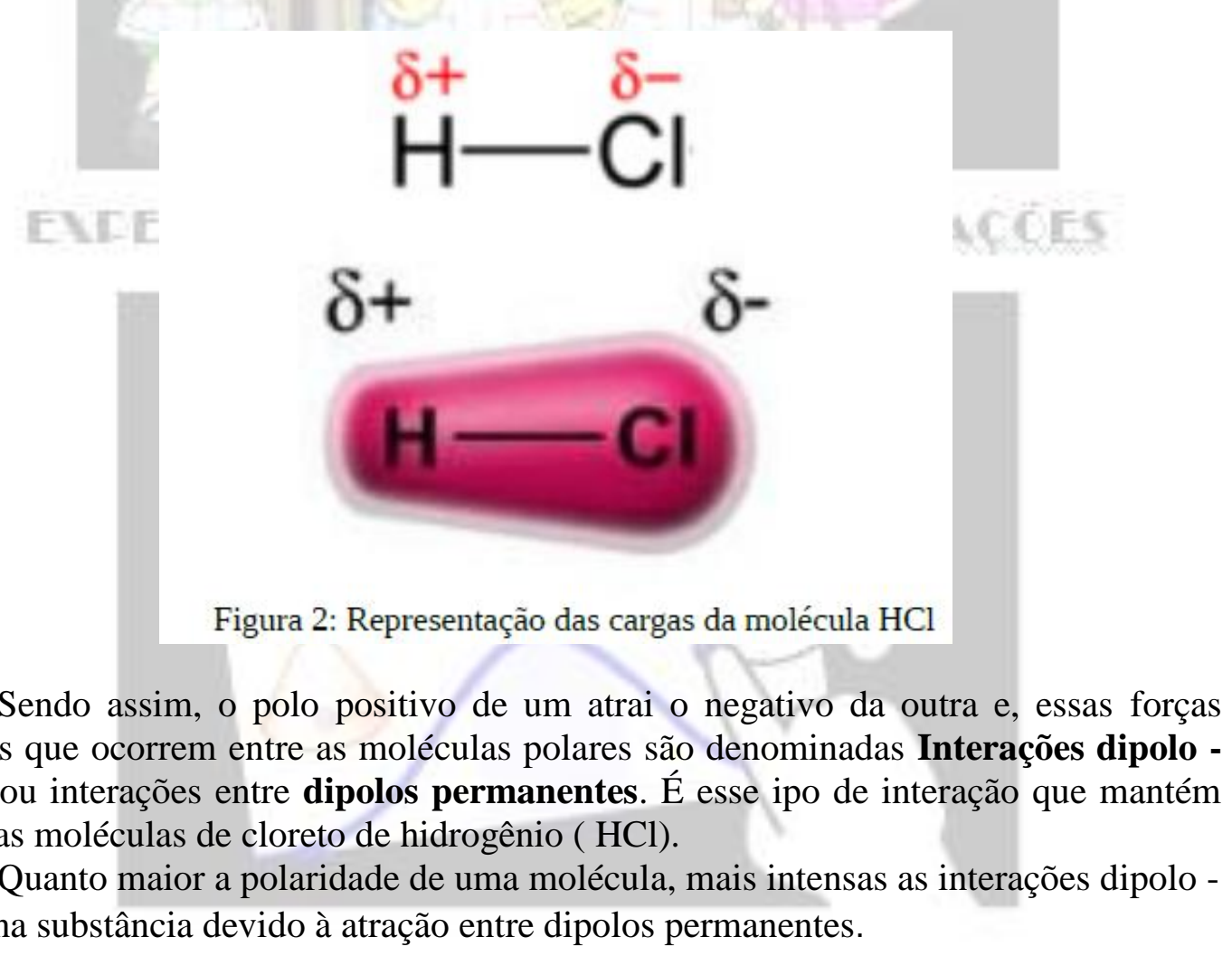

atrativas que ocorrem entre as moléculas polares são denominadas Interações dipolo dipolo ou interações entre dipolos permanentes. É esse ipo de interação que mantém unidas as moléculas de cloreto de hidrogênio $(\mathrm{HCl})$.

Quanto maior a polaridade de uma molécula, mais intensas as interações dipolo dipolo na substância devido à atração entre dipolos permanentes. 


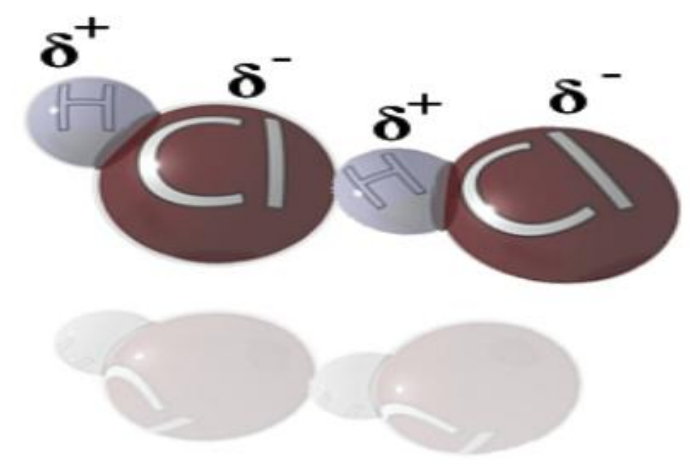

Figura 3: Representação da molécula HCL no momento da interação dipolo-dipolo

\section{Ligações de Hidrogênio}

Um caso extremo de atração dipolo-dipolo ocorre quando temos o hidrogênio ligado a átomos pequenos e fortemente eletronegativos, especialmente $\mathrm{o}$ flúor, $\mathrm{o}$ oxigênio e o nitrogênio. A forte atração que se estabelece entre o hidrogênio e esses elementos chama-se ligação de hidrogênio, e existe fundamentalmente em substâncias nos estados sólido e líquido. A ligação de hidrogênio forma um tipo especial de interação dipolo-dipolo, que é cerca de cinco vezes mais intensa que uma interação dipolo-dipolo comum.

O exemplo mais representativo das ligações de hidrogênio é o da molécula de água. No estado líquido, uma molécula de água forma ligações de hidrogênio aleatórias com as moléculas vizinhas, condizentes com o seu estado físico. Contudo, no estado sólido, cada molécula de água forma quatro ligações de hidrogênio com as moléculas mais próximas, em uma estrutura tetraédrica, que possibilitará a formação de um retículo cristalino. Nessa estrutura, a distância entre as moléculas de água é maior do que no estado líquido. Dessa forma, o número de átomos por unidade de volume, na água líquida é maior do que no estado sólido, tornando a densidade do gelo menor que a da água líquida e permitindo que aquele flutue na água.

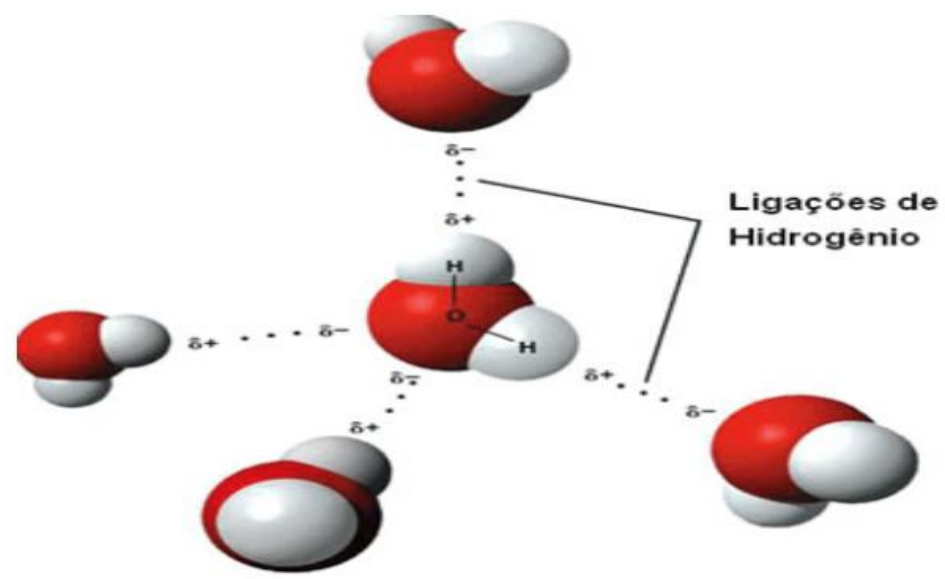

Figura 4: Representação das ligações de hidrogênios presentes na molécula de água no estado líquido

As fortes ligações de hidrogênio conferem importante propriedade às moléculas de água - alta tensão superficial . As moléculas que estão no interior do líquido atraem e são atraídas por todas as moléculas vizinhas, de tal modo que essas forças se equilibram. Já as moléculas da superfície só são atraídas pelas moléculas "de baixo" e "dos lados". 
Consequentemente, essas moléculas se atraem mais fortemente e criam uma película semelhante a uma película elástica na superfície da água (isso ocorre com todos os líquidos; apenas estamos dizendo que o fenômeno é particularmente intenso na água).

\section{Saiba mais...}

A alta tensão superficial apresentada pela água é explicada pelas ligações de hidrogênio estabelecidas entre moléculas dessa substância. Em um líquido, as forças de atração entre as moléculas de sua superfície são diferentes daquelas que atuam em seu interior. Enquanto no interior do líquido as moléculas se atraem mutuamente com as mesmas forças, as que ocupam a superfície são atraídas para o interior, pois não há moléculas de líquido acima da superfície, apenas ar ( a atração entre moléculas de água é bem maior do que a interação da água com os componentes do ar).

Como consequência, o líquido se comporta como se possuísse uma membrana elástica em sua superfície. O fenômeno da tensão superficial explica por que as gotas são arredondadas. No caso específico da água a tensão superficial é tão alta que permite que alguns insetos, como o alfaiate, andem sobre ela. O fenômeno explica também por que uma lâmina de barbear feita de aço, cuja densidade é de aproximadamente $8 \mathrm{~g} / \mathrm{cm} 3$, flutua quando colocada horizontalmente sobre a superfície da água.

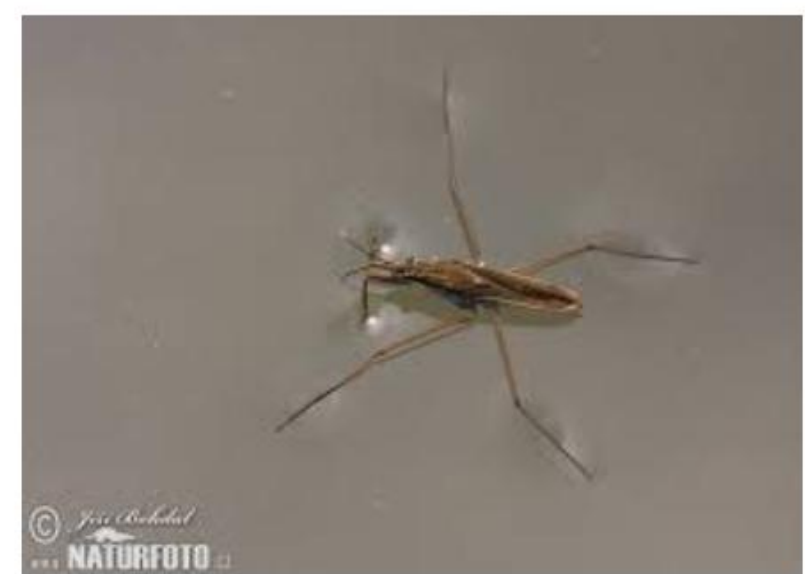

Figura 5: Inseto alfaiate flutuando sobre a água. Fonte: www.naturfoto.cz. Acessado em 20/ 07/ 2015

\section{Interações entre moléculas apolares}

Há evidências de que as moléculas de substâncias apolares estão associadas por forças de baixa intensidade. Por esse motivo é possível liquefazer gases, como o nitrogênio, N2. Essas forças de baixa intensidade também explicam existências de substâncias apolares líquidas, entre elas os hidrocarbonetos presentes na gasolina ( compostos formados por carbono e hidrogênio), e sólidas, como o iodo, I2.

As atrações que ocorrem entre moléculas apolares são denominadas interações dipolo induzido - dipolo induzido, dipolo - dipolo induzido, forças de dispersão de London, ou, simplesmente, forças de London.

As Força de dispersão de London, é uma atração que ocorre entre moléculas apolares, que quando se aproximam umas das outras, causam uma repulsão entre suas nuvens eletrônicas, que então se deformam, induzindo a formação de dipolos. Essa força é mais fraca que a do tipo dipolo - dipolo. Logo, as substâncias que apresentam esse tipo de ligação apresentam menor ponto de fusão e ebulição. Quanto maior for o tamanho da molécula, mais facilmente seus elétrons podem se deslocar pela estrutura. 
Maior é então, a facilidade de distorção das nuvens eletrônicas, e mais forte são as forças de dispersão de London. Isso faz com que a substância tenha maior ponto de ebulição.
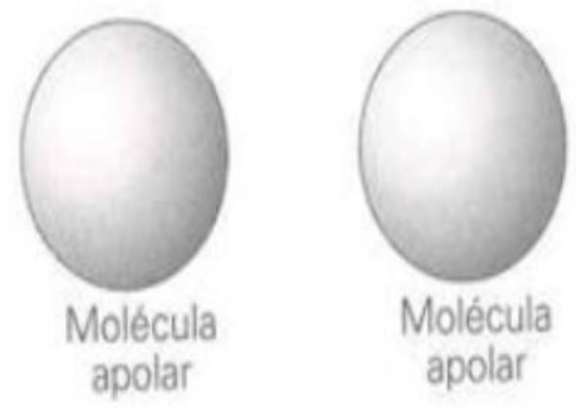
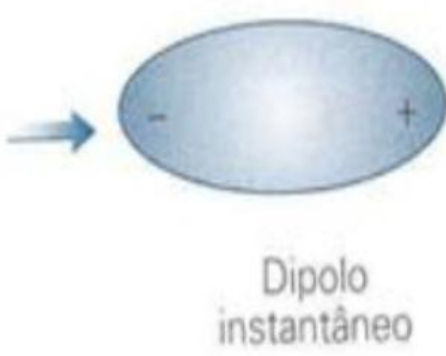

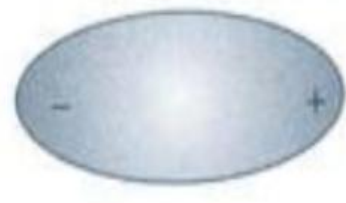

Figura 6: Representação gráfica das Forças de Lodon

Os dipolos instantâneos podem induzir a polarização de moléculas adjacentes, resultando em forças atrativas. Todas as moléculas polares e apolares, apresentam interações do tipo dipolo - dipolo induzido. Nas moléculas apolares, contudo, esse é o único tipo de interação molecular presente.

\section{Aula V \\ Aplicação do Conhecimento}

1. (FGV-SP) O conhecimento das estruturas das moléculas é um assunto bastante relevante, já que as formas das moléculas determinam propriedades das substâncias como odor, sabor, coloração e solubilidade. As figuras apresentam as estruturas das moléculas de $\mathrm{CO}_{2}, \mathrm{H}_{2} \mathrm{O}, \mathrm{NH}_{3}, \mathrm{CH}_{4}, \mathrm{H}_{2} \mathrm{~S}$ e $\mathrm{PH}_{3}$.
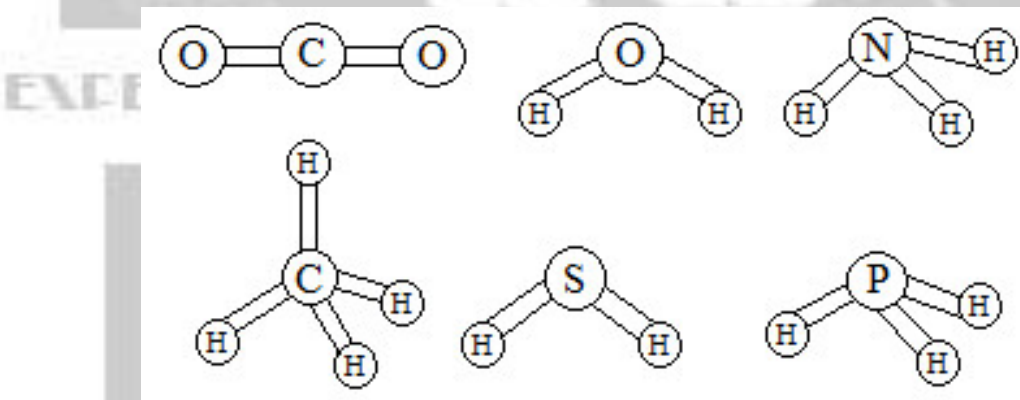

Estruturas de moléculas em exercícios sobre interações intermoleculares

Quanto às forças intermoleculares, a molécula que forma ligações de hidrogênio (pontes de hidrogênio) com a água é:
a) $\mathrm{H}_{2} \mathrm{~S}$.
b) $\mathrm{CH}_{4}$.
c) $\mathrm{NH}_{3}$.
d) $\mathrm{PH}_{3}$.
e) $\mathrm{CO}_{2}$.

2. (ENEM 2011) A pele humana, quando está bem hidratada, adquire boa elasticidade e aspecto macio e suave. Em contrapartida, quando está ressecada, perde sua elasticidade e se apresenta opaca e áspera. Para evitar o ressecamento da pele é necessário, sempre que possível, utilizar hidratantes umectantes, feitos geralmente à base de glicerina e polietilenoglicol: 
<smiles>OCC(O)CO</smiles>

glicerina

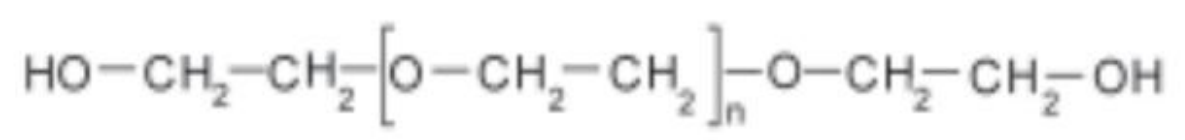

\section{polietilenoglicol}

Disponível em: http://www.brasilescola.com. Acesso em: 23 abr. 2010 (adaptado) (Foto: Reprodução/Enem)

A retenção de água na superfície da pele promovida pelos hidratantes é consequência da interação dos grupos hidroxila dos agentes umectantes com a umidade contida no ambiente por meio de:

a) ligações iônicas.

b) forças de London.

c) ligações covalentes.

d) forças dipolo-dipolo.

e) ligações de hidrogênio.

3. Os insetos mostrados na figura não afundam na água devido ao (a)

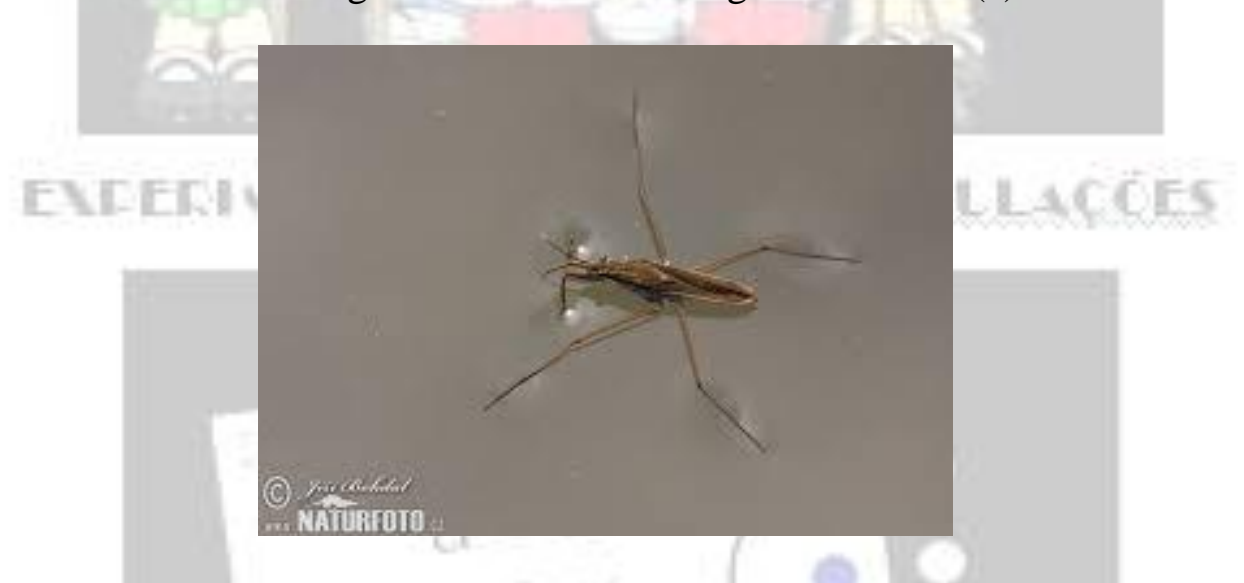

a) presença de pontes de hidrogênio, em função da elevada polaridade da molécula de água.

b) fato de os insetos apresentarem uma densidade menor que a da água.

c) elevada intensidade das forças de dispersão de London, em consequiência da polaridade das moléculas de água.

d) interação íon - dipolo permanente, originada pela presença de substâncias iônicas dissolvidas na água.

e) imiscibilidade entre a substância orgânica que recobre as patas dos insetos e a água. 4. (UFC - adaptado) Uma pesquisa publicada na revista Nature (Ano: 2000, vol.405, pg. 681,) mostrou que a habilidade das lagartixas (víboras) em escalar superfícies lisas como uma parede, por exemplo, é resultado de interações intermoleculares. Admitindo que a parede é recoberta por um material apolar e encontra-se seca, assinale a 
alternativa que classifica corretamente o tipo de interação que prevalece entre as lagartixas e a parede, respectivamente:

a) íon - íon.

b) íon - dipolo permanente.

c) dipolo induzido - dipolo induzido.

d) dipolo permanente - dipolo induzido.

e) dipolo permanente - dipolo permanente.

5. (UFC) As forças intermoleculares são responsáveis por várias propriedades físicas e químicas das moléculas, como, por exemplo, a temperatura de fusão. Considere as moléculas de $\mathrm{F}_{2}, \mathrm{Cl}_{2}$ e $\mathrm{Br} 2$.

a) Quais as principais forças intermoleculares presentes nessas espécies?

b) Ordene essas espécies em ordem crescente de temperatura de fusão.

\section{Referência}

BONI, Luis Alcides Brandini de; GOLDANI, Eduardo. Introdução Clássica à Química Geral. Ed.Tchê Química Cons. Educ. Porto Alegre, 2007.

FELTRE, Ricardo. Química Geral. Editora Moderna, 6 a edição, vol. 2. São Paulo, 2004. Forças intermoleculares. Disponível em < extensao.cecierj.edu.br/material_didático > . Acessado em 18/07/2015.

GOMES, Abílio Soares; CLAVICO, Etiene. Propriedades Físico - Químicas da água. Universidade Federal Fluminense, 2005. Disponível em: < www.uff.br/ecosed >. Acessado em 18/07/2015.

LISBOA, Julio Cesar Foschini. Química, $1^{\circ}$ ano: ensino médio. Editora SM Ltda, $1^{\mathrm{a}}$ edição, São Paulo, 2010.
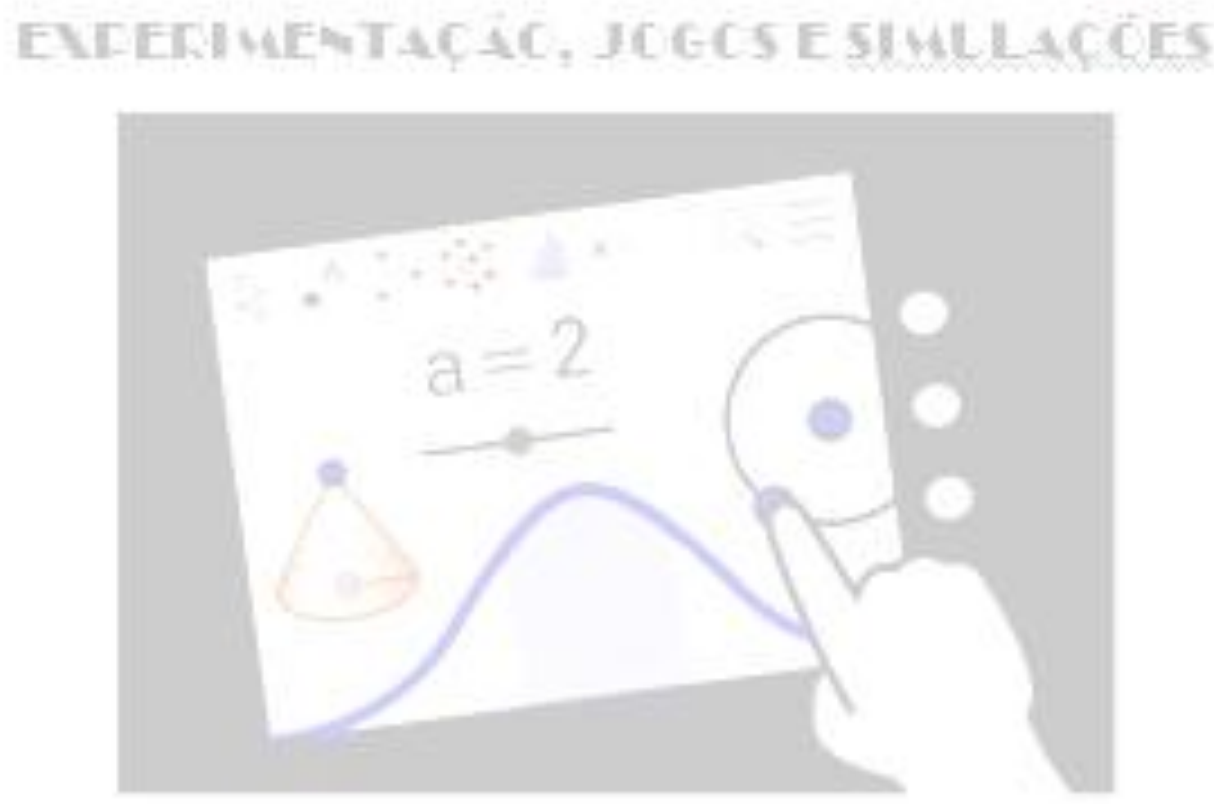


\title{
UFS - Mestrado em Ensino de Ciências e Matemática
}

\author{
Disciplina: O Ensino Experimental em Ciências Naturais
}

Autores: Vando Kebler Santos Soares

Docente: Luiz Adolfo de Mello

\section{Sequência Didática: Estudo De Associação De Resistores}

Aula 1 - Divisão da turma em grupos de 05 a 06 alunos. Dentre esses alunos, o grupo deverá eleger um coordenador e um secretário para organizar e registrar, respectivamente, o debate. Em seguida segue-se a apresentação da situação-problema utilizando a metodologia (passos) da Aprendizagem Baseada em Problemas (ABP): 1. Leitura da situação-problema; 2. Identificação e esclarecimento dos termos desconhecidos através de dicionário; 3. Identificação dos problemas; 4. Formulação e resumo de hipóteses para os problemas identificados; o grupo deve entregar por escrito ao professor os problemas identificados e as hipóteses que formularam. Pode-se compartilhar para todos os grupos os problemas identificados e hipóteses formuladas em cada grupo. 
Aula 2 - Experimento: montar um circuito elétrico utilizando fios, pequenas lâmpadas e pilhas ou a partir do simulador disponível em: https://phet.colorado.edu/pt BR/simulation/legacy/circuit-construction-kit-ac-virtual-lab, neste caso a aula deve ser realizada no laboratório de informática da escola, buscando visualizar a situação-problema apresentada e os problemas identificados ou, ainda, detectar possíveis problemas não registrados anteriormente;

Aula 3 - Aplicação do passo 5 da ABP: Formulação dos objetivos de aprendizagem para o tema estudado; caso os alunos listem parcialmente os objetivos, verifica-se se os grupos chegaram a objetivos diferentes e reunindo-os apresenta-os a toda turma. Caso os alunos não consigam listar todos os objetivos, isso não impede que seja sugerida a bibliografia para o estudo: o livro-texto, artigos, vídeos. Além das sugestões de leitura, os estudantes podem pesquisar sobre o tema abordado em outras fontes, como a internet. Essa 6a etapa (estudo/pesquisa) ocorre fora do momento da aula, em geral, de forma individual e em casa.

Aula 4 - Passo 7. Rediscutir a situação-problema à luz dos conhecimentos adquiridos com os estudos/pesquisas. Os alunos devem elaborar um roteiro de entrevista para ser feita com um especialista na área, por exemplo, um eletricista (Trabalho para ser entregue na aula seguinte). Aplicação de questionários avaliativos.

Aula 5 - Discutir as dúvidas que o aluno encontrou ao trabalhar a matemática envolvida nas associações por meio dos exercícios do livro-texto no seu estudo individual.

Observação: A seqüência apresentada foi planejada para um currículo de Física com duas aulas semanais de 50 min cada.

\section{Situação-problema para a seqüência didática sobre associação de resistores}

\section{"Fazendo ligações"}

João, depois de concluir a construção de sua casa, decidiu contratar um eletricista para fazer a instalação elétrica. Seu primo, José, se ofereceu para realizar o trabalho, embora não fosse eletricista profissional. José pediu a João que comprasse "cabinhos com diferentes $\mathrm{mm}$ de bitola", tomadas, interruptores, soquetes e lâmpadas. Concluído o serviço, João verificou que ao acionar um dos interruptores todas ou nenhuma das lâmpadas da casa acediam e, quando acendiam apresentavam alteração no brilho. 
Objetivos de aprendizagem:

- Relacionar a linguagem popular com a física;

- Diferenciar os tipos de circuitos elétricos (associação de resistores);

- Caracterizar o comportamento da resistência elétrica (resistência equivalente), da corrente elétrica e da tensão nos circuitos;

- Identificar como as características da fiação interferem nos circuitos elétricos, em particular, das instalações residenciais;

- Discutir a importância de ter a orientação e o trabalho de um profissional na área.

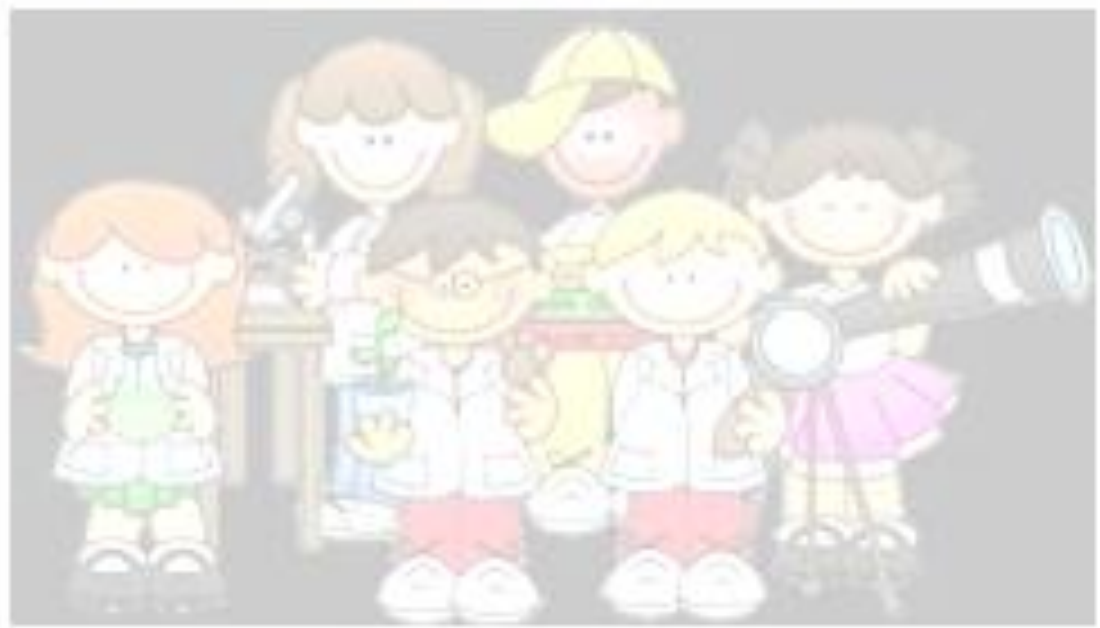

ENIERWEWTACAC, ICGCSESHWLLACCES

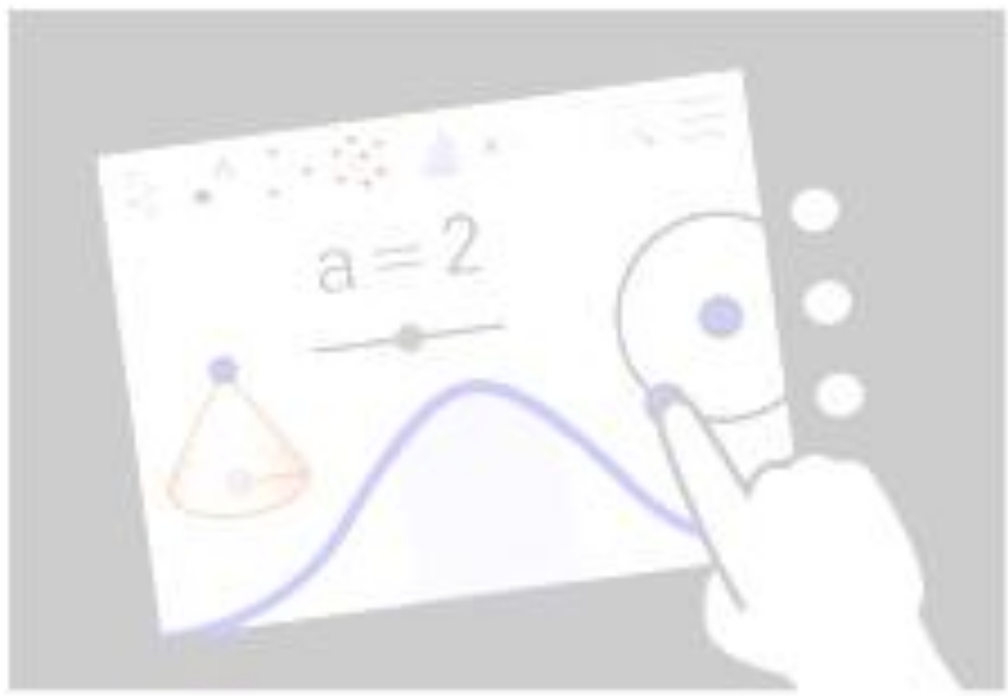




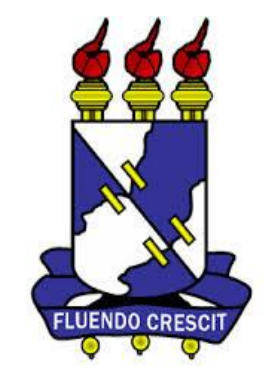

UNIVERSIDADE FEDERAL DE SERGIPE

\section{PROGRAMA DE PÓS GRADUAÇÃO EM ENSINO DE} CIÊNCIAS E MATEMÁTICA- PPGECIMA

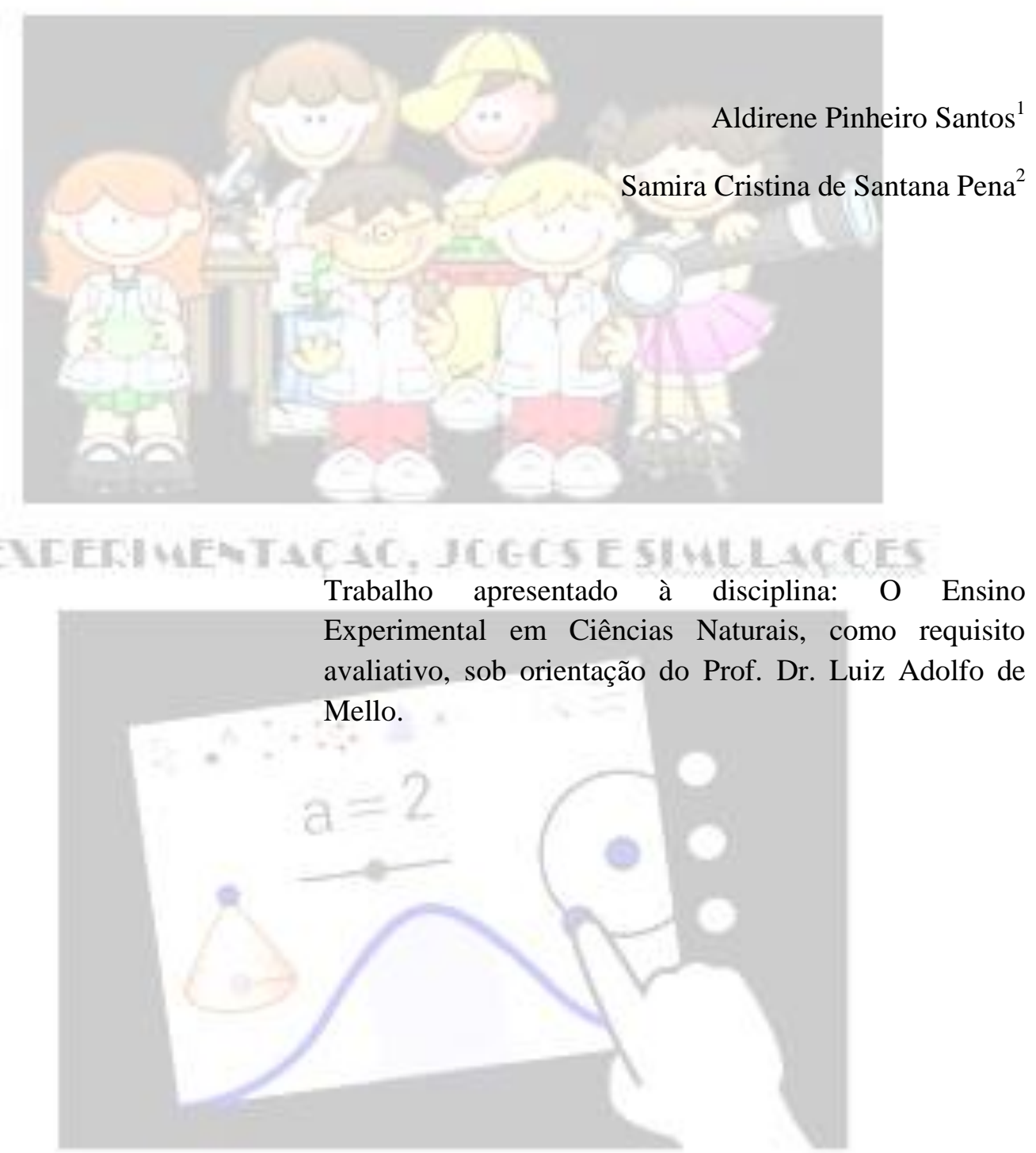

\footnotetext{
${ }^{1}$ Mestranda em Ensino de Ciências e Matemática (NPGECIMAUFS). quimicapinheiro@hotmail.com

${ }^{2}$ Mestranda em Ensino de Ciências e Matemática (NPGECIMAUFS). samiraspena@gmail.com
} 


\section{Plano de Aula- Ensino de Ciências}

Disciplina: Biologia

Público Alvo: Ensino fundamental II e/ou Ensino Médio

Duração: 50 minutos

Conteúdo: Fermentação (Processo fermentativo desenvolvido pelos fungos)

Objetivos Geral: Inserir o conteúdo de fermentação por meio de uma atividade experimental.

\section{Objetivos Específicos:}

$\checkmark$ Evidenciar o processo fermentativo desenvolvido pelos fungos

$\checkmark$ Associar a fermentação dos fungos com atividades cotidianas

\section{Sequência Didática:}

\section{Questionamentos iniciais:}

Primeiramente questionar os alunos sobre o que é fermentação e o que eles sabem sobre esse conteúdo, a fim de fazer o diagnóstico inicial, perguntar quais tipos de fermentação eles conhecem e como elas ocorrem.

\section{Apresentar o conteúdo:}

Apresentar uma síntese do que é fermentação, pois, a partir do experimento é que os alunos começarão a formar um conceito do que é de fato e de como ocorre a fermentação.

Síntese: A fermentação é um processo de liberação de energia que ocorre sem a participação do oxigênio (processo anaeróbio). A fermentação compreende um conjunto de reações enzimaticamente controladas, através das quais uma molécula orgânica é degradada em compostos mais simples, liberando energia. A glicose é uma das substâncias mais empregadas pelos microorganismos como ponto de partida na fermentação.

3. Experimento: Inflando o balão 
Para realização do experimento, será necessário: uma bexiga (ou labão de festa); 100ml de água morna; três colheres de fermento biológico (usado pata fazer pães, encontrado em supermercados e padarias); três colheres de chá de açúcar e uma garrafa de plástico, tipo pet, com capacidade para $500 \mathrm{ml}$.

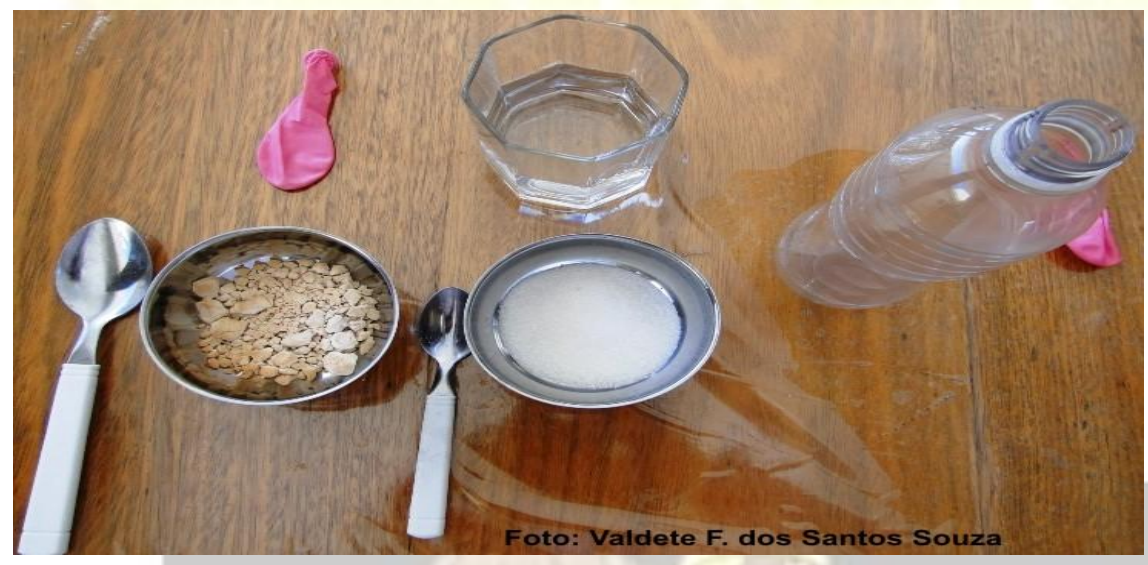

\section{Passo a passo do experimento:}

a. Cada aluno deverá receber os materiais descritos acima.

b. Cada aluno deverá construir um relatório durante a realização do experimento, registrando todas as etapas do processo e suas conclusões sobre ele.

c. Cada aluno deverá colocar o açúcar e o fermento dentro da garrafa pet, em seguida adicionar água morna.

d. Colocar a bexiga na boca da garrafa par vedar e aguardar até que a bola infle (isso deverá ser identificado pelos alunos).

\section{Após o experimento:}

Discutir com os alunos:

O que encheu os balões de festa?

Por que isso ocorreu?

De que forma esse fenômeno ocorre na natureza?

Qual sua importância?

Por que é importante saber esse conteúdo e relacioná-lo com a vida cotidiana?

\section{Discussões finais:}

Após discutir com os alunos as questões anteriores, o professor deve conduzir a aula no sentido de relacionar os processos de fermentação com atividades cotidianas, como: fazer pão, bolos, cerveja e etc. exaltando a necessidade de 
conhecer e saber este conteúdo para a vida. Deve apresentar os tipos de fermentação, como ocorrem e as substâncias envolvidas no processo.

\section{Avaliação:}

Processual e análise dos relatórios produzidos pelos alunos.

\section{REFERÊNCIAS}

CIÊNCIAS. Valdete. Experiência inflando balão. Acesso em 26 de jun. de 2015. Disponível em: <http://valdeteciencias.blogspot.com.br/2011/09/no-dia-13092011-osalunos-da-6-serie-e.html>

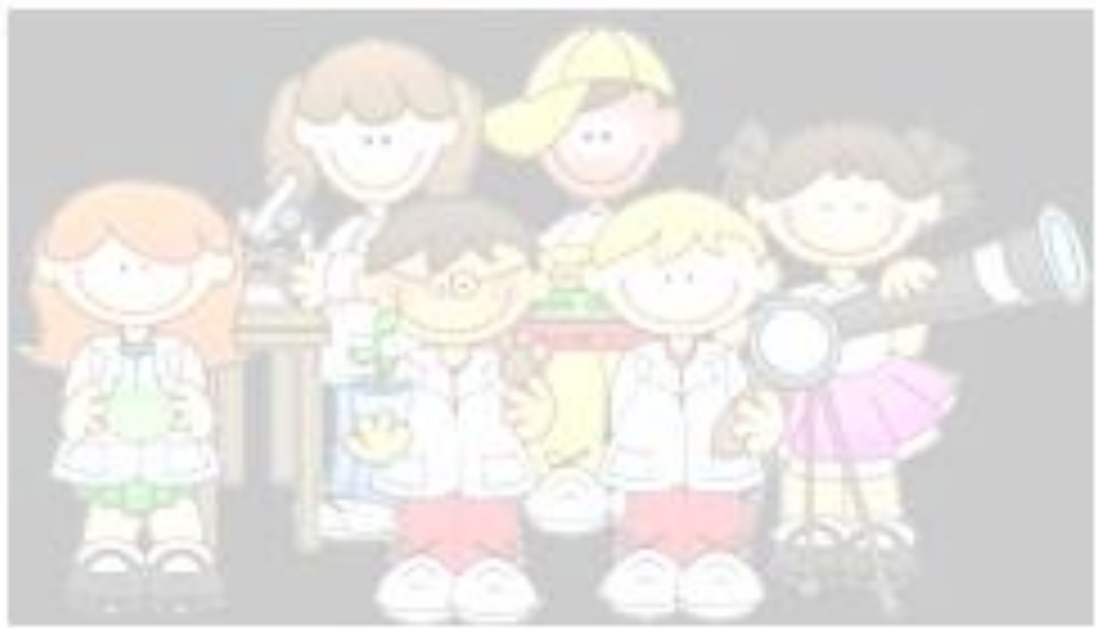

EXIERWWEWTACAC, ICGCS ESHWLACOES

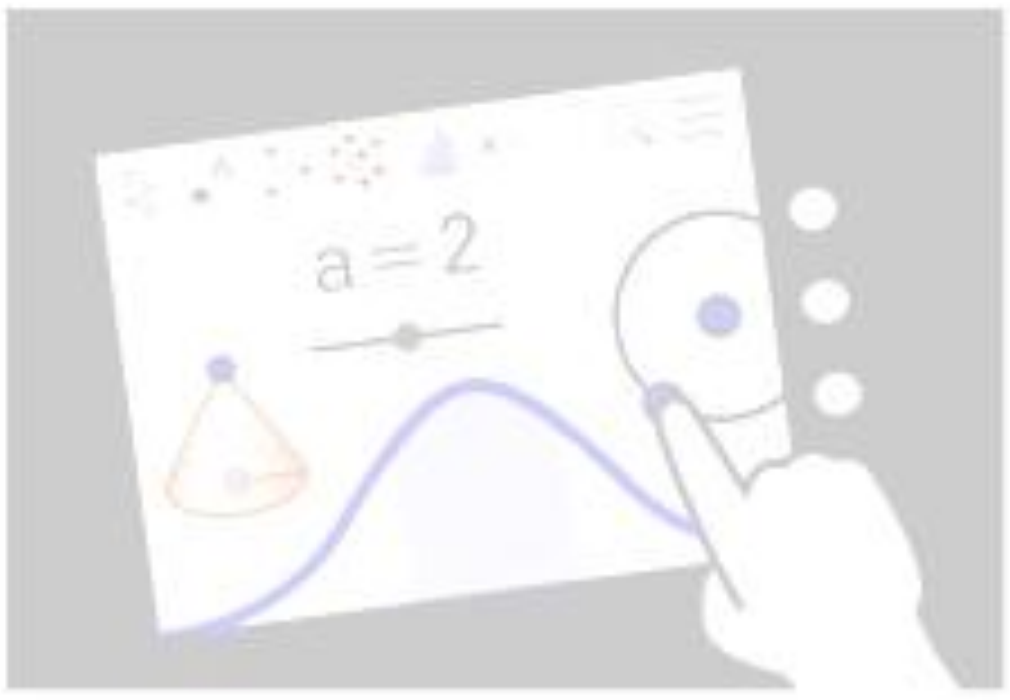

